Exporting Pollution: Where Do Multinational Firms Emit $\mathrm{CO}_{2}$ ?

Itzhak Ben-David, Stefanie Kleimeier, and Michael Viehs

NBER Working Paper No. 25063

October 2018, Revised in September 2020

JEL No. N50,O13,P18,Q56,R11

\begin{abstract}
$\underline{\text { ABSTRACT }}$
Despite widespread awareness of the detrimental impact of $\mathrm{CO}_{2}$ pollution on the world climate, countries vary widely in how they design and enforce environmental laws. Using novel microdata about multinational firms' $\mathrm{CO}_{2}$ emissions across countries, we document that firms headquartered in countries with strict environmental policies perform their polluting activities abroad in countries with relatively weaker policies. These effects are largely driven by tightened environmental policies in home countries that incentivize firms to pollute abroad rather than lenient foreign policies that attract those firms. Although firms headquartered in countries with strict domestic environmental policies are more likely to export pollution to foreign countries, they nevertheless emit less overall $\mathrm{CO}_{2}$ globally.
\end{abstract}

Itzhak Ben-David

The Ohio State University

Fisher College of Business

606A Fisher Hall

Columbus, OH 43210-1144

and NBER

ben-david.1@osu.edu

Stefanie Kleimeier

Maastricht University

School of Business and Economics

Open Universiteit

Faculty of Management, Science \& Technology

and University of Stellenbosch Business School

s.kleimeier@maastrichtuniversity.nl
Michael Viehs

University of Oxford

Smith School of Enterprise and

the Environment and

Hermes Investment Management

150 Cheapside

London EC2V 6ET

United Kingdom

michael.viehs@gmail.com 


\title{
Exporting Pollution: Where Do Multinational Firms Emit $\mathrm{CO}_{2}$ ?
}

\author{
Itzhak Ben-David \\ Fisher College of Business, The Ohio State University, and NBER \\ Yeejin Jang \\ School of Banking and Finance, University of New South Wales \\ Stefanie Kleimeier \\ School of Business and Economics, Maastricht University, Faculty of Management, \\ Open Universiteit, and University of Stellenbosch Business School \\ Michael Viehs \\ European Center for Sustainable Finance (ECCE) \\ and Federated Hermes International
}

August 2020

\begin{abstract}
Despite widespread awareness of the detrimental impact of $\mathrm{CO}_{2}$ pollution on the world climate, countries vary widely in how they design and enforce environmental laws. Using novel microdata about multinational firms' $\mathrm{CO}_{2}$ emissions across countries, we document that firms headquartered in countries with strict environmental policies perform their polluting activities abroad in countries with relatively weaker policies. These effects are largely driven by tightened environmental policies in home countries that incentivize firms to pollute abroad rather than lenient foreign policies that attract those firms. Although firms headquartered in countries with strict domestic environmental policies are more likely to export pollution to foreign countries, they nevertheless emit less overall $\mathrm{CO}_{2}$ globally.
\end{abstract}

Keywords: Pollution, Production, Climate Change, $\mathrm{CO}_{2}$ Emission, Environmental Regulation JEL Classification: F23, N50, O13, P18, Q56, R11

\footnotetext{
* We are grateful to CDP (Carbon Disclosure Project) for sharing the climate-change data with us. All views expressed in this paper are those of the authors and not necessarily those of the international business at Federated Hermes or EOS at Federated Hermes. Ben-David is a co-founder and a partner in an investment advisor that manages investment accounts.
} 


\section{$1 \quad$ Introduction}

As signs of climate change accumulate, countries around the globe are taking action, yet there is considerable variation in the strictness of the environmental policies implemented. ${ }^{1}$ Diversity and lack of coordination in regulations across countries can lead to "carbon leakage," meaning that firms decide strategically where to locate their production based on existing environmental policies.

Given the heterogeneity in environmental policies across countries, the behavior of multinational firms is especially important for two main reasons. First, the cost of shifting polluting activities abroad for multinational firms is low relative to the cost that would be incurred by purelydomestic firms, as they can utilize existing infrastructure. Second, multinational firms are an important segment of the global economy; for example, cross-border investment by multinational firms contributed 50\% of GDP of OECD countries in 2017 (Navaretti and Venables, 2013; Shapiro and Hanouna, 2019). ${ }^{2}$ Despite their economic importance, little is known about the extent to which multinational firms allocate polluting activities around the globe in response to environmental policies. Understanding the symbiotic relationship between countries' environmental policies and the production decisions of multinational firms would help policymakers and governments effectively address the emerging challenges from climate change.

In this article, we study the impact of environmental policies on multinational firms' polluting activities at home or in foreign countries in the $2010 \mathrm{~s} .{ }^{3}$ We use firm-level data about

\footnotetext{
${ }^{1}$ For example, the European Commission announced in December 2019 a 30-year plan to transit toward a climateneutral economy by 2050, called the European Green Deal, and proposed to enact climate law. Other countries, however, are maintaining laxer regulations and failing to meet lower carbon dioxide $\left(\mathrm{CO}_{2}\right)$ emissions targets set forth in the Paris Agreement of 2015, designed to collectively combat climate change (United Nations Environment, 2019). Still others are considering withdrawing from the Paris Agreement altogether. The U.S. government announced that the country would pull out of the Paris Agreement, and in November 2019, it submitted formal notification of its withdrawal to the United Nations. The Australian government resisted taking action to increase the 2030 target for $\mathrm{CO}_{2}$ emissions even after catastrophic bushfires in early 2020.

${ }^{2}$ The statistics are based on the outward foreign direct investment positions (stocks), as a percentage of gross domestic product (GDP), at 2017 year-end for OECD countries. See the OECD International Direct Investment Statistics (database) at https://doi.org/10.1787/idi-data-en.

${ }^{3}$ Other studies, such as Kim, Wan, Wang, and Yang (2019), explore the causal relation between changes in environmental policies and firm response. Due to constraints related to tight identification, these studies tend to focus on specific episodes and therefore have limited geographical and temporal scope.
} 
their carbon dioxide $\left(\mathrm{CO}_{2}\right)$ emissions in each country. ${ }^{4}$ Together with information about the country-level environmental regulations and enforcement, we assess the impact of home versus foreign environmental policies on firms' pollution allocations. Our findings indicate that the allocation of pollution activities is primarily driven by the environmental policies in the home country rather than by the opportunities available to pollute elsewhere. Our findings highlight the importance of collective action to combat climate change given the global scale of firms' operations.

We use a novel panel dataset covering 1,970 large public firms headquartered in 48 countries and their $\mathrm{CO}_{2}$ emissions in 218 countries during the 2008-2015 period. The unique feature of our dataset is that we can separately observe the $\mathrm{CO}_{2}$ emissions of each multinational firm in each country in which it operates, providing direct evidence on the effect of environmental policies and firms’ actual $\mathrm{CO}_{2}$ emissions at the micro-level.

In the main analysis, we explore the location of pollution activities with respect to countries' environmental policies. Using a firm-year panel, we document that firms headquartered in countries with stricter environmental policies emit less $\mathrm{CO}_{2}$ both domestically and globally relative to firms headquartered in countries with more lenient environmental regulation. However, we find evidence of carbon leakage from countries with strict environmental policies: Stricter domestic environmental policies are associated with a greater share and greater amounts of pollution abroad. The effects are economically large: A one-standard-deviation increase in the strictness of environmental policies in the home country is associated with a $29 \%$ reduction of $\mathrm{CO}_{2}$ emissions at home, but it is also associated with up to a $43 \%$ increase in emissions abroad. These results lend support to the concern that strict environmental policies may lead to carbon leakage. While strict national environmental policies are effective in reducing global $\mathrm{CO}_{2}$ emissions to a certain extent, they also create negative externalities, incentivizing firms to export their polluting activities to other countries. Given the relative scale of foreign operations, however, our analysis suggests that stringent domestic environmental policies still have a partial, but positive, impact on reducing overall pollution. A one-standard-deviation increase in the strictness of environmental

\footnotetext{
${ }^{4}$ Although several greenhouse gases contribute to climate change, we focus on $\mathrm{CO}_{2}$, a byproduct of industrial production that has the fastest concentration growth in the atmosphere. For further information, see https://www.ucsusa.org/global-warming/science-and-impacts/science/CO2-and-global-warming-faq.html.
} 
policies leads to about $14 \%$ lower global $\mathrm{CO}_{2}$ emissions, which is equivalent to a reduction of 441,000 tons of $\mathrm{CO}_{2}$ emission annually by an average multinational firm.

Next, we explore the destination countries to which firms export their pollution. Specifically, we examine whether the difference in policy strictness between the home and the foreign country can predict whether and the extent to which such exporting takes place. Using a firm-country-year panel, we test whether the relative strictness of environmental policies in the home country versus the foreign country is correlated with more pollution abroad. Indeed, we find that firms pollute more in a foreign country when the difference in the strictness in environmental policies between the home and the foreign country is greater.

The results thus far are consistent with the pollution haven hypothesis, suggesting the firms perform their polluting activities in countries with lenient environmental policies. Prior studies that examined this hypothesis were based on limited data, e.g., aggregated at the industry or country levels, or lacked actual emissions data. ${ }^{5}$

Our data allow us to dive deeper into the drivers of carbon leakage. Specifically, a combination of both push and pull forces can explain our baseline results of carbon leakage. The push is in evidence when firms export their polluting operations to foreign countries in response to tightened environmental regulations in their home countries. The motivation for this move is purely economic because complying with stricter environmental policies is costly, requiring investment in resources such as waste treatment, auditing, and litigation (see, e.g., Christainsen and Haveman, 1981; Stewart, 1993). The pulling force is in action when countries deliberately impose relatively weak environmental policies to attract the economic activity of polluting firms. Such countries may benefit, at least in the short run, from the economic growth that additional industrial production would likely bring through employment and investment.

Our analysis shows that the main force dictating multinationals' emission of $\mathrm{CO}_{2}$ abroad is pressure from the home country's environmental policies (push force). First, we test the "push

\footnotetext{
${ }^{5}$ Earlier studies used limited data aggregated at the industry- or country-levels (e.g., Eskeland and Harrison, 2003; Cole, 2004; He, 2006; Wagner and Timmins, 2009). Related firm-level studies also provide indirect evidence, without observing actual pollution levels, that firms are more likely to have facilities in countries with weak environmental policies (Becker and Henderson, 2000, 2001; Ben Kheder and Zugravu, 2012; Dam and Scholtens, 2012). A few recent studies use actual $\mathrm{CO}_{2}$ emissions data, but the scope of these studies is limited - within specific countries or industries (e.g., Ederington, Levinson, and Minier, 2005; Bento, Freedman, and Lang, 2015; Bartram, Hou, and Kim, 2019).
} 
hypothesis.” We use a specification that holds constant the environmental policies of foreign countries to test whether changes in the environmental policies in the home country have an effect (as in Khwaja and Mian, 2008). Indeed, we find evidence of such a "push effect”: Tightening the home countries' environmental policies pushes multinational firms out and incentivizes them to pollute in foreign countries. Second, we reverse the specification and test the "pull hypothesis." We hold constant the home country environmental policies and test whether changes in the foreign country environmental policies matter for pollution abroad. We find no evidence supporting the pull hypothesis. In sum, multinational firms pollute abroad because of the tightening of policies in the home countries, not because of pollution opportunities abroad.

We also find that changes in environmental policies have asymmetric effects on firms' polluting behavior. While the tightening of policies forces firms to shift polluting activities abroad and to substitute with $\mathrm{CO}_{2}$ emissions through their supply chains (e.g., outsourcing), the relaxation of environmental policies in the home country does not affect the allocation of $\mathrm{CO}_{2}$ emissions. This finding suggests that tightening domestic environmental policies may create negative externalities in the absence of global coordination in curbing multinational firms' polluting activities.

In our final analyses, we exploit the cross-section of firms to examine the factors that amplify firms' incentives to pollute abroad in response to strict environmental policies at home.

First, we consider firm-level governance. For firms that have strong governance, we find that the positive effect of strict regulations on pollution is more pronounced. In other words, when the home country sets strict environmental policies, well-governed firms produce fewer emissions domestically and export fewer emissions to foreign countries. Importantly, this result could imply that strong governance mechanisms guide managers to consider long-term value, providing a counterweight that pushes the firm toward production with lower emissions (see Krueger, 2015, as well as the Dupont case in Shapira and Zingales, 2017). ${ }^{6}$

\footnotetext{
${ }^{6}$ The pressure to implement sustainable production techniques is generally associated with long-term investors who value corporate responsibility practices (see, e.g., the survey regarding institutional investors' perceptions of climate risks in Krueger, Sautner, and Starks, 2020, and Bonnefon, Landier, Sastry, and Thesmar, 2019). Consistent with institutional investors valuing firm environmental profiles, Kim, Wan, Wang, and Yang (2019) empirically document that firms mostly held by investors with socially responsible investing (SRI) styles tend to adopt environment-friendly corporate policies and eventually release fewer toxic chemicals.
} 
Second, we consider the variation of pollution by industry. Polluting activities vary widely by industry, and therefore we conduct a cross-sectional analysis by industry type. We document that firms' behavior with respect to environmental policies is more accentuated in pollutionintensive industries. The emissions in the home country of firms in these industries is less sensitive to home environmental policies; however, their emissions abroad are twice as sensitive to home policies, relative to firms in other industries. This finding is consistent with the idea that complying with strict environmental policies is particularly costly for pollution-intensive industry firms.

Overall, our study informs the debate among regulators as well as economists about the effectiveness of environmental policies in reducing pollution and their economic consequences. For regulators, our findings on multinational firms' $\mathrm{CO}_{2}$ emissions patterns in response to the stringency of countries' environmental policies highlight the need for global coordination of regulations on carbon dioxide emissions. We find that firms increase their pollution abroad in response to the tightening of environmental policies in their home countries, as opposed to being attracted by lax policies abroad. Thus, our results imply that without collective action, multinational firms with production facilities around the globe may continue to benefit from regulatory arbitrage opportunities by exporting pollution. At the same time, this study emphasizes that local policies restricting pollution activities do have some effect on reducing global pollution levels.

\section{$2 \quad$ Data Description and Summary Statistics}

\section{$2.1 \quad \mathrm{CO}_{2}$ Emissions Data}

Our main data source is a large database provided by CDP (formerly known as the Carbon Disclosure Project) that contains firms' self-reported survey responses about their national and global $\mathrm{CO}_{2}$ emissions. $\mathrm{CDP}$ is a UK-based "not-for-profit charity that runs the global disclosure system for investors, firms, cities, states, and regions to manage their environmental impacts” (CDP, 2020). As of August 2020, more than 500 institutional investors with more than US\$100 trillion in assets under management (AUM) were supporting CDP and its initiatives. Since CDP's inception in 2000, the number of institutional investors that have become signatories of CDP has grown tremendously as has the AUM represented by those investors. CDP began by only surveying 
UK-based FTSE firms but now obtains climate change and pollution information from firms around the world.

Our dataset consists of annual survey data from firms between 2008 and 2015. Over this period, CDP increased its outreach from about 3,000 to more than 6,000 firms worldwide. CDP sends its survey to the largest firms in the world, most of which have publicly-traded equity. The questionnaires ask firms about their $\mathrm{CO}_{2}$ emissions, their various approaches to combatting climate change, and the practices they use to manage potential risks stemming from climate change. In this study, we focus on the questions that ask firms about the $\mathrm{CO}_{2}$ emissions that stem both directly and indirectly from their operations. The answers to these questions allow us to directly measure firm-level emissions and identify the countries where these emissions take place. Overall, the firms in our sample emit $\mathrm{CO}_{2}$ in 218 different countries. We have pollution information on firms that operate in multiple countries as well as firms that operate in a single country (about $11 \%$ of the sample). We create a panel dataset containing annual $\mathrm{CO}_{2}$ emissions information for firms in each country in which they operate.

We have two main measures and one secondary measure of $\mathrm{CO}_{2}$ emissions. Scope 1 emissions are the total $\mathrm{CO}_{2}$ emissions (in metric tons) that stem directly from the operations of the reporting firms. Scope 2 emissions are the total $\mathrm{CO}_{2}$ emissions (in metric tons) arising from the production of the electricity the firm purchases to run its operations and over which it does not have direct influence. The firm estimates this quantity based on a breakdown of the electricity sources used in the respective country. Hence, Scope 2 measures emissions that take place upstream in production lines. Another category of $\mathrm{CO}_{2}$ emission is Scope 3, which measures other indirect emissions such as outsourced activities, business trips, and the production from suppliers in the supply chain. Scope 3 emissions data provided by CDP covers a subset of firms during the 2009-2013 period and are only available at the aggregate level. While we cannot use this information in our main analyses due to these data limitations, in Section 4.3 we use the Scope 3 data to shed light on the global substitution effect along supply chains.

Note that our data are based on firms' self-reported information. Specifically, CDP collects data that firms voluntarily provide in response to a survey. Despite the self-reported nature of our data, we believe that the emissions information is accurate and close to actual emissions for several reasons. First, firms' incentive to report their emissions comes from pressure from both 
institutional investors and regulators who demand greater transparency about the environmental impacts of their business and how climate change affects the long-run viability of the business. Investors, especially long-term institutional investors such as pension funds and insurance companies, seek to understand the long-run implications of tightening climate change and environmental regulations resulting from the Paris Agreement on climate change, which was agreed upon at the end of 2015 and subsequently has begun to be implemented by most signatory countries. In addition, institutional investors are interested in learning about firms' exposure to climate change and environmental issues to identify business models that are at risk or less resilient. The consequences of misreporting can be detrimental for multinational firms that rely on institutional investment. Second, prior research shows that firms report emissions rates that are at least as high in their sustainability reports (like CDP) as in their annual financial reports (Depoers, Jeanjean, and Jérôme, 2016). Finally, a self-reporting bias is likely to attenuate results against finding supporting evidence that firms in tightly regulated countries are more likely to export pollution. Firms might under-report their emissions activity in foreign countries. If anything, our results are likely to show a lower bound for the effect, because pollution reporting is voluntary and the reporting firms may be less aggressive than non-reporters.

To address the concern that self-reporting may affect our results, we repeat some of the tests using a subset of firms that report audited data. Specifically, investors of some firms have begun requiring their auditors to approve the statistics in the sustainability reports. We have information on whether firms had their auditors verify the $\mathrm{CO}_{2}$ information and which reporting standard they applied. ${ }^{7}$ In Section 5.4, we use this fact to provide some assurance regarding the quality of the data and hence the results. ${ }^{8}$

\footnotetext{
${ }^{7}$ The CDP data contain information on how and to what extent the firms' auditors or other third parties have verified the reported carbon emissions. The dataset also contains information about what reporting standard or framework was applied to verify the carbon emissions, such as, for example, ISO14064-3. Furthermore, companies usually disclose in their annual reports or sustainability reports whether their reported information on carbon emissions has been verified and, if so, by whom.

${ }^{8}$ When we restrict the sample to those observations for which the emissions information has been verified by external parties such as the firms' auditors, the main results are quantitatively similar to those obtained using the full sample. We discuss these robustness tests and results in Section 5.4.
} 


\subsection{Country-Level Data: Environmental Laws, Enforcement, and Macroeconomic} Conditions

We use an additional dataset compiled by the World Economic Forum (WEF) that contains information about the strictness of environmental laws and enforcement at the country-year level. This dataset covers the 2008-2015 period and is publicly available on a bi-annual basis for 150 countries. ${ }^{9}$ WEF assigns two rankings for each country on a scale from 1 to 7 : (1) the stringency of its environmental regulation (SER) and (2) how strictly these laws are enforced (EER), based on surveys of top local business leaders. ${ }^{10}$ The profile of the survey respondents increases the validity of our results, because the WEF measure reflects scores as perceived by corporate leaders, who eventually respond to this perception by determining the location of polluting activities. The two environmental policy measures-stringency of environmental regulation and stringency of enforcement-are highly correlated (correlation coefficient of 0.97).

For our analysis, we combine the two policy measures into a single measure. We assume that a country needs both components, laws and enforcement, to have a robust environmental policy in place. Stated differently, an inherent interaction exists between these two dimensions: Strict environmental laws must be enforced to make a difference. Because of the high correlation of these variables, introducing both into the regression simultaneously induces severe multicollinearity. To remedy this issue, we adopt three approaches. The first is to combine the two scores into a single variable: $S E E R=\frac{1}{7} S E R \times E E R$. We call this measure stringency and enforcement of environmental regulation, or SEER, and its value ranges from 0.14 to 7 . The other two approaches involve examining the effect of each variable in isolation and orthogonalizing the variables so that we can introduce both into the regressions. We implement these approaches as a robustness test in Section 5.3. Overall, our results largely remain robust across the three methods.

\footnotetext{
${ }^{9}$ See Travel \& Tourism Competitiveness Reports of WEF, e.g., https://www.weforum.org/reports/the-travel-tourismcompetitiveness-report-2017.

${ }^{10}$ We use annual rankings from the WEF's Executive Opinion Survey administered to more than 14,000 business leaders worldwide. Two survey questions are relevant to our study: (1) How would you assess the stringency of your country's environmental regulations? and (2) How would you assess the enforcement of environmental regulations in your country? Answers range from 1 (very lax) to 7 (among the world's most rigorous). According to the WEF, its survey "captures the opinions of business leaders around the world on a broad range of topics for which data sources are scarce or, frequently, nonexistent on a global scale. It helps to capture aspects of a particular domain ... that are more qualitative than hard data can provide” (Schwab and Sala-i-Martin, 2016). The WEF survey measures are highly correlated with policy-based indices such as the EBRD's CLIMI index or the OECD's EPS index (Botta and Koźluk, 2014) but have the advantage of being available for a large number of countries over time.
} 
To consider macroeconomic conditions of the countries in which firms operate, we collect information on GDP and GDP per capita growth from the World Bank's World Development Indicators. We also estimate the industry-level comparative advantage in skilled labor and capital of each country - CA(Skill) and CA(Capital), respectively — following Romalis (2004) and Nunn (2007). ${ }^{11} \mathrm{CA}$ (Skill) is defined as $h_{s} H_{c}$, and CA(Capital) is defined as $k_{s} K_{c} . H_{c}$ and $K_{c}$ denote endowment in skilled labor and capital in country $c$, respectively. $h_{s}$ and $k_{s}$ denote the skill and capital intensities of production in the firm's industry s. ${ }^{12}$ Skill intensity $h_{s}$ is the ratio of nonproduction worker wages to total wages in industry $s$ in the United States, averaged across the period 2008 to 2011. Capital intensity $k_{s}$ is the real capital stock in industry $s$ divided by the value added in industry $s$ in the United States, averaged across the period 2008 to 2011. A country's skilled labor endowment $H_{c}$ is measured as the natural log of the ratio of the population aged 25 or above that completed secondary education to those that did not complete secondary education. ${ }^{13}$ A country's capital endowment $K_{c}$ is the natural log of the capital stock per worker, averaged across the period 2008 to $2015 .{ }^{14} \mathrm{We}$ also collect country-pair proxies such as geographical distance, common border, colonial history, and logged annual trade between the firm's home country and the country in which it emits $\mathrm{CO}_{2}$. These proxies come from Andrew Rose's website (see Glick and Rose, 2016) and the International Monetary Fund's Direction of Trade Statistics.

\subsection{Firm-level Financial Data}

We obtain firm-specific financial information, including total assets and foreign asset share, from Worldscope. As our measure of the corporate governance quality of firms, we use the corporate governance score provided in the Thomson Reuters Asset 4 database (CGVSCORE). This firm-year dataset is widely used in academic research as well as by long-term institutional investors interested in environmental, social, and governance information. The governance score ranges from 0 to 100 and measures as a percentage the quality of a firm's governance systems and

\footnotetext{
${ }^{11}$ Skilled labor and capital endowment data are not available for all countries and factor intensities are only available for manufacturing industries. Consequently, our sample size drops substantially.

12 Data for factor intensities are obtained from the NBER-CES Manufacturing Industry Database available at http://data.nber.org/nberces/, which contains annual data up to 2011.

${ }^{13}$ Data for skilled labor endowment $H_{c}$ are obtained from the Barro-Lee Educational Attainment Dataset, available at http://barrolee.com/. Data for 2010 are used as this is the only year that falls into our sample period.

14 Data for capital endowment $K_{c}$ are obtained from the Penn World Tables, available at https://www.rug.nl/ggdc/productivity/pwt/.
} 
processes, ranging from board structure and compensation arrangements to a firm's treatment of shareholder rights. A higher CGVSCORE value indicates better governance. All variable definitions and sources can be found in Appendix Table 1.

The final dataset that we construct is a three-dimensional panel of the firm-country-year that contains the amount of $\mathrm{CO}_{2}$ emissions by each firm in each country in each year. Naturally, most of our emissions observations have a value of zero because firms tend to have operations in a limited set of countries. ${ }^{15}$

\subsection{Summary Statistics}

\subsubsection{Trends in Pollution and Environmental Policies}

Table 1 reports summary statistics over the sample period of 2008 to 2015, including the number of unique firms, their global and home-country emissions, and the number of countries in which each firm has emissions. For the average firm, global Scope 1 and Scope 2 emissions in tons decrease over time. Note that the majority of emissions are direct Scope 1 emissions. One caveat of interpreting the average firm-year emissions, however, is that these trends can be a result of the expanding coverage of firms by CDP (see Section 3.3 for a discussion of time trends of emissions). Most $\mathrm{CO}_{2}$ is emitted domestically, but the share of home emissions in global emissions decreases substantially over time (from $72 \%$ in 2008 to about 57\% in 2015 for Scope 1 emissions). In addition, the number of countries where the average firm's emissions take place increases from 6.0 (6.8) countries in 2008 to 9.0 (10.6) in 2015 for Scope 1 (Scope 2).

As described earlier, our measure of environmental regulation is SEER, which is the product of measures of the environmental strictness score (ranging from 1 to 7 ) and the environmental enforcement score (ranging from 1 to 7), scaled by 7. Panel C of Table 1 indicates that SEER slightly increases over time, both on average and at the median, with most of the improvement occurring among the 50 countries that had the weakest environmental policies in 2008. The statistics suggest that environmental regulation has tightened over time, but the crosscountry variation is much starker than the time-series variation within a country. Furthermore, we

\footnotetext{
${ }^{15}$ Not all firms fully disaggregate their global emissions to the country level. We thus impose a minimum disaggregation requirement and restrict our sample to firms that report at least $85 \%$ of their global emissions on a country level.
} 
observe that the distribution of environmental regulation is skewed, with most countries being weakly regulated.

Environmental regulation varies greatly around the globe. Figure 1 uses heat maps to show country-level environmental regulation at the beginning and end of our sample period (2008 and 2015). The map shows a general improvement in environmental regulation over time; however, it remains weak in several large regions, especially in developing countries in Africa, South America, and Asia.

As environmental regulations have, on average, tightened globally in recent years, it is important to examine how polluting activities have evolved over time. To understand the trend of the overall amount and allocation of $\mathrm{CO}_{2}$ emissions by multinational firms in our sample, we estimate ordinary least squares (OLS) regressions with time fixed effects, using the sample of firmyear emissions observations. The dependent variables include the $\mathrm{CO}_{2}$ emissions variables. In addition to year indicators, we include firm fixed effects in the regressions to address any potential sample bias from the increase in coverage of firms by CDP. Thus, the coefficients of the year dummy variables indicate the incremental changes in emissions over time (2008 as a baseline) after controlling for any firm-level unobservable factors that might be correlated with being included in the CDP dataset.

In Figure 2, we plot the point estimates and 95\% confidence intervals of year indicators for global, home, and foreign emissions, and the percentage of foreign emissions. In Panel A, we observe a rise in global emissions in 2010; thereafter, global emissions remain relatively constant. However, the percentage of foreign emissions increases over time. Panel B, which focuses on the allocation of pollution between home and foreign countries, clearly confirms this pattern. We find that firms continuously increased the percentage of pollution they export to foreign countries from 2008 to 2015 while moderately reducing pollution at home. These figures imply that global carbon emissions by firms neither increased nor decreased substantially during the study period, but carbon leakage became more prevalent. 


\subsubsection{Relationship between Environmental Regulation and $\mathrm{CO}_{2}$ Emissions}

Figure 3 presents a visualization of the relation between environmental regulation in the firm's home country (as measured by our proxy SEER) and firm-level emissions abroad. We plot each country as a circle, the size of which represents the average home emissions by firms in that country (in tons). The color of the circle indicates the stringency of environmental regulation scores (SEER) in the home country, with the scale from red (the weakest regulation) to green (the most stringent regulation). The $y$-axis shows the average percentage of emissions in foreign countries. Two observations can be made. First, the size of the circles is much smaller in green countries than in red countries, suggesting that strict regulations in home countries are negatively associated with the amount of home emissions. Second, the slope of the dotted predictive line implies that firms headquartered in strictly regulated countries produce a higher proportion of their $\mathrm{CO}_{2}$ emissions abroad than domestically.

\subsubsection{Firm-level Summary Statistics}

Table 2 presents summary statistics for our sample firms. It shows that, on average, firms emit more in their home countries than abroad (1.85 million tons vs. 1.30 million tons for Scope 1 emissions and 0.37 million tons vs. 0.30 million tons for Scope 2 emissions). On average, 38.3\% (42.8\%) of firms' Scope 1 (Scope 2) emissions are emitted abroad. These ratios are slightly higher-41.4\% for Scope 1 and $44.8 \%$ for Scope 2 - when we take the value-weighted average, using the amount of global emissions as weights. The average SEER for a firm in our sample is 4.11; the average score for the strictness of environmental regulation is 5.43; and the average score for the enforcement of environmental regulation is only 5.23. The firms covered in our sample are mostly large multinational firms with an average of US\$60.7 million in assets and a foreign asset share of $26.4 \%$. Panel B of Table 2 provides additional country-level statistics that we use in our empirical analyses as control variables. 


\section{$3 \quad$ Empirical Design and Main Results}

\subsection{Polluting Domestically or Abroad?}

To test whether firms pollute more in countries with weak environmental policies, we estimate the following equation:

$$
y_{i t}=\beta_{1} S E E R_{\text {home }}+\beta_{2} \text { Controls }+\sigma_{s t}+\varepsilon_{i t} .
$$

The following dependent variables measure the amount of pollution by firm $i$ in year $t$ : logged global emissions of $\mathrm{CO}_{2}$, logged emissions in the home country, logged total emissions in all foreign countries, and total foreign emissions as a percentage of global emissions. ${ }^{16}$ Our main variable of interest is SEER, the combined variable of environmental policy and enforcement strictness in the firm's home country $(h)$ in year $t$. We include as control variables logged firm assets, the share of foreign assets, and logged GDP in the home country. In addition, to capture any industry-specific trends in emissions that might confound the changes in country-level regulations targeting specific industries, we include industry-year $\left(\sigma_{s t}\right)$ fixed effects. Standard errors are clustered by firm. ${ }^{17}$

The results are presented in Table 3. Panels A and B show evidence for Scope 1 and Scope 2 emissions, respectively. In Columns (1) and (2), we regress logged global emissions in tons on SEER and the control variables. In Panel A, the coefficient on SEER is negative, indicating that firms exposed to strict environmental policies in their home country pollute less globally. A onestandard-deviation increase in SEER (0.90) is associated with a 14\% decrease in global emissions after controlling for firm size, home-country characteristics, and industry-year fixed effects. ${ }^{18}$ The results for Scope 2 emissions in Panel B are of similar magnitude. These effects are not only statistically significant but also economically relevant: For the average firm that emits 3.15 million tons of global Scope $1 \mathrm{CO}_{2}$ each year, a 14\% reduction amounts to 441,000 fewer tons of $\mathrm{CO}_{2}$ emitted each year.

The results are robust to different regression specifications. In the regressions presented in Column (2) of Panels A and B of Table 3, we also control for a firm's share of assets that are

\footnotetext{
${ }^{16}$ We add one to all emissions variables before logging them.

${ }^{17}$ As an alternative specification, we also include country fixed effects in the equation, which brings weakly significant coefficients for foreign emissions (results are available upon request). Given that the time-series variation in SEER within a country is small, our main results can be interpreted as the impact of cross-country differences in SEER. $18 \% \Delta \mathrm{y}=100 *\left(\mathrm{e}^{\beta^{*} \Delta \mathrm{x}}-1\right)=100 *\left(\mathrm{e}^{-0.17 * 0.9}-1\right)=-14.19 \%$.
} 
located abroad. We include this independent variable, which is mainly driven by factors other than environmental regulation, to control for the higher likelihood of foreign emissions when the firm has more assets located abroad for reasons other than environmental regulation, such as labor costs or closeness to customers. Due to the limited availability of the foreign asset share variable, the number of observations in the regressions slightly drops. Our previously documented results remain unchanged, and we find that a firm's share of foreign assets does not influence its global emission levels in either direction.

Overall, these results do not support the commonly held view that an individual country with strict environmental policies can have little impact on global pollution levels. Instead, we document that firms headquartered in highly regulated countries pollute less globally, potentially due to the environmental standards imposed by the home country.

We next test whether the strictness of home-country regulations is related to the geographic allocation of pollution activities. We explore the emissions in logged tons of $\mathrm{CO}_{2}$ at home versus abroad in Columns (3)-(4) and (5)-(6), respectively, of Table 3. Because some firms have zero emissions in their home countries, we use a Tobit model for this specification. ${ }^{19}$ Here, the effect is larger: A one-standard-deviation increase in SEER is associated with up to a $29 \%$ decrease in emissions at home. ${ }^{20}$ By contrast, a one-standard-deviation increase in the strictness of environmental policies at home is associated with up to a $43 \%$ increase in emissions abroad. ${ }^{21}$ As for Scope 2 emissions, Panel B shows that a one-standard-deviation increase in SEER is correlated with a $54 \%$ decrease in home emissions and a $45 \%$ increase in foreign emissions. ${ }^{22}$ For both Scope 1 and Scope 2 emissions at home, we find that a higher foreign asset share significantly reduces a firm's emissions at home; however, this effect does not cancel out the influence of countrywide environmental legislation and enforcement. Our results can be interpreted in the context of Walker (2011), who shows that stricter environmental regulation in the U.S. in the form of the Clean Air Act led to plant-level downsizings and ultimately lower sector-level employment. Lower

\footnotetext{
${ }^{19}$ Because the fraction of observations that is censored is relatively low in our sample, we re-estimate all Tobit regressions in Tables 3 to 5 and Appendix Tables 3 and 4 as OLS. The results remain similar in the alternative specification, and they can be provided upon request.

${ }^{20}$ From Column (3): $100 *\left(\mathrm{e}^{-0.38 * 0.9}-1\right)=-29.0 \%$.

${ }^{21}$ From Column (5): $100 *\left(\mathrm{e}^{0.40 * 0.9}-1\right)=43.3 \%$.

${ }^{22}$ For Column (3): $100 *\left(\mathrm{e}^{-0.48 * 0.9}-1\right)=-54.0 \%$; for Column (5): $100 *\left(\mathrm{e}^{0.41 * 0.9}-1\right)=44.6 \%$.
} 
production at home rather than investment in green technology might thus be responsible for at least part of the reduced home-country emissions.

In Columns (7) to (8), we reaffirm the previous findings by documenting the relation between environmental regulation and foreign emissions as a percentage share of total global emissions. Specifically, a one-standard-deviation increase in the strictness of domestic environmental policies is associated with a $4.0 \%$ greater share of foreign emissions. ${ }^{23}$ The result for Scope 2, in Panel B, shows a larger corresponding effect of 6.6\%. ${ }^{24}$ As foreign Scope 1 (Scope 2) emissions amount to $38.3 \%$ (42.8\%) of total global emissions for the average firm in our sample, these effects are substantial and economically meaningful.

Overall, the findings in Table 3 show that firms headquartered in countries with stricter environmental policies emit less $\mathrm{CO}_{2}$ globally. However, with stricter environmental regulation, the $\mathrm{CO}_{2}$ emissions at home are significantly lower but foreign emission levels (in absolute and relative terms) are significantly higher. These results imply that while strict environmental policies incentivize firms to allocate polluting activities to countries with weaker environmental policies, we find that country-level environmental regulations are related to lower global pollution levels.

\subsection{Where Do Firms Emit $\mathrm{CO}_{2}$ ?}

We next examine where firms pollute. The analysis in this section explores whether multinational firms pollute in foreign countries that have weaker or stronger environmental policies than those in their home country. To investigate this issue, we construct a firm-countryyear panel and estimate the amount of $\mathrm{CO}_{2}$ emissions by a firm in a specific country each year. In contrast to the previous specification, which focused on the environmental policies in the home country, the disaggregated model allows us to determine how the difference between home and foreign environmental policies is related to the location of emissions. Specifically, we test whether a firm's tendency to transfer polluting activity to a foreign country increases with the difference between domestic environmental policies and those abroad.

${ }^{23} 4.46 \% * 0.9=4.0 \%$.

${ }^{24} 7.35 \% * 0.9=6.6 \%$. 
Figure 4 provides an intuitive visualization of our approach using a firm-target country pair analysis. We focus on the emissions of firm $i$ in foreign country $c$ in year $t$, and only include the observations for which the SEER scores in the home and foreign country are known. In addition, we drop observations of firms with zero emissions in foreign country $c$ in year $t$ to avoid any potential bias in calculating means from zero-emission observations. The variable of interest is the difference between the SEER of firm i's home country and the SEER in foreign country $c$. On the $x$-axis, the left bars represent observations with stronger environmental regulations abroad; the middle bars represent observations with similar environmental regulations at home and abroad; and the right bars represent observations with stronger environmental regulations at home. The $y$ axis shows tons of $\mathrm{CO}_{2}$ emissions per GDP of the foreign country, which is averaged across all firm-country-year observations. The figure shows that pollution abroad increases monotonically with the gap in the stringency of environmental policies. In other words, firms emit in foreign countries where the gap in environmental regulation is most favorable to them.

To implement the analyses with the firm-country-year panel in a regression setting, we use the following procedure. We create a firm-country-year combination matrix that has a cell for each firm $i$ corresponding to each of the 149 foreign target countries $c$ in year $t$ as long as firm $i$ reports non-zero global $\mathrm{CO}_{2}$ emissions in a given year $t .{ }^{25}$ In each cell, we record the pollution of the firm in the country during the specific year. Importantly, we also have a cell with a value of zero for firm-country-years in which no activity was recorded. In fact, about $95 \%$ of our dataset has zero activity. We drop all cells related to the firm's activity in its home country because our intention is to study the choice of foreign countries to target for pollution.

Using the firm-country-year panel data, we estimate the following equation:

$$
y_{i c t}=\beta_{1}\left(S E E R_{\text {home }}-S E E R_{\text {foreign }}\right)+\beta_{2} \text { Controls }+\sigma_{s t}+\pi_{c}+\theta_{h}+\varepsilon_{i c t} \text {, }
$$

where the dependent variable includes the level and proportion of foreign emissions by firm $i$ in country $c$ in year $t$. Our variable of interest is the difference between SEER $R_{\text {home }}$ and SEER foreign, the environmental policy scores for the home country $(h)$ and the foreign country $(c)$ in year $t$. The

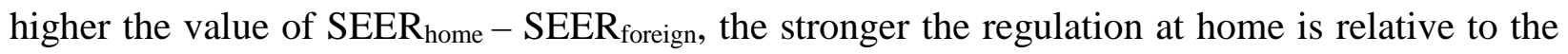
foreign country.

\footnotetext{
${ }^{25}$ Our analysis is limited to the 150 countries for which environmental policy scores (SEER) are available.
} 
Table 4 shows the results of the regressions using the firm-target country-year panel. In each model, we regress either the logged $\mathrm{CO}_{2}$ emissions (in tons) or the percentage of global emissions the firm emits in the foreign country on the difference in SEER scores between the home and the foreign country. As before, we control for logged firm assets and the share of foreign assets. In addition, we control for the foreign country's GDP and country-pair variables that reflect the following relations between the home and the foreign country: logged geographic distance (in kilometers), whether the countries share a common border, whether the countries share a colonial history, and the logged trade volume between the two countries (in US\$ bn). We also include industry-year $\left(\sigma_{s t}\right)$, foreign-country $\left(\pi_{c}\right)$, and home-country $\left(\theta_{h}\right)$ fixed effects.

In all regressions in Table 4, the coefficients for SEER home - SEER $_{\text {foreign }}$ are positive and significant. These results indicate that foreign emissions are higher in countries where environmental regulation is weaker than in the firm's home country. The effects are sizable: A one-standard-deviation (1.52) increase in the relative strictness of the environmental policies at home compared to abroad is associated with up to an $84 \%$ increase in emissions in the respective foreign country. ${ }^{26}$ This finding suggests that firms export pollution to countries where environmental regulation is relatively weaker. As the home and foreign country fixed effects capture the time-invariant unobservable factors of each country, the significance of the difference in SEER implies that allocation of polluting activities is a function of the differentials in the stringency of environmental policies between two countries. In other word, the results from the granular panel data at the firm-country-year level provide direct evidence of carbon leakage by multinational firms.

The other control variables have the expected signs: Emissions are higher for larger, more international firms and when countries are geographically closer, trade more with each other, or share a colonial history. The higher percentage of production occurs in foreign countries, the higher its foreign emissions. These results make intuitive sense considering that emissions are the direct result of a firm's production or operations.

\footnotetext{
${ }^{26}$ From Column (1): $100 *\left(\mathrm{e}^{0.40 * 1.52}-1\right)=83.7 \%$
} 


\section{Economic Mechanisms}

Our baseline results in Section 3 show that firms headquartered in countries with strict environmental policies reduce overall $\mathrm{CO}_{2}$ emissions, but they shift polluting activities to foreign countries, specifically those with relatively more lenient regulations relative to their home countries. In this section, we investigate the economic drivers of this finding. First, we examine whether a push (stricter policies in home countries) or a pull (more lenient policies in foreign countries) is the main driver behind multinational firms’ pollution behavior. Second, we explore whether tightening or relaxing environmental policies has symmetric effects. Lastly, we consider the possibility that firms facing strict regulations pass polluting activities along supply chains.

\subsection{Pushed Away by Strict Domestic Policies or Attracted by Lenient Foreign Policies?}

Our main finding that multinationals tend to export pollution when environmental policies are strict in the home country can be explained by two non-mutually exclusive mechanisms. First, strict domestic policies can push away firms to pollute abroad. Facing tightened domestic policies, firms have a stronger incentive to export their polluting operations, because reducing emissions might be costly and can require investment in resources (the "push" force). Second, countries with more lenient environmental policies may “attract” pollution from firms headquartered in countries with relatively stricter environmental policies. In this case, even without any changes in domestic regulations, firms can be attracted by looser foreign policies and shift their polluting operations abroad (the "pull” force).

Our firm-target country-year panel dataset allows us to tease out these two forces. To assess whether multinational firms are pushed away from tighter policies in their home countries or are attracted by more lenient policies in foreign countries, we implement the following specifications:

$$
\begin{gathered}
y_{i c t}=\gamma_{1} S E E R_{\text {home }}+\gamma_{2} \text { Controls }+\sigma_{s t}+\pi_{c t}+\theta_{h}+\varepsilon_{i c t} \\
y_{i c t}=\delta_{1} S E E R_{\text {foreign }}+\delta_{2} \text { Controls }+\sigma_{s t}+\pi_{c}+\theta_{h t}+\varepsilon_{i c t}
\end{gathered}
$$

where the dependent variable is the level or the proportion of foreign emissions. In equation (A), we include foreign country-year fixed effects $\left(\pi_{c t}\right)$ to control for time-varying foreign country conditions. Thus, in this specification, we compare firms located in different home countries and 
examine whether they are polluting more within the same foreign country, depending on the strictness of environmental policies in their home country. If the stricter domestic policy drives firms to export pollution (the push hypothesis), holding fixed the foreign-country conditions, we expect that $\gamma_{1}>0$. In equation (B), we examine the opposite force by including home countryyear fixed effects $\left(\theta_{h t}\right)$. We examine the effect of the strictness of foreign environmental policy on attracting firms, comparing the behavior of all multinational firms within the same home country-year. If the looser foreign regulations are the main driver of firms' foreign emissions (the pull hypothesis), we expect that $\delta_{1}<0$.

Table 5 reports the results. We find that in Panel A, the coefficients on SEER home are positive and significant, but in Panel B, those on $S E E R_{\text {foreign }}$ are not statistically different from zero. The economic interpretation is that domestic countries that strengthen environmental policies push out multinational firms to emit $\mathrm{CO}_{2}$ abroad. However, we find no evidence that countries that loosen environmental policies attract multinational firms to pollute in their countries. These findings highlight the importance of global regulatory coordination, given that many countries have been tightening domestic environmental policies. While our results in Table 4 generally support the pollution haven hypothesis, the findings in Table 5 suggest that firms are pushed abroad, as opposed to being pulled there.

\subsection{Asymmetric Effects of Changes in Environmental Policies}

We next explore whether the tightening or weakening of environmental policies has a symmetric impact. We design the following test to estimate the sensitivities of $\mathrm{CO}_{2}$ emissions to changes in domestic environmental policies, separately for the years when regulations were tightened and for those when they were loosened:

$$
y_{i t}=\rho_{1} \text { Tightening SEER } R_{t}+\rho_{2} \text { Weakening SEE } R_{t}+\gamma_{2} \text { Controls }+\sigma_{s}+\theta_{h}+\varepsilon_{i t} .
$$

We estimate this equation using a firm-year panel. Tightening $S E E R_{t}$ is defined as $\operatorname{Max}\left(0, \Delta S E E R_{t}\right)$ and Weakening $S E E R_{t}$ as $\operatorname{Min}\left(\triangle S E E R_{t}, 0\right)$, where $\triangle S E E R_{t}$ is the change in the environmental regulation index of the firm's home country in year $t\left(S E E R_{t}\right)$, relative to the index of the country in the first year of the sample period $\left(S E E R_{0}\right)$. The estimation includes industry $\left(\sigma_{s}\right)$ and country $\left(\theta_{h}\right)$ fixed effects to capture the impact of yearly changes in 
environmental policies within a country. If the strictness of environmental regulation has a symmetric effect regardless of the direction of the changes (i.e., either $\triangle S E E R_{t}>0$ (tightening) or $\triangle S E E R_{t}<0$ (weakening)), we expect that $\rho_{1}=\rho_{2}$. In contrast, if $\rho_{1} \neq \rho_{2}$, the effect is asymmetrical.

Table 6 reports the results. We find that the effect of SEER on firms' foreign emissions is indeed asymmetric. In Columns (3) and (7), the coefficients on Tightening SEER are statically significant, but the coefficients on Weakening SEER are either statistically insignificant or take the opposite sign. These results suggest that tightening environmental policies at home drives firms to shift polluting activities to foreign countries, but that relaxing environmental policies does not have the opposite impact of increasing home emissions and decreasing foreign emissions. The economic magnitude of SEER on foreign emissions is sizable given that most countries tightened environmental policies (68\% country-year observations), rather than loosening them, during our sample period.

\subsection{Outsourcing Pollution: Substitution along the Supply Chain}

Although our results on overall emissions are consistent with firms strategically moving polluting activities abroad and reducing home emissions, we cannot perfectly rule out other possibilities. Scope 1 and Scope 2 emissions only capture the direct $\mathrm{CO}_{2}$ emissions from firms' manufacturing and production activities and its purchased electricity. Thus, our interpretation of the impact of regulation on overall pollution levels should come with a caveat because it is possible that firms under tight regulations might externalize polluting activities along supply chains.

We consider the substitution effect along supply chains in response to strict domestic environmental policies. We collect Scope 3 emission information, which is only reported at the firm level, for a subset of firms during the period of 2009-2013. ${ }^{27}$ Despite the limited availability,

\footnotetext{
${ }^{27}$ As of 2012, CDP asks firms to disclose the following standard sources for Scope 3 emissions: business travel, purchased goods and services, waste generated in operations, capital goods, downstream transportation and distribution, employee commuting, fuel- and energy-related activities (not included in Scope 1 or 2), downstream leased assets, end-of-life treatment of sold products, franchises, investments, other (downstream), other (upstream), processing of sold products, upstream leased assets, upstream transportation and distribution, use of sold products, purchased goods \& services, upstream transportation \& distribution, and fuel- and energy-related activities (not included in Scopes 1 or 2). Before 2012, firms were free to define their own Scope 3 categories. While our main dataset covers the global, home, and foreign Scope 1 and 2 emissions of 1,970 firms from 48 countries, only 816 firms from 30 countries report global Scope 3 emissions.
} 
the Scope 3 emissions data allow us to estimate broader impacts of environmental policies on other related firms along the supply chains. We estimate the equation introduced in Section 4.2 using data on global Scope 3 emissions. The results are reported in Column (9) of Table 6.

We find that overall Scope 3 emissions increase when environmental policies tighten. However, we do not find the equivalent symmetric effect when firms face loosening regulations. The substituting effect of delegating polluting activities through supply chains is sizable: A onestandard-deviation increase in $\triangle S E E R(0.22)$ is associated with a 22.7\% increase in Scope 3 global emissions. ${ }^{28}$ This result implies that as environmental policies tighten, multinational firms are more disposed to substitute pollution in their own local activities (Scope 1) with pollution of upstream or downstream firms (Scope 3).

\section{$5 \quad$ Additional Results}

In this section, we explore the heterogeneity in multinational firms' behavior in regard to exporting pollution. We consider two cross-sectional differences: firm governance structure and industry characteristics. We further corroborate our findings by conducting robustness tests on the environmental policy measures and control variables and by addressing the concern of selfreporting bias.

\subsection{Role of Corporate Governance}

Corporate governance could potentially affect how firms respond to a country's environmental policies. Managers of well-governed firms look after the interests of their investors. Traditionally, such interests have been confined to their financial interests; therefore, firms with good corporate governance are expected to minimize costs. ${ }^{29}$ As such, if governance is related to the maximization of profits and complying with strict home environmental regulation is costly, we would expect firms with good corporate governance to be more likely to shift emissions to foreign countries when home environmental policies are strict.

\footnotetext{
${ }^{28}$ From Column (9): $100 *\left(\mathrm{e}^{0.93 * 0.22}-1\right)=22.7 \%$

${ }^{29}$ In recent years, a growing number of institutional investors are also interested in returns that go over and above financial returns, that is, firms should not only look after their financial stakeholders but also other material stakeholder groups that are crucial for the long-term business success of the company.
} 
To explore the role of corporate governance in moderating the correlation between the degree of $\mathrm{CO}_{2}$ emissions and environmental policies, we interact SEER with I(Strong governance), a dummy variable indicating good corporate governance practices. I(Strong governance), based on the CGVSCORE from the Asset4 dataset, receives a value of one for a score that is above the annual in-sample median. The CGVSCORE takes into account more than 250 individual governance aspects of the firm in the areas of board structure, compensation policy, board functions, shareholder rights, and strategy. As reported in Panel A of Table 2, the average corporate governance score in our sample is $65.1 \%$ and the median is $76.5 \%$.

The corporate governance analysis is presented in Table 7. The regression results show that firms with above-median corporate governance scores are more sensitive to home environmental policies; that is, they emit less in their home country when environmental policies are strict (Column (2)). The results in both Panel A and B indicate that whereas poorly governed firms have higher foreign emissions when home environmental policies are strict, well-governed firms do not emit more Scope 1 and Scope 2 emissions abroad (the interaction cancels out the main effect; see the F-test in Column (3)). Well-governed firms thus reduce emissions at home while keeping foreign emissions unchanged. This leads to an overall higher percentage share of foreign emissions (the interaction adds to the main effect; F-test for Column (4)), but this effect is mechanical, meaning that it is driven by reduced home emissions but not by increased foreign emissions.

There could be multiple non-mutually exclusive explanations for these effects. First, managers in well-governed firms may have a genuine interest in sacrificing short-term gains for long-term benefits to the firm and its stakeholders (see Shapira and Zingales, 2017, for a case study of pollution by DuPont). Second, well-governed firms may attract investors who care about corporate social responsibility and advocate for such investments. In other words, good corporate governance could be a proxy for a strong shareholder base that pushes an agenda of corporate social responsibility.

Our finding is consistent with recent papers documenting that firms' compliance with environmental standards is positively recognized by shareholders. For example, Dowell, Hart, and Yeung (2000) find that firms that comply with strict environmental regulations by global standards have higher Tobin's Q ratios than those that only adopt local standards. Chava (2014) documents that firms that emit substantial amounts of hazardous and toxic chemicals pay a higher cost of 
equity and debt capital than those without such environmental concerns. ${ }^{30}$ Our result of the prudent polluting behaviors of well-governed firms suggests that strong firm-level governance can mitigate negative externalities associated with strict national regulations.

\subsection{Pollution-intensive Industries}

We next examine whether firms adjust their behavior with respect to home-country environmental policy differently across industries. We are interested in the pollution-intensive industries that account for most emissions. The underlying hypothesis in this section is that firms in pollution-intensive industries are more likely to shift their emissions abroad rather than try to minimize them in the home country.

We define I(Pollution intensive) as a dummy for firms in industries with high pollution intensity. We base our indicator on the definition used by the European Union (EU), which measures the kilograms of $\mathrm{CO}_{2}$ emitted in generating one euro of gross value added. The industryyear table provided by the EU is presented in Panel A of Appendix Table 2, and Figure 5 shows the industry averages in graphical form. The chart clearly shows three groups of polluting industries. The top two industries - electricity, gas, steam and air conditioning supply, and manufacturers of coke and refined petroleum products-emit around 6 kilograms of $\mathrm{CO}_{2}$ per one euro of gross value added. The next four industries - air transport, water transport, manufacture of other nonmetallic mineral products, and manufacture of basic metals-emit between 3 and 4 kilograms of $\mathrm{CO}_{2}$ per one euro of gross value added. All other industries emit less than 2 kilograms of $\mathrm{CO}_{2}$ per one euro of gross value added. Based on these figures, we define pollution-intensive firms as those in the top six polluting industries.

Panel B of Appendix Table 2 presents summary statistics for firms classified as in pollution-intensive industries and the rest of firms. ${ }^{31}$ Only $6.5 \%$ of all firm-years for which we have matched industry information are classified as pollution-intensive, yet the total emissions of

\footnotetext{
${ }^{30}$ Given this evidence that environmental policies can affect firm value, several recent studies have attempted to identify determinants of firms’ polluting behaviors. For example, financial constraints are known to exacerbate firms' incentives to pollute (Bartram, Hou, and Kim, 2019; Levine, Lin, Wang, and Xie, 2018; Kim and Xu, 2020; Shive and Forster, 2020). Our paper adds to this strand of the literature by providing evidence on the importance of operating locations in understanding firms' polluting incentives.

${ }^{31}$ We lost some firm-year observations in a subset of the sample that we could not map into the NACE industry codes.
} 
Scope $1 \mathrm{CO}_{2}$ emissions by this small fraction of firms is as large as the total emissions by the rest of the sample (93.5\%). ${ }^{32}$

With this definition of pollution-intensive industries, we test whether their sensitivity to environmental policy strictness is different from that of firms in other industries. The industry analysis is presented in Table 8. Panel A focuses on Scope 1 emissions. The regressions in Columns (1) and (2) show that firms in pollution-intensive industries are not sensitive to environmental policies in regard to their global emissions or home emissions (F-test is not statistically significant). In contrast, Column (3) shows that in regard to emissions in foreign countries, these firms are twice as sensitive to home environmental policies. Hence, when domestic environmental policies are strict, firms in pollution-intensive industries emit significantly more in foreign countries. Panel B presents the corresponding results for Scope 2 emissions. While the results are similar, they are not identical. Columns (1) and (2) show that firms in pollutionintensive industries are sensitive to home environmental policies to a lesser degree than firms in non-pollution-intensive industries. Columns (3) and (4) show analogous results to those in the corresponding columns of Panel A: Firms in pollution-intensive industries have nearly twice the sensitivity to home environmental policies when it comes to polluting in foreign countries.

These results have important implications for policymakers because firms in pollutionintensive industries emit materially greater amounts of $\mathrm{CO}_{2}$. Thus, environmental policies that target these industries may be more effective in reducing total emissions. At the same time, our results show that firms in these industries are polluting significantly more in foreign countries when their home country has more stringent policies. This effect potentially indicates that the cost of reducing emissions in these industries is high, causing firms to transfer polluting activities abroad.

\subsection{The Influence of Stringency and Enforcement of Environmental Regulation}

Our measure of a country's environmental regulation rests on both stringency and enforcement. Thus, we also investigate each of these factors separately to determine whether our findings are driven by either the stringency or the enforcement of environmental regulation at

\footnotetext{
${ }^{32}$ Firms in pollution-intensive industries are responsible for $52 \%$ of global Scope $1 \mathrm{CO}_{2}$ pollution. We reach this conclusion by summing the tonnage of $\mathrm{CO}_{2}$ emissions across all firm-years in both parts of the sample.
} 
home, or by both. In Appendix Table 3, we address this issue and separate SEER into its two components: SER (stringency of environmental regulation) and EER (enforcement of environmental regulation). In Panels A and B, we investigate the individual effects of SER and EER on firms' Scope 1 and Scope 2 emissions levels, respectively. Our results show that individually, both the stringency of environmental regulation and the enforcement of this regulation significantly affect emissions levels in the same ways. The results are in line with our main findings reported in Table 3: Firms in countries with more stringent and more strongly enforced environmental regulations emit less in total, less at home, but more abroad. The individual effects of SER and EER are economically meaningful: A one-standard-deviation increase in SER (0.56) is associated with up to a 30\% decrease in emissions at home and up to a $37 \%$ increase in emissions abroad. ${ }^{33}$ Similarly, a one-standard-deviation increase in EER (0.68) is associated with up to a $34 \%$ decrease in emissions at home and up to a $40 \%$ increase in emissions abroad. $^{34}$

In Panels C and D of Appendix Table 3, we go one step further and investigate the simultaneous effects of SER and EER on emissions levels. To do so, we orthogonalize EER in our regression specifications. The results show that although the stringency of environmental regulations, SER, negatively affects overall and home emissions levels, it positively affects the absolute and relative foreign emissions levels. These results are consistent with our previously documented findings. Similarly, the enforcement of environmental regulation, EER, significantly affects home and foreign emissions levels above and beyond SER, with the exception of foreign Scope 2 emissions, which just miss the 10\% significance level (Column (3) in Panel D). This finding implies that the enforcement and stringency of environmental regulations are complementary in shaping a firm’s pollution behavior.

\footnotetext{
${ }^{33}$ From Column (3) in Panel A: $100 *\left(\mathrm{e}^{-0.48 * 0.56}-1\right)=-23.6 \%$; from Column (3) in Panel B: $100 *\left(\mathrm{e}^{-0.66 * 0.56}-1\right)=$ $-30.9 \%$; from Column (5) in Panel A: $100 *\left(\mathrm{e}^{0.47 * 0.56}-1\right)=30.1 \%$; from Column (5) in Panel B: $100 *\left(\mathrm{e}^{0.57 * 0.56}-\right.$ 1) $=37.6 \%$.

${ }^{34}$ From Column (4) in Panel A: $100 *\left(\mathrm{e}^{-0.47 * 0.68}-1\right)=-27.4 \%$; from Column (4) in Panel B: $100 *\left(\mathrm{e}^{-0.64 * 0.68}-1\right)=$ -34.4\%; from Column (6) in Panel A: $100 *\left(\mathrm{e}^{0.44 * 0.68}-1\right)=35.3 \%$; from Column (6) in Panel B: $100 *\left(\mathrm{e}^{0.50 * 0.68}-\right.$ 1) $=40.5 \%$.
} 


\subsection{Addressing Potential Self-Reporting Bias}

The underlying information from CDP on emissions is self-reported by firms. This fact raises concerns that our data could have a self-reporting bias. To address this possibility, we conduct a subsample analysis similar to our main analysis in Table 3 . This time, however, we only include in our sample firms whose $\mathrm{CO}_{2}$ emissions are externally verified by the firms' auditors. This analysis enables us to rule out the potential effects of a self-reporting bias on our findings. The drawback of this subsample is that it reduces the sample size by about $40 \%$.

The findings of this subsample analysis are presented in Appendix Table 4. The results are generally consistent with our main results in Table 3: SEER has a negative effect on global and home emissions levels and a positive relation with foreign emissions (both absolute and relative). This observation implies that among firms whose reported emissions are externally verified, stricter environmental regulations in the home market lead to lower emissions at home but to higher emissions abroad. The economic effects are similar to those reported in Table 3. For firms with externally verified emissions, a one-standard-deviation (0.90) increase in the strictness of environmental policies is associated with up to a $31 \%$ smaller share of home emissions ${ }^{35}$ and up to a $32 \%$ greater share of foreign emissions. ${ }^{36}$

\subsection{Controlling for Comparative Advantage}

In Tables 3 and 4, we control for country, industry, and firm characteristics, including the firm's foreign asset share as a broad proxy for the firms' foreign operations. Nevertheless, we might be missing a major consideration in the firm's strategic decision to operate - and thus consequently to pollute - abroad or at home: the comparative advantage a firm has when operating in different countries. If comparative advantage in pollution is correlated with the

\footnotetext{
${ }^{35}$ From Column (2) in Panel A: $100 *\left(\mathrm{e}^{-0.38 * 0.9}-1\right)=-29.0 \%$; from Column (2) in Panel B: $100 *\left(\mathrm{e}^{-0.42 * 0.9}-1\right)=-$ $31.5 \%$.

${ }^{36}$ From Column (3) in Panel A: $100 *\left(\mathrm{e}^{0.26 * 0.9}-1\right)=26.4 \%$; from Column $(3)$ in Panel B: $100 *\left(\mathrm{e}^{0.31 * 0.9}-1\right)=$ $32.2 \%$.
} 
classical advantages in factors of production such as skilled labor and capital, then our SEER coefficients might incorrectly reflect this classical comparative advantage.

To isolate the sheer comparative advantage in $\mathrm{CO}_{2}$ emissions, we additionally control for the classical comparative advantage variables following Romalis (2004) and Nunn (2007). ${ }^{37}$ Doing so reduces the sample size substantially because skilled labor and capital endowment data are not available for all countries in our sample and factor intensities are only available for manufacturing industries.

Results are reported in Appendix Tables 5 and 6 for our firm-year level and firm-countryyear level emissions, respectively. In general, our results are robust to the inclusion of comparative advantage control variables. However, in Appendix Table 5 not all coefficients of SEER ${ }_{\text {home }}$ are significant. To determine whether this reduced significance is due to the inclusion of the comparative advantage controls or the reduced sample size, we re-estimate Appendix Table 5 for the same, smaller samples but without including the comparative advantage controls. We again find some insignificant coefficients for $\mathrm{SEER}_{\text {home, }}$ indicating that the reduced sample size is responsible for the loss in significance and not the addition of the comparative advantage variables. $^{38}$

\section{Conclusion}

Pollution and the emission of greenhouse gases is an undesired externality of manufacturing activity that contributes significantly to the changing climate around the world. This externality is costly to avoid. As a result, firms are likely to find ways to circumvent costly $\mathrm{CO}_{2}$ pollution abatement requirements. One strategy for firms operating in multiple locations could be to transfer manufacturing activities that produce $\mathrm{CO}_{2}$ to countries where environmental regulations are less stringently defined and enforced than in the firm's home market, a concept known as carbon leakage.

Our study sheds light on this argument using a novel dataset comprising firm-level $\mathrm{CO}_{2}$ emissions data. We find a strong pattern that firms indeed locate their $\mathrm{CO}_{2}$ emitting activities in

\footnotetext{
${ }^{37}$ We thank the reviewer for pointing this out to us.

38 The results are available upon request.
} 
countries where environmental regulation is less developed and less stringently enforced: Scope 1 and Scope $2 \mathrm{CO}_{2}$ emissions levels are significantly higher abroad when environmental regulation in the home market is more stringent than abroad. These results hold in a standard firm-level framework as well as in a disaggregated firm-country-level context. More specifically, we find that firms emit less at home when headquartered in countries with stricter regulations. These firms, however, pollute more abroad, typically in countries with weaker regulations.

The combination of push and pull factors can explain our main finding that firms perform their production activities in countries with looser environmental regulation relative to their home country. Our results suggest that tightening environmental policies in home countries, not the laxer policies in foreign countries, incentivize multinational firms to shift polluting activities abroad. In addition, we document that tightening domestic environmental regulations has a strong impact on firm behavior related to pollution transfer, while relaxing them does not have the opposite impact to the same degree. This result underscores the possibility that, without global coordination, strengthening domestic environmental policies could create an unintended negative externality, pushing firms to pollute elsewhere.

On the positive side, the higher foreign emissions levels do not completely outweigh the reduction at home. Thus, individual countries can make a difference. However, our findings overall highlight the need for collective action to bring down global emission levels further. The 2015 Paris Agreement on climate change was an important step toward achieving this goal. If no coordinated effort is undertaken to address climate change, major stakeholders, such as large firms, will find ways to at least partially circumvent strict environmental regulations in certain parts of the world and move their production activities elsewhere. Our results further suggest that policymakers might be most effective if they focus on curbing the ability of pollution-intensive industries to export pollution to countries with laxer environmental regulations.

For multinational firms with production facilities around the globe, our results imply thatdepending on how quickly and effectively countries implement the Paris Agreement and the European Green Deal-they may continue to benefit from the regulatory arbitrage opportunities we document or they should be prepared to invest in pollution-abatement methods and techniques. Whether these international agreements will harmonize national environmental regulation enough 
that firms will no longer have an option to locate operations purely based on concerns about the strictness of environmental regulation in a particular country remains to be seen. 


\section{References}

Bartram, Söhnke M., Kewei Hou, and Sehoon Kim. 2019. Real Effects of Climate Policy: Financial Constraints and Spillovers. Working Paper. The Ohio State University.

Becker, Randy A., and Vernon Henderson. 2000. Effects of Air Quality Regulations on Polluting Industries. Journal of Political Economy 108(2), 379-421.

Becker, Randy A., and Vernon Henderson. 2001. Costs of Air Quality Regulation. In: Carraro, C. and G. E. Metcalf (eds.). 2001. Behavioral and Distributional Effects of Environmental Policy. University of Chicago Press, 159-186.

Ben Kheder, Sonia, and Natalia Zugravu. 2012. Environmental Regulation and French Firms Location Abroad: An Economic Geography Model in an International Comparative Study. Ecological Economics 77, 48-61.

Bento, Antonio, Matthew Freedman, and Corey Lang. 2015. Who Benefits from Environmental Regulation? Evidence from the Clean Air Act Amendments. Review of Economics and Statistics 97(3), 610-622.

Bonnefon, Jean-François, Augustin Landier, Parinitha Sastry, and David Thesmar. 2019. Do Investors Care About Corporate Externalities?. Working Paper. MIT Sloan.

Botta, Enrico, and Tomasz Koźluk. 2014. Measuring Environmental Policy Stringency in OECD Countries: A Composite Index Approach. OECD Economics Department Working Papers, No. 1177, OECD Publishing, Paris.

CDP. 2020. CDP: Driving Sustainable Economies. Retrieved from http://www.cdp.net. Accessed 14 August 2020.

Chava, Sudheer. 2014. Environmental Externalities and Cost of Capital. Management Science 60(9), 2223-2247.

Christainsen, Gregory B., and Robert H. Haveman. 1981. The Contribution of Environmental Regulations to the Slowdown in Productivity Growth. Journal of Environmental Economics and Management 8(4), 381-390.

Cole, Matthew A. 2004. Trade, the Pollution Haven Hypothesis and the Environmental Kuznets Curve: Examining the Linkages. Ecological Economics 48(1), 71-81.

Dam, Lammertjan, and Bert Scholtens. 2012. The Curse of the Haven: The Impact of Multinational Enterprise on Environmental Regulation. Ecological Economics 78, 148-156. 
Depoers, Florence, Thomas Jeanjean, and Tiphaine Jérôme. 2016. Voluntary Disclosure of Greenhouse Gas Emissions: Contrasting the Carbon Disclosure Project and Corporate Reports. Journal of Business Ethics 134(3), 445-461.

Dowell, Glen, Stuart Hart, and Bernard Yeung. 2000. Do Corporate Global Environmental Standards Create or Destroy Market Value? Management Science 46(8), 1059-1074.

Ederington, Josh, Arik Levinson, and Jenny Minier. 2005. Footloose and Pollution-Free. Review of Economics and Statistics 87(1), 92-99.

Eskeland, Gunnar S., and Ann E. Harrison. 2003. Moving to Greener Pastures? Multinationals and the Pollution Haven Hypothesis. Journal of Development Economics 70(1), 1-23.

Glick, Reuven, and Andrew K. Rose. 2016. Currency Unions and Trade: A Post-EMU Reassessment. European Economic Review 87, 78-91.

He, Jie. 2006. Pollution Haven Hypothesis and Environmental Impacts of Foreign Direct Investment: The Case of Industrial Emission of Sulfur Dioxide $\left(\mathrm{SO}_{2}\right)$ in Chinese Provinces. Ecological Economics 60(1), 228-245.

Khwaja, Asim Ijaz, and Atif Mian, 2008, Tracing the Impact of Bank Liquidity Shocks: Evidence from an Emerging Market. American Economic Review 98(4), 1413-1442.

Kim, Incheol, Hong Wan, Bin Wang, and Tina Yang. 2019. Institutional Investors and Corporate Environmental, Social, and Governance Policies: Evidence from Toxics Release Data. Management Science 65(10), 4901-4926.

Kim, Taehyun, and Qiping Xu. 2020. Financial Constraints and Corporate Environmental Policies. Working Paper.

Krueger, Philipp. 2015. Climate Change and Firm Valuation: Evidence from a Quasi-Natural Experiment. Working Paper. University of Geneva.

Krueger, Philipp, Zacharias Sautner, and Laura T. Starks. 2020. The Importance of Climate Risks for Institutional Investors. Review of Financial Studies 33(3), 1067-1111.

Levine, Ross, Chen Lin, Zigan Wang, and Wensi Xie. 2018. Bank Liquidity, Credit Supply, and the Environment. NBER Working Paper 24375. National Bureau of Economic Research, Cambridge.

Navaretti, Giorgio Barba, and Anthony J. Venables. 2013. Multinationals and Industrial Policy. Oxford Review of Economic Policy 29(2), 361-382.

Nunn, Nathan. 2007. Relationship-Specificity, Incomplete Contracts, and the Pattern of Trade. Quarterly Journal of Economics 122(2), 569-600. 
Romalis, John. 2004. Factor Proportions and the Structure of Commodity Trade. American Economic Review 94(1), 67-97.

Schwab, Klaus, and Xavier Sala-i-Martin. 2016. The Global Competitiveness Report 2014-2015. World Economic Forum, Geneva.

Shapira, Roy, and Luigi Zingales. 2017. Is Pollution Value Maximizing? The Dupont Case, Working Paper. University of Chicago.

Shapiro, Alan C., and Paul Hanouna. 2019. Multinational Financial Management, $11^{\text {th }}$ Edition, Wiley Press.

Shive, Sophie, and Margaret Forster. 2020. Corporate Governance and Pollution Externalities of Public and Private Firms. Review of Financial Studies 33(3), 1296-1330.

Stewart, Richard B. 1993. Environmental Regulation and International Competitiveness. The Yale Law Journal 102(8), 2039-2106.

United Nations Environment. 2019. Global Environment Outlook (GEO-6): Healthy Planet, Healthy People. Nairobi. DOI 10.1017/9781108627146.

Wagner, Ulrich J., and Christopher D. Timmins. 2009. Agglomeration Effects in Foreign Direct Investment and the Pollution Haven Hypothesis. Environmental and Resource Economics 43(2), 231-256.

Walker, W. Reed. 2011. Environmental Regulation and Labor Reallocation: Evidence from the Clean Air Act. American Economic Review 101(3), 442-447. 


\section{Table 1. Summary Statistics}

The table shows descriptive statistics on the Scope 1 and $2 \mathrm{CO}_{2}$ emissions and environmental regulation proxies by year from 2008 to 2015. Statistics are based on the sample of all firms that report at least $85 \%$ of their global emissions on a country level and that are headquartered in countries with environmental regulation data. Overall, 1,813 firms from 48 different home countries report Scope 1 emissions, and 1,863 firms from 47 different home countries report Scope 2 emissions. Our proxy for environmental regulation (SEER) combines the World Economic Forum's assessment of a country's stringency and enforcement of environmental regulation. The proxy ranges from 0.14 to 7 , with higher values indicating stricter environmental regulation.

\section{Panel A: Scope 1 Emissions}

\begin{tabular}{cccccc}
\hline & & \multicolumn{4}{c}{ Average across firms } \\
\cline { 3 - 6 } Year & $\begin{array}{c}\text { Number } \\
\text { of firms }\end{array}$ & $\begin{array}{c}\text { Firm's global } \\
\text { emissions in } \\
\text { metric tons }\end{array}$ & $\begin{array}{c}\text { Firm's emissions } \\
\text { in home country } \\
\text { in \% of firm's total } \\
\text { global emissions }\end{array}$ & $\begin{array}{c}\text { Number of } \\
\text { countries in which } \\
\text { firm has emissions }\end{array}$ & $\begin{array}{c}\text { Environmental } \\
\text { regulation (SEER) } \\
\text { in firm's home } \\
\text { country }\end{array}$ \\
\hline 2008 & 573 & $5,004,705$ & 71.9 & 6.0 & 3.9 \\
2009 & 792 & $3,110,120$ & 73.2 & 6.0 & 4.0 \\
2010 & 734 & $3,119,675$ & 61.4 & 8.1 & 4.1 \\
2011 & 807 & $3,059,106$ & 61.5 & 8.2 & 4.1 \\
2012 & 855 & $3,145,869$ & 58.8 & 8.6 & 4.2 \\
2013 & 883 & $2,990,603$ & 59.1 & 9.1 & 4.1 \\
2014 & 1,030 & $2,724,609$ & 56.8 & 9.0 & 4.2 \\
2015 & 1,054 & $2,623,531$ & 56.5 & 9.0 & 4.1 \\
\hline
\end{tabular}

\section{Panel B: Scope 2 Emissions}

\begin{tabular}{cccccc}
\hline & & \multicolumn{4}{c}{ Average across firms } \\
\cline { 3 - 6 } & $\begin{array}{c}\text { Number } \\
\text { of firms }\end{array}$ & $\begin{array}{c}\text { Firm's global } \\
\text { emissions in } \\
\text { metric tons }\end{array}$ & $\begin{array}{c}\text { Firm's emissions } \\
\text { in home country } \\
\text { in \% of firm's total } \\
\text { global emissions }\end{array}$ & $\begin{array}{c}\text { Number of } \\
\text { countries in which } \\
\text { firm has emissions }\end{array}$ & $\begin{array}{c}\text { Environmental } \\
\text { regulation (SEER) } \\
\text { in firm's home } \\
\text { country }\end{array}$ \\
\hline 2008 & 543 & 925,672 & 69.4 & 6.8 & 4.0 \\
2009 & 812 & 740,259 & 69.9 & 6.9 & 4.0 \\
2010 & 756 & 687,451 & 58.3 & 9.5 & 4.1 \\
2011 & 834 & 654,047 & 57.1 & 9.9 & 4.1 \\
2012 & 901 & 685,918 & 53.7 & 10.2 & 4.2 \\
2013 & 918 & 728,495 & 53.3 & 10.7 & 4.1 \\
2014 & 1,083 & 526,509 & 52.4 & 10.6 & 4.1 \\
2015 & 1,100 & 521,705 & 52.6 & 10.6 & 4.1 \\
\hline
\end{tabular}

Panel C: Stringency and Enforcement of Environmental Regulation (SEER)

\begin{tabular}{ccccccccc}
\hline & & & & & & \multicolumn{3}{c}{ Average across firms (as of 2008) } \\
\cline { 7 - 8 } $\mathrm{N}=150$ & Mean & Std Dev & Min & Median & Max & Top 50 & Mid 50 & Bottom 50 \\
\hline 2008 & 2.300 & 1.270 & 0.054 & 1.940 & 5.588 & 3.802 & 1.955 & 1.135 \\
2009 & 2.348 & 1.323 & 0.124 & 1.902 & 5.761 & 3.921 & 1.939 & 1.175 \\
2010 & 2.327 & 1.321 & 0.223 & 1.845 & 6.041 & 3.860 & 1.877 & 1.234 \\
2011 & 2.344 & 1.320 & 0.270 & 1.940 & 5.936 & 3.860 & 1.915 & 1.258 \\
2012 & 2.358 & 1.296 & 0.296 & 1.971 & 5.853 & 3.833 & 1.957 & 1.276 \\
2013 & 2.416 & 1.255 & 0.520 & 2.030 & 5.589 & 3.827 & 2.026 & 1.386 \\
2014 & 2.465 & 1.243 & 0.372 & 2.150 & 5.651 & 3.854 & 2.036 & 1.496 \\
2015 & 2.439 & 1.225 & 0.104 & 2.131 & 5.560 & 3.790 & 2.014 & 1.506 \\
\hline
\end{tabular}




\section{Table 2. Descriptive Statistics}

The table presents descriptive statistics for Scope 1, 2, and $3 \mathrm{CO}_{2}$ emissions variables, the stringency and enforcement of the environmental regulation (SEER) variable, and the firm-level and country-level variables that are used in the empirical analyses that follow. Summary statistics are based on a firm-year panel in Panel A and a firm-country-year panel in Panel B. The definitions of all variables are provided in Appendix Table 1.

\section{Panel A: Sample of Firm-Level Observations}

\begin{tabular}{|c|c|c|c|c|c|c|}
\hline & $\mathrm{N}$ & Mean & Std Dev & Min & Median & Max \\
\hline \multicolumn{7}{|l|}{ Scope $1 \mathrm{CO}_{2}$ emissions } \\
\hline Global emissions ('000 tons) & 6,325 & $3,149.84$ & $13,693.48$ & 0.00 & 88.81 & $183,400.00$ \\
\hline Home emissions ('000 tons) & 6,325 & $1,846.21$ & $8,813.60$ & 0.00 & 33.89 & $180,000.00$ \\
\hline Foreign emissions ('000 tons) & 6,325 & $1,303.63$ & $8,487.66$ & 0.00 & 13.28 & $175,571.07$ \\
\hline $\begin{array}{l}\text { Foreign emissions } \\
\text { (\% of global emissions) }\end{array}$ & 6,325 & 38.30 & 34.68 & 0.00 & 30.23 & 100.00 \\
\hline \multicolumn{7}{|l|}{ Scope $2 \mathrm{CO}_{2}$ emissions } \\
\hline Global emissions ('000 tons) & 6,530 & 678.94 & $2,683.42$ & 0.00 & 136.04 & $120,000.00$ \\
\hline Home emissions ('000 tons) & 6,530 & 374.62 & 2,069.16 & 0.00 & 49.23 & $120,000.00$ \\
\hline Foreign emissions ('000 tons) & 6,530 & 304.31 & $1,541.90$ & 0.00 & 27.43 & $75,300.00$ \\
\hline $\begin{array}{l}\text { Foreign emissions } \\
\text { (\% of global emissions) }\end{array}$ & 6,530 & 42.83 & 35.78 & 0.00 & 37.52 & 100.00 \\
\hline \multicolumn{7}{|l|}{ Scope $3 \mathrm{CO}_{2}$ emissions } \\
\hline Global emissions ('000 tons) & 2,707 & $14,672.47$ & $111,383.38$ & 0.00 & 63.30 & $4,736,002.50$ \\
\hline \multicolumn{7}{|c|}{ Environmental regulation in firm's home country } \\
\hline SEER $(0.14-7)$ & 7,016 & 4.11 & 0.90 & 1.07 & 4.00 & 6.04 \\
\hline SER (1-7) & 7,016 & 5.43 & 0.56 & 2.90 & 5.38 & 6.63 \\
\hline EER (1-7) & 7,016 & 5.23 & 0.68 & 2.58 & 5.23 & 6.41 \\
\hline Tightening SEER & 6,411 & 0.26 & 0.22 & 0.00 & 0.26 & 1.05 \\
\hline Weakening SEER & 6,411 & -0.07 & 0.17 & -1.08 & 0.00 & 0.00 \\
\hline \multicolumn{7}{|l|}{ Firm characteristics } \\
\hline Assets (\$m) & 7,016 & 60.70 & 194.00 & 0.31 & 8.83 & $1,485.05$ \\
\hline Foreign asset share (\%) & 5,417 & 26.40 & 26.15 & 0.00 & 17.54 & 98.77 \\
\hline CGVSCORE (0-100) & 6,086 & 65.07 & 28.11 & 1.55 & 76.53 & 97.67 \\
\hline \multicolumn{7}{|l|}{ Home country characteristics } \\
\hline GDP (\$bn) & 7,016 & $5,384.21$ & $6,106.45$ & 19.56 & $2,646.00$ & $18,040.00$ \\
\hline GDP per capita growth (\%) & 7,016 & 0.64 & 2.43 & -9.00 & 0.93 & 25.56 \\
\hline CA(Skill) & 3,146 & 0.61 & 0.52 & -0.86 & 0.49 & 2.10 \\
\hline CA(Capital) & 3,146 & 12.37 & 8.18 & 1.96 & 10.15 & 80.23 \\
\hline
\end{tabular}




\section{Table 2. Descriptive Statistics (Cont.)}

\section{Panel B: Sample of Firm-Country-Level Observations}

\begin{tabular}{|c|c|c|c|c|c|c|}
\hline & $\mathrm{N}$ & Mean & Std Dev & Min & Median & Max \\
\hline \multicolumn{7}{|l|}{ Scope $1 \mathrm{CO}_{2}$ emissions } \\
\hline Foreign emissions ('000 tons) & 671,717 & 8.75 & 319.98 & 0.00 & 0.00 & $66,000.00$ \\
\hline $\begin{array}{l}\text { Foreign emissions } \\
\text { (\% of global emissions) }\end{array}$ & 671,717 & 0.27 & 2.90 & 0.00 & 0.00 & 100.00 \\
\hline \multicolumn{7}{|l|}{ Scope $2 \mathrm{CO}_{2}$ emissions } \\
\hline Foreign emissions ('000 tons) & 689,448 & 2.23 & 70.23 & 0.00 & 0.00 & $14,000.00$ \\
\hline $\begin{array}{l}\text { Foreign emissions } \\
\text { (\% of global emissions) }\end{array}$ & 689,448 & 0.31 & 3.15 & 0.00 & 0.00 & 100.00 \\
\hline \multicolumn{7}{|l|}{ Environmental regulation } \\
\hline $\mathrm{SEER}_{\text {home }}-\mathrm{SEER}_{\text {foreign }}$ & 744,782 & 1.80 & 1.52 & -4.26 & 2.04 & 5.67 \\
\hline \multicolumn{7}{|l|}{ Firm characteristics } \\
\hline Assets (\$m) & 744,782 & 51.05 & 146.77 & 0.12 & 8.79 & 960.47 \\
\hline Foreign asset share (\%) & 744,782 & 26.46 & 26.14 & 0.00 & 17.81 & 98.77 \\
\hline \multicolumn{7}{|l|}{ Foreign country characteristics } \\
\hline GDP (\$bn) & 744,782 & 462.94 & $1,519.03$ & 0.69 & 52.91 & $18,039.99$ \\
\hline CA(Skill) & 299,089 & -0.18 & 0.67 & -3.35 & -0.16 & 2.25 \\
\hline CA(Capital) & 330,921 & 10.97 & 7.50 & 1.49 & 8.92 & 84.28 \\
\hline \multicolumn{7}{|l|}{ Home country characteristics } \\
\hline CA(Skill) & 337,094 & 0.66 & 0.53 & -0.57 & 0.50 & 2.10 \\
\hline CA(Capital) & 337,094 & 12.19 & 8.18 & 1.96 & 9.78 & 80.23 \\
\hline \multicolumn{7}{|l|}{ Country pair characteristics } \\
\hline Geographic distance (km) & 744,782 & $8,196.11$ & $4,090.00$ & 141.00 & $8,403.00$ & $19,885.00$ \\
\hline Common border $(0 / 1)$ & 744,782 & 0.01 & 0.12 & 0.00 & 0.00 & 1.00 \\
\hline Common colonial history (0/1) & 744,782 & 0.05 & 0.22 & 0.00 & 0.00 & 1.00 \\
\hline Trade (\$bn) & 744,782 & 11.40 & 47.28 & 0.00 & 0.66 & 660.22 \\
\hline
\end{tabular}




\section{Table 3. Analysis of Firm-Level Emissions: Effect of Domestic Environmental Policies}

The table presents evidence about the relation between global, home, and foreign emissions and home-country environmental policies. Panels A and B show results for Scope 1 and 2 emissions, respectively. The regressions are conducted on a firm-year panel. Columns (1) and (2) are estimated with ordinary least squares in which the dependent variable is $\ln (1+$ Global emissions). Columns (3)-(8) are estimated using a Tobit model. The dependent variable is $\ln (1+$ Home emissions) in Columns (3) and (4), In(1+Foreign emissions) in Columns (5) and (6), and Foreign emissions in \% of global emissions in Columns (7) and (8). SEER is our proxy for stringency and enforcement of environmental regulation in the firm's home country, with higher values indicating stricter regulation. All regressions include industry-year fixed effects. Standard errors are clustered by firm. The definitions of all variables are provided in Appendix Table 1 . For each independent variable, the top row shows the estimated coefficient and the bottom row shows the $t$-statistic. ***, **, and * indicate significance at the $1 \%$, $5 \%$, and $10 \%$ level, respectively.

\section{Panel A: Scope 1 Emissions}

\begin{tabular}{|c|c|c|c|c|c|c|c|c|}
\hline \multirow{2}{*}{$\begin{array}{l}\text { Dependent variable: } \\
\text { Specification: }\end{array}$} & \multicolumn{2}{|c|}{$\ln (1+$ Global emissions $)$} & \multicolumn{2}{|c|}{$\ln (1+$ Home emissions $)$} & \multicolumn{2}{|c|}{$\ln (1+$ Foreign emissions $)$} & \multicolumn{2}{|c|}{$\begin{array}{c}\text { Foreign emissions in \% } \\
\text { of global emissions }\end{array}$} \\
\hline & $\begin{array}{l}\text { OLS } \\
(1)\end{array}$ & $\begin{array}{l}\text { OLS } \\
(2)\end{array}$ & $\begin{array}{c}\text { Tobit } \\
(3) \\
\end{array}$ & $\begin{array}{c}\text { Tobit } \\
(4)\end{array}$ & $\begin{array}{l}\text { Tobit } \\
(5)\end{array}$ & $\begin{array}{c}\text { Tobit } \\
(6) \\
\end{array}$ & $\begin{array}{c}\text { Tobit } \\
(7)\end{array}$ & $\begin{array}{c}\text { Tobit } \\
(8)\end{array}$ \\
\hline SEER & $\begin{array}{c}-0.17 * * * \\
(-3.40)\end{array}$ & $\begin{array}{l}-0.15^{* *} \\
(-2.53)\end{array}$ & $\begin{array}{c}-0.38 * * * \\
(-4.24)\end{array}$ & $\begin{array}{c}-0.31 * * * \\
(-2.90)\end{array}$ & $\begin{array}{c}0.40^{* * *} \\
(3.90)\end{array}$ & $\begin{array}{l}0.28 * * * \\
(2.61)\end{array}$ & $\begin{array}{c}4.46^{* * *} \\
(4.00)\end{array}$ & $\begin{array}{c}3.24 * * * \\
(2.77)\end{array}$ \\
\hline \multicolumn{9}{|l|}{ Firm characteristics } \\
\hline $\ln$ (Assets) & $\begin{array}{l}1.04 * * * \\
(27.10)\end{array}$ & $\begin{array}{l}1.05^{* * *} \\
(26.00)\end{array}$ & $\begin{array}{l}1.00 * * * \\
(15.68)\end{array}$ & $\begin{array}{l}1.08 * * * \\
(15.84)\end{array}$ & $\begin{array}{l}1.41^{* * *} \\
(19.42)\end{array}$ & $\begin{array}{l}1.29 * * * \\
(18.36)\end{array}$ & $\begin{array}{c}3.74 * * * \\
(4.80)\end{array}$ & $\begin{array}{l}1.66^{* *} \\
(2.28)\end{array}$ \\
\hline Foreign asset share (\%) & & $\begin{array}{c}0.00 \\
(0.19)\end{array}$ & & $\begin{array}{c}-0.03 * * * \\
(-7.49)\end{array}$ & & $\begin{array}{c}0.04 * * * \\
(11.49)\end{array}$ & & $\begin{array}{c}0.62 * * * \\
(16.69)\end{array}$ \\
\hline \multicolumn{9}{|l|}{ Home country characteristics } \\
\hline $\ln (\mathrm{GDP})$ & $\begin{array}{c}0.03 \\
(0.71)\end{array}$ & $\begin{array}{c}0.01 \\
(0.22)\end{array}$ & $\begin{array}{c}0.44^{* * *} \\
(6.24)\end{array}$ & $\begin{array}{c}0.33^{* * *} \\
(3.98)\end{array}$ & $\begin{array}{c}-0.42 * * * \\
(-5.77)\end{array}$ & $\begin{array}{l}-0.18^{* *} \\
(-2.53)\end{array}$ & $\begin{array}{l}-8.43 * * * \\
(-10.93)\end{array}$ & $\begin{array}{c}-5.24 * * * \\
(-6.43)\end{array}$ \\
\hline GDP per capita growth & $\begin{array}{c}0.02 \\
(1.05)\end{array}$ & $\begin{array}{c}0.01 \\
(0.60)\end{array}$ & $\begin{array}{c}0.05 \\
(1.39)\end{array}$ & $\begin{array}{c}0.03 \\
(0.67)\end{array}$ & $\begin{array}{c}-0.18^{* * *} \\
(-4.39)\end{array}$ & $\begin{array}{c}-0.14 * * * \\
(-3.26)\end{array}$ & $\begin{array}{c}-1.81^{* * * *} \\
(-4.24)\end{array}$ & $\begin{array}{c}-1.25^{* * *} \\
(-3.07)\end{array}$ \\
\hline \multicolumn{9}{|l|}{ Fixed effects } \\
\hline Industry $\times$ Year & Yes & Yes & Yes & Yes & Yes & Yes & Yes & Yes \\
\hline Adjusted/Pseudo R-squared & 0.697 & 0.684 & 0.114 & 0.121 & 0.106 & 0.122 & 0.0342 & 0.0569 \\
\hline $\begin{array}{l}\text { Observations } \\
\text { of which censored at } 0\end{array}$ & 6,325 & 4,919 & $\begin{array}{c}6,325 \\
274\end{array}$ & $\begin{array}{c}4,919 \\
226\end{array}$ & $\begin{array}{c}6,325 \\
719\end{array}$ & $\begin{array}{c}4,919 \\
481\end{array}$ & $\begin{array}{c}6,325 \\
719\end{array}$ & $\begin{array}{c}4,919 \\
481\end{array}$ \\
\hline of which censored at 100 & & & & & & & 274 & 226 \\
\hline
\end{tabular}


Table 3. Analysis of Firm-Level Emissions (Cont.)

\section{Panel B: Scope 2 Emissions}

\begin{tabular}{|c|c|c|c|c|c|c|c|c|}
\hline \multirow{2}{*}{$\begin{array}{l}\text { Dependent variable: } \\
\text { Specification: }\end{array}$} & \multicolumn{2}{|c|}{$\ln (1+$ Global emissions $)$} & \multicolumn{2}{|c|}{$\ln (1+$ Home emissions $)$} & \multicolumn{2}{|c|}{$\ln (1+$ Foreign emissions $)$} & \multicolumn{2}{|c|}{$\begin{array}{l}\text { Foreign emissions in \% } \\
\text { of global emissions }\end{array}$} \\
\hline & $\begin{array}{c}\text { OLS } \\
(1)\end{array}$ & $\begin{array}{c}\text { OLS } \\
(2)\end{array}$ & $\begin{array}{c}\text { Tobit } \\
\text { (3) }\end{array}$ & $\begin{array}{c}\text { Tobit } \\
(4)\end{array}$ & $\begin{array}{c}\text { Tobit } \\
\text { (5) }\end{array}$ & $\begin{array}{c}\text { Tobit } \\
(6)\end{array}$ & $\begin{array}{c}\text { Tobit } \\
(7)\end{array}$ & $\begin{array}{c}\text { Tobit } \\
(8)\end{array}$ \\
\hline SEER & $\begin{array}{c}-0.20^{* * *} \\
(-5.00)\end{array}$ & $\begin{array}{c}-0.18 * * * \\
(-4.15)\end{array}$ & $\begin{array}{c}-0.48 * * * \\
(-5.78)\end{array}$ & $\begin{array}{c}-0.43^{* * *} \\
(-4.38)\end{array}$ & $\begin{array}{c}0.41 * * * \\
(4.34)\end{array}$ & $\begin{array}{c}0.34 * * * \\
(3.59)\end{array}$ & $\begin{array}{c}7.35 * * * \\
(6.87)\end{array}$ & $\begin{array}{c}6.60 * * * \\
(5.95)\end{array}$ \\
\hline \multicolumn{9}{|l|}{ Firm characteristics } \\
\hline $\ln$ (Assets) & $\begin{array}{l}0.92 * * * \\
(28.70)\end{array}$ & $\begin{array}{l}0.94 * * * \\
(26.92)\end{array}$ & $\begin{array}{l}0.79 * * * \\
(14.09)\end{array}$ & $\begin{array}{l}0.88 * * * \\
(14.42)\end{array}$ & $\begin{array}{l}1.31 * * * \\
(19.95)\end{array}$ & $\begin{array}{l}1.21 * * * \\
(19.58)\end{array}$ & $\begin{array}{c}4.44^{* * * *} \\
(6.06)\end{array}$ & $\begin{array}{c}2.61 * * * \\
(3.85)\end{array}$ \\
\hline Foreign asset share & & $\begin{array}{c}-0.00 \\
(-1.30)\end{array}$ & & $\begin{array}{c}-0.03 * * * \\
(-8.18)\end{array}$ & & $\begin{array}{c}0.03 * * * \\
(10.67)\end{array}$ & & $\begin{array}{l}0.61 * * * \\
(17.61)\end{array}$ \\
\hline \multicolumn{9}{|l|}{ Home country characteristics } \\
\hline $\ln (G D P)$ & $\begin{array}{c}0.08 * * * \\
(2.65)\end{array}$ & $\begin{array}{l}0.06^{*} \\
(1.94)\end{array}$ & $\begin{array}{c}0.52 * * * \\
(7.95)\end{array}$ & $\begin{array}{c}0.41 * * * \\
(5.56)\end{array}$ & $\begin{array}{c}-0.28 * * * \\
(-4.36)\end{array}$ & $\begin{array}{l}-0.11^{*} \\
(-1.66)\end{array}$ & $\begin{array}{l}-8.55 * * * \\
(-11.31)\end{array}$ & $\begin{array}{c}-5.51 * * * \\
(-7.02)\end{array}$ \\
\hline GDP per capita growth & $\begin{array}{c}0.02 \\
(1.30)\end{array}$ & $\begin{array}{c}0.01 \\
(0.74)\end{array}$ & $\begin{array}{c}0.04 \\
(1.22)\end{array}$ & $\begin{array}{c}0.02 \\
(0.56)\end{array}$ & $\begin{array}{c}-0.19 * * * \\
(-4.66)\end{array}$ & $\begin{array}{c}-0.12 * * * \\
(-3.04)\end{array}$ & $\begin{array}{c}-1.78 * * * \\
(-4.21)\end{array}$ & $\begin{array}{c}-1.08 * * * \\
(-2.80)\end{array}$ \\
\hline \multicolumn{9}{|l|}{ Fixed effects } \\
\hline Industry $\times$ Year & Yes & Yes & Yes & Yes & Yes & Yes & Yes & Yes \\
\hline $\begin{array}{l}\text { Adjusted/Pseudo R-squared } \\
\text { Observations } \\
\text { of which censored at } 0 \\
\text { of which censored at } 100\end{array}$ & $\begin{array}{l}0.579 \\
6,530\end{array}$ & $\begin{array}{l}0.583 \\
5,018\end{array}$ & $\begin{array}{c}0.0789 \\
6,530 \\
230\end{array}$ & $\begin{array}{c}0.0904 \\
5,018 \\
196\end{array}$ & $\begin{array}{c}0.0955 \\
6,530 \\
693\end{array}$ & $\begin{array}{c}0.116 \\
5,018 \\
430\end{array}$ & $\begin{array}{c}0.0373 \\
6,530 \\
693 \\
231\end{array}$ & $\begin{array}{c}0.0590 \\
5,018 \\
430 \\
196\end{array}$ \\
\hline
\end{tabular}




\section{Table 4. Analysis of Firm-Country-Level Emissions: Effect of Environmental Policy Gaps}

The table shows the effect of environmental regulation gaps between home and foreign countries on the firms' emissions in a specific country. We estimate Tobit regressions in which the dependent variable is $\ln (1+$ Foreign emissions) in Columns (1) and (3) and Foreign emissions in \% of global emissions in Columns (2) and (4). Columns (1) and (2) show the results for Scope 1 emissions, and Columns (3) and (4) show the results for Scope 2 emissions. $S E E R_{\text {home }}-S E E R_{\text {foreign }}$ is our proxy for stringency and enforcement of environmental regulation in the home minus the foreign country, with higher values indicating stricter regulation at home. All regressions include industry-year, home country, and foreign country fixed effects. Standard errors are clustered by country-pair. The definitions of all variables are provided in Appendix Table 1. For each independent variable, the top row shows the estimated coefficient and the bottom row shows the $t$-statistic. ${ }^{* * *},{ }^{* *}$, and $*$ indicate significance at the $1 \%, 5 \%$, and $10 \%$ level, respectively.

\begin{tabular}{|c|c|c|c|c|}
\hline \multirow[b]{2}{*}{ Dependent variable: } & \multicolumn{2}{|c|}{ Scope 1 emissions } & \multicolumn{2}{|c|}{ Scope 2 emissions } \\
\hline & $\begin{array}{c}\ln (1+\text { Foreign } \\
\text { emissions })\end{array}$ & $\begin{array}{c}\text { Foreign } \\
\text { emissions } \\
\text { in \% of } \\
\text { global } \\
\text { emissions }\end{array}$ & $\begin{array}{c}\ln (1+\text { Foreign } \\
\text { emissions })\end{array}$ & $\begin{array}{c}\text { Foreign } \\
\text { emissions } \\
\text { in \% of } \\
\text { global } \\
\text { emissions }\end{array}$ \\
\hline Specification: & $\begin{array}{c}\text { Tobit } \\
(1)\end{array}$ & $\begin{array}{c}\text { Tobit } \\
(2) \\
\end{array}$ & $\begin{array}{c}\text { Tobit } \\
(3)\end{array}$ & $\begin{array}{c}\text { Tobit } \\
(4)\end{array}$ \\
\hline SEER home $^{-} \mathrm{SEER}_{\text {foreign }}$ & $\begin{array}{c}0.40^{* * *} \\
(2.93)\end{array}$ & $\begin{array}{l}0.55^{* * *} \\
(3.02)\end{array}$ & $\begin{array}{c}0.47 * * * \\
(3.78)\end{array}$ & $\begin{array}{c}0.52^{* * *} \\
(3.22)\end{array}$ \\
\hline Firm characteristics & & & & \\
\hline $\ln$ (Assets) & $\begin{array}{c}2.39 * * * \\
(32.68)\end{array}$ & $\begin{array}{r}2.30^{* * *} \\
(16.93)\end{array}$ & $\begin{array}{l}1.97 * * * \\
(30.92)\end{array}$ & $\begin{array}{l}1.90^{* * *} \\
(14.36)\end{array}$ \\
\hline Foreign asset share & $\begin{array}{c}0.05^{* * *} \\
(16.37)\end{array}$ & $\begin{array}{l}0.07 * * * \\
(11.68)\end{array}$ & $\begin{array}{l}0.03^{* * *} \\
(13.35)\end{array}$ & $\begin{array}{c}0.05^{* * *} \\
(9.39)\end{array}$ \\
\hline Foreign country characterist & & & & \\
\hline $\ln (G D P)$ & $\begin{array}{c}-0.42 \\
(-1.14)\end{array}$ & $\begin{array}{l}-0.58 \\
(-1.21)\end{array}$ & $\begin{array}{c}0.54 \\
(1.63)\end{array}$ & $\begin{array}{c}0.64 \\
(1.40)\end{array}$ \\
\hline Country pair characteristics & & & & \\
\hline ln(Geographic distance) & $\begin{array}{c}-1.69 * * * \\
(-5.55)\end{array}$ & $\begin{array}{c}-2.18^{* * *} \\
(-5.02)\end{array}$ & $\begin{array}{c}-1.33^{* * *} \\
(-5.01)\end{array}$ & $\begin{array}{c}-1.84^{* * *} \\
(-4.43)\end{array}$ \\
\hline Common border & $\begin{array}{c}0.81 \\
(1.15)\end{array}$ & $\begin{array}{l}2.19^{*} \\
(1.86)\end{array}$ & $\begin{array}{c}0.67 \\
(1.07)\end{array}$ & $\begin{array}{c}1.76 \\
(1.45)\end{array}$ \\
\hline Common colonial history & $\begin{array}{c}3.06^{* * *} \\
(6.42)\end{array}$ & $\begin{array}{c}4.46 * * * \\
(6.41)\end{array}$ & $\begin{array}{c}2.99 * * * \\
(7.44)\end{array}$ & $\begin{array}{c}4.50^{* * *} \\
(6.62)\end{array}$ \\
\hline $\ln$ (Trade) & $\begin{array}{l}1.93^{* * *} \\
(10.00)\end{array}$ & $\begin{array}{c}2.52^{* * *} \\
(8.51)\end{array}$ & $\begin{array}{l}1.86^{* * *} \\
(10.71)\end{array}$ & $\begin{array}{c}2.45^{* * *} \\
(8.94)\end{array}$ \\
\hline Fixed effects & & & & \\
\hline Industry $\times$ Year & Yes & Yes & Yes & Yes \\
\hline Foreign country & Yes & Yes & Yes & Yes \\
\hline Home country & Yes & Yes & Yes & Yes \\
\hline Pseudo R-squared & 0.201 & 0.181 & 0.207 & 0.185 \\
\hline Observations & 671,717 & 671,717 & 689,448 & 689,448 \\
\hline of which censored at 0 & 636,406 & 636,406 & 645,856 & 645,856 \\
\hline of which uncensored & 35,311 & 35,296 & 43,592 & 43,573 \\
\hline of which censored at 100 & & 15 & & 19 \\
\hline
\end{tabular}




\section{Table 5. Home versus Foreign Environmental Policies}

The table shows the effect of environmental regulations in home and foreign countries separately on the firms' emissions in a specific country, using a firm-country-year panel. We estimate Tobit regressions in which the dependent variable is $\ln (1+$ Foreign emissions) in Columns (1) and (3) and Foreign emissions in \% of global emissions in Columns (2) and (4). Columns (1)-(2) and (3)-(4) show the results for Scope 1 and 2 emissions, respectively. Controls include In(Assets), Foreign asset share, In(Geographic distance), Common border, Common colonial history, and $\ln$ (Trade). In Panel A, the main independent variable is SEER home, the environmental policy of home country, and the regressions include industry-year, foreign country-year, and home country fixed effects. In Panel B, the main independent variable is $S E E R_{\text {foreign, }}$ the environmental policy of foreign country, and the regressions include industryyear, foreign country, and home country-year fixed effects. Standard errors are clustered by country-pair. Robust $t$ statistics are shown in parentheses. ${ }^{* *}, * *$, and $*$ indicate significance at the $1 \%, 5 \%$, and $10 \%$ level, respectively.

Panel A: Effect of SEERhome

\begin{tabular}{|c|c|c|c|c|}
\hline \multirow{3}{*}{ Dependent variable: } & \multicolumn{2}{|c|}{ Scope 1 emissions } & \multicolumn{2}{|c|}{ Scope 2 emissions } \\
\hline & $\begin{array}{c}\ln (1+\text { Foreign } \\
\text { emissions })\end{array}$ & $\begin{array}{c}\text { Foreign } \\
\text { emissions in \% of } \\
\text { global emissions }\end{array}$ & $\begin{array}{c}\ln (1+\text { Foreign } \\
\text { emissions })\end{array}$ & $\begin{array}{c}\text { Foreign } \\
\text { emissions in \% of } \\
\text { global emissions }\end{array}$ \\
\hline & (1) & $(2)$ & (3) & (4) \\
\hline SEER $_{\text {home }}$ & $\begin{array}{c}1.03^{* * *} \\
(4.61)\end{array}$ & $\begin{array}{c}1.26^{* * *} \\
(4.22)\end{array}$ & $\begin{array}{c}1.48^{* * *} \\
(7.42)\end{array}$ & $\begin{array}{c}1.61^{* * *} \\
(5.54)\end{array}$ \\
\hline $\begin{array}{l}\text { Controls } \\
\text { Fixed effects }\end{array}$ & Yes & Yes & Yes & Yes \\
\hline Industry $\times$ Year & Yes & Yes & Yes & Yes \\
\hline Foreign country $\times$ Year & Yes & Yes & Yes & Yes \\
\hline Home country & Yes & Yes & Yes & Yes \\
\hline Pseudo R-squared & 0.203 & 0.182 & 0.208 & 0.186 \\
\hline Observations & 671,717 & 671,717 & 689,448 & 689,448 \\
\hline of which censored at 0 & 636,406 & 636,406 & 645,856 & 645,856 \\
\hline of which uncensored & 35,311 & 35,296 & 43,592 & 43,573 \\
\hline of which censored at 100 & & 15 & & 19 \\
\hline
\end{tabular}

\section{Panel B: Effect of SEERforeign}

\begin{tabular}{|c|c|c|c|c|}
\hline \multirow{3}{*}{ Dependent variable: } & \multicolumn{2}{|c|}{ Scope 1 emissions } & \multicolumn{2}{|c|}{ Scope 2 emissions } \\
\hline & $\begin{array}{l}\ln (1+\text { Foreign } \\
\text { emissions })\end{array}$ & $\begin{array}{c}\text { Foreign } \\
\text { emissions in \% of } \\
\text { global emissions }\end{array}$ & $\begin{array}{l}\ln (1+\text { Foreign } \\
\text { emissions })\end{array}$ & $\begin{array}{c}\text { Foreign } \\
\text { emissions in \% of } \\
\text { global emissions }\end{array}$ \\
\hline & $(1)$ & $(2)$ & (3) & $(4)$ \\
\hline $\mathrm{SEER}_{\text {foreign }}$ & $\begin{array}{c}-0.04 \\
(-0.30)\end{array}$ & $\begin{array}{c}-0.13 \\
(-0.65)\end{array}$ & $\begin{array}{c}0.16 \\
(1.22)\end{array}$ & $\begin{array}{c}0.18 \\
(1.02)\end{array}$ \\
\hline $\begin{array}{l}\text { Controls } \\
\text { Fixed effects }\end{array}$ & Yes & Yes & Yes & Yes \\
\hline Industry $\times$ Year & Yes & Yes & Yes & Yes \\
\hline Foreign country & Yes & Yes & Yes & Yes \\
\hline Home country $\times$ Year & Yes & Yes & Yes & Yes \\
\hline Pseudo R-squared & 0.203 & 0.182 & 0.209 & 0.187 \\
\hline Observations & 671,717 & 671,717 & 689,448 & 689,448 \\
\hline of which censored at 0 & 636,406 & 636,406 & 645,856 & 645,856 \\
\hline of which uncensored & 35,311 & 35,296 & 43,592 & 43,573 \\
\hline of which censored at 100 & & 15 & & 19 \\
\hline
\end{tabular}




\section{Table 6. Asymmetric Effects of Environmental Policies}

The table shows the effect of the changes in home-country environmental regulations on the firms' foreign emissions using a firm-year panel. Columns (1) to (4) show results for Scope 1 emissions, Columns (5) to (8) for Scope 2 emissions, and Column (9) for Scope 3 emissions. Columns (1), (5), and (9) are estimated with ordinary least squares, and Columns (2)-(4) and (6)-(8) are estimated using a Tobit model. Standard errors are clustered by firm. Tightening SEER is defined as $\operatorname{Max}\left(0, \Delta S E E R_{\mathrm{t}}\right)$ and Weakening $S E E R$ as $\operatorname{Min}\left(\triangle \mathrm{SEER} \mathrm{t}_{\mathrm{t}}, 0\right)$, where $\triangle \mathrm{SEER}_{\mathrm{t}}$ is the change in the environmental regulation index in the firm's home country in year $t\left(S_{E E R}\right)$, relative to the index of each country in the first year covered during the sample period (SEER $)$. All regressions include industry and home country fixed effects. Standard errors are clustered by firm. For each independent variable, the top row shows the estimated coefficient and the bottom row shows the $t$-statistic. $* * *, * *$, and $*$ indicate significance at the $1 \%, 5 \%$, and $10 \%$ level, respectively.

\begin{tabular}{|c|c|c|c|c|c|c|c|c|c|}
\hline \multirow[b]{2}{*}{ Dependent variable: } & \multicolumn{4}{|c|}{ Scope 1 emissions } & \multicolumn{4}{|c|}{ Scope 2 emissions } & \multirow[b]{2}{*}{$\begin{array}{c}\text { Scope } 3 \text { emissions } \\
\text { ln(1+Global } \\
\text { emissions })\end{array}$} \\
\hline & $\begin{array}{c}\ln (1+\text { Global } \\
\text { emissions })\end{array}$ & $\begin{array}{l}\ln (1+\text { Home } \\
\text { emissions })\end{array}$ & $\begin{array}{c}\ln (1+\text { Foreign } \\
\text { emissions })\end{array}$ & $\begin{array}{c}\text { Foreign } \\
\text { emissions in } \\
\% \text { of global } \\
\text { emissions }\end{array}$ & $\begin{array}{c}\ln (1+\text { Global } \\
\text { emissions })\end{array}$ & $\begin{array}{c}\ln (1+\text { Home } \\
\text { emissions })\end{array}$ & $\begin{array}{c}\ln (1+\text { Foreign } \\
\text { emissions })\end{array}$ & $\begin{array}{c}\text { Foreign } \\
\text { emissions in } \\
\% \text { of global } \\
\text { emissions }\end{array}$ & \\
\hline Specification: & $\begin{array}{l}\text { OLS } \\
(1)\end{array}$ & $\begin{array}{l}\text { Tobit } \\
\text { (2) }\end{array}$ & $\begin{array}{c}\text { Tobit } \\
\text { (3) }\end{array}$ & $\begin{array}{c}\text { Tobit } \\
\text { (4) }\end{array}$ & $\begin{array}{l}\text { OLS } \\
(5)\end{array}$ & $\begin{array}{c}\text { Tobit } \\
(6)\end{array}$ & $\begin{array}{c}\text { Tobit } \\
(7)\end{array}$ & $\begin{array}{c}\text { Tobit } \\
\text { (8) }\end{array}$ & $\begin{array}{c}\text { OLS } \\
\text { (9) }\end{array}$ \\
\hline Tightening SEER & $\begin{array}{c}-0.18 \\
(-1.03)\end{array}$ & $\begin{array}{l}-0.47^{*} \\
(-1.81)\end{array}$ & $\begin{array}{c}1.23^{* * *} \\
(2.94)\end{array}$ & $\begin{array}{c}14.85 * * * \\
(4.63)\end{array}$ & $\begin{array}{c}0.14 \\
(1.07)\end{array}$ & $\begin{array}{c}0.00 \\
(0.02)\end{array}$ & $\begin{array}{c}1.60^{* * *} \\
(4.12)\end{array}$ & $\begin{array}{c}13.65^{* * *} \\
(4.62)\end{array}$ & $\begin{array}{l}0.93^{* *} \\
(1.99)\end{array}$ \\
\hline Weakening SEER & $\begin{array}{c}0.25 \\
(0.92)\end{array}$ & $\begin{array}{c}0.56 \\
(1.24)\end{array}$ & $\begin{array}{c}-0.66 \\
(-1.07)\end{array}$ & $\begin{array}{l}-8.80^{*} \\
(-1.74)\end{array}$ & $\begin{array}{c}0.40 \\
(1.56)\end{array}$ & $\begin{array}{l}0.71^{*} \\
(1.77)\end{array}$ & $\begin{array}{c}-0.60 \\
(-1.08)\end{array}$ & $\begin{array}{l}-9.47^{*} \\
(-1.96)\end{array}$ & $\begin{array}{l}-1.33 \\
(-1.40)\end{array}$ \\
\hline Firm characteristics & & & & & & & & & \\
\hline $\ln$ (Assets) & $\begin{array}{l}1.08^{* * *} \\
(26.01)\end{array}$ & $\begin{array}{l}1.08^{* * *} \\
(15.07)\end{array}$ & $\begin{array}{l}1.31^{* * *} \\
(18.25)\end{array}$ & $\begin{array}{c}2.05^{* * *} \\
(2.97)\end{array}$ & $\begin{array}{l}0.93 * * * \\
(26.70)\end{array}$ & $\begin{array}{l}0.90^{* * *} \\
(14.38)\end{array}$ & $\begin{array}{l}1.16^{* * *} \\
(17.55)\end{array}$ & $\begin{array}{c}2.02^{* * *} \\
(3.20)\end{array}$ & $\begin{array}{l}1.30 * * * \\
(17.97)\end{array}$ \\
\hline Foreign asset share & $\begin{array}{c}0.00 \\
(1.20)\end{array}$ & $\begin{array}{c}-0.02 * * * \\
(-5.79)\end{array}$ & $\begin{array}{c}0.03^{* * *} \\
(8.81)\end{array}$ & $\begin{array}{l}0.48 * * * \\
(12.33)\end{array}$ & $\begin{array}{c}0.00 \\
(0.77)\end{array}$ & $\begin{array}{c}-0.02 * * * \\
(-6.03)\end{array}$ & $\begin{array}{c}0.03 * * * \\
(8.23)\end{array}$ & $\begin{array}{l}0.45^{* * *} \\
(13.40)\end{array}$ & $\begin{array}{c}-0.01 * * * \\
(-2.66)\end{array}$ \\
\hline Home country characteristic & & & & & & & & & \\
\hline $\ln (\mathrm{GDP})$ & $\begin{array}{l}-0.59 * * \\
(-2.24)\end{array}$ & $\begin{array}{c}-1.07 * * * \\
(-2.64)\end{array}$ & $\begin{array}{l}1.47 * * \\
(2.32)\end{array}$ & $\begin{array}{c}13.38 * * * \\
(2.85)\end{array}$ & $\begin{array}{c}-0.86 * * * \\
(-4.53)\end{array}$ & $\begin{array}{c}-1.29 * * * \\
(-3.73)\end{array}$ & $\begin{array}{l}1.43^{* *} \\
(2.42)\end{array}$ & $\begin{array}{c}16.13^{* * *} \\
(3.51)\end{array}$ & $\begin{array}{c}-0.34 \\
(-0.38)\end{array}$ \\
\hline GDP per capita growth & $\begin{array}{c}0.00 \\
(0.16)\end{array}$ & $\begin{array}{l}-0.03 \\
(-1.57)\end{array}$ & $\begin{array}{c}0.14 * * * \\
(5.91)\end{array}$ & $\begin{array}{c}1.02^{* * *} \\
(5.10)\end{array}$ & $\begin{array}{l}-0.02 * * \\
(-2.09)\end{array}$ & $\begin{array}{l}-0.04 * \\
(-1.93)\end{array}$ & $\begin{array}{c}0.13^{* * *} \\
(5.51)\end{array}$ & $\begin{array}{c}0.92^{* * *} \\
(4.70)\end{array}$ & $\begin{array}{c}-0.15^{* * *} \\
(-3.54)\end{array}$ \\
\hline Fixed effects & & & & & & & & & \\
\hline Industry & Yes & Yes & Yes & Yes & Yes & Yes & Yes & Yes & Yes \\
\hline Home country & Yes & Yes & Yes & Yes & Yes & Yes & Yes & Yes & Yes \\
\hline Adjusted/Pseudo R-squared & 0.710 & 0.140 & 0.110 & 0.0653 & 0.641 & 0.128 & 0.101 & 0.0773 & 0.458 \\
\hline $\begin{array}{l}\text { Observations } \\
\text { of which censored at } 0\end{array}$ & 4,506 & $\begin{array}{c}4,506 \\
211\end{array}$ & $\begin{array}{c}4,506 \\
369\end{array}$ & $\begin{array}{c}4,506 \\
369\end{array}$ & 4,631 & $\begin{array}{c}4,631 \\
189\end{array}$ & $\begin{array}{c}4,631 \\
326\end{array}$ & $\begin{array}{c}4,631 \\
326\end{array}$ & 2,035 \\
\hline of which censored at 100 & & & & 211 & & & & 189 & \\
\hline
\end{tabular}




\section{Table 7. Environmental Regulation and Firms' Corporate Governance}

The table shows the role of firms' corporate governance modulating the relationship between the domestic environmental policy and firms' emissions. Panels A and B show results for Scope 1 and 2 emissions, respectively. Results are estimated using ordinary least squares (Column (1)) and Tobit (Columns (2)-(4)) regressions with standard errors clustered by firm. Controls include $\ln$ (Assets), Foreign asset share, $\ln (G D P)$, GDP per capita growth, and I(Strong Governance). All regressions include industry-year fixed effects. For each independent variable, the top row shows the estimated coefficient and the bottom row shows the $t$-statistic. The $F$-test assesses the joint significance of the coefficients of SEER and SEER $\times$ I(Strong governance). ${ }^{* * *}$, **, and * indicate significance at the $1 \%, 5 \%$, and $10 \%$ level, respectively.

Panel A: Scope 1 Emissions

\begin{tabular}{|c|c|c|c|c|}
\hline Dependent variable: & $\begin{array}{c}\ln (1+\text { Global } \\
\text { emissions })\end{array}$ & $\begin{array}{c}\ln (1+\text { Home } \\
\text { emissions })\end{array}$ & $\begin{array}{l}\ln (1+\text { Foreign } \\
\text { emissions })\end{array}$ & $\begin{array}{c}\text { Foreign emissions } \\
\text { in \% of global } \\
\text { emissions }\end{array}$ \\
\hline Specification: & $\begin{array}{l}\text { OLS } \\
\text { (1) }\end{array}$ & $\begin{array}{l}\text { Tobit } \\
\text { (2) }\end{array}$ & $\begin{array}{l}\text { Tobit } \\
\text { (3) }\end{array}$ & $\begin{array}{c}\text { Tobit } \\
\text { (4) }\end{array}$ \\
\hline SEER & $\begin{array}{l}-0.13^{*} \\
(-1.90)\end{array}$ & $\begin{array}{l}-0.22 * \\
(-1.95)\end{array}$ & $\begin{array}{c}0.41^{* * *} \\
(2.88)\end{array}$ & $\begin{array}{l}3.44^{* *} \\
(2.51)\end{array}$ \\
\hline SEER $\times I$ (Strong governance) & $\begin{array}{l}-0.02 \\
(-0.12)\end{array}$ & $\begin{array}{c}-0.77 * * * \\
(-2.66)\end{array}$ & $\begin{array}{c}-0.29 \\
(-1.43)\end{array}$ & $\begin{array}{l}5.42 * * \\
(2.19)\end{array}$ \\
\hline $\begin{array}{l}\text { Controls } \\
\text { Fixed effects }\end{array}$ & Yes & Yes & Yes & Yes \\
\hline Industry $\times$ Year & Yes & Yes & Yes & Yes \\
\hline F-test & 1.42 & $11.55^{* * *}$ & 0.47 & $14.18^{* * *}$ \\
\hline $\begin{array}{l}\text { Adjusted/Pseudo R-squared } \\
\text { Observations } \\
\text { of which censored at } 0 \\
\text { of which censored at } 100\end{array}$ & $\begin{array}{l}0.683 \\
4,376\end{array}$ & $\begin{array}{c}0.123 \\
4,376 \\
196\end{array}$ & $\begin{array}{c}0.125 \\
4,376 \\
406\end{array}$ & $\begin{array}{c}0.0616 \\
4,376 \\
406 \\
196\end{array}$ \\
\hline
\end{tabular}

\section{Panel B: Scope 2 Emissions}

\begin{tabular}{|c|c|c|c|c|}
\hline Dependent variable: & $\begin{array}{l}\ln (1+\text { Global } \\
\text { emissions })\end{array}$ & $\begin{array}{l}\ln (1+\text { Home } \\
\text { emissions })\end{array}$ & $\begin{array}{l}\ln (1+\text { Foreign } \\
\text { emissions })\end{array}$ & $\begin{array}{l}\text { Foreign emissions } \\
\text { in \% of global } \\
\text { emissions }\end{array}$ \\
\hline Specification: & $\begin{array}{l}\text { OLS } \\
\text { (1) }\end{array}$ & $\begin{array}{l}\text { Tobit } \\
\text { (2) }\end{array}$ & $\begin{array}{l}\text { Tobit } \\
\text { (3) }\end{array}$ & $\begin{array}{c}\text { Tobit } \\
\text { (4) }\end{array}$ \\
\hline SEER & $\begin{array}{c}-0.16 * * * \\
(-2.92)\end{array}$ & $\begin{array}{c}-0.36 * * * \\
(-3.60)\end{array}$ & $\begin{array}{c}0.38^{* * * *} \\
(3.01)\end{array}$ & $\begin{array}{c}6.41 * * * \\
(4.92)\end{array}$ \\
\hline SEER ×I(Strong governance) & $\begin{array}{c}-0.07 \\
(-0.74)\end{array}$ & $\begin{array}{l}-0.62 * \\
(-1.95)\end{array}$ & $\begin{array}{c}-0.19 \\
(-1.04)\end{array}$ & $\begin{array}{l}5.06^{*} \\
(1.96)\end{array}$ \\
\hline $\begin{array}{l}\text { Controls } \\
\text { Fixed effects }\end{array}$ & Yes & Yes & Yes & Yes \\
\hline Industry $\times$ Year & Yes & Yes & Yes & Yes \\
\hline F-test & $6.99 * * *$ & $10.17 * * *$ & 1.81 & $23.28 * * *$ \\
\hline $\begin{array}{l}\text { Adjusted/Pseudo R-squared } \\
\text { Observations } \\
\text { of which censored at } 0 \\
\text { of which censored at } 100\end{array}$ & $\begin{array}{l}0.568 \\
4,442\end{array}$ & $\begin{array}{c}0.0910 \\
4,442 \\
159\end{array}$ & $\begin{array}{c}0.117 \\
4,442 \\
353\end{array}$ & $\begin{array}{c}0.0630 \\
4,442 \\
353 \\
159\end{array}$ \\
\hline
\end{tabular}




\section{Table 8. Environmental Regulation and Pollution-Intensive Industries}

The table shows the relationship between the domestic environmental policy and firms' emissions by industry. Panels A and B show results for Scope 1 and 2 emissions, respectively. Results are estimated from ordinary least squares (Column (1)) and Tobit (Columns (2)-(4)) regressions with standard errors clustered by firm. Controls include $\ln$ (Assets), Foreign asset share, $\ln (G D P)$, and GDP per capita growth. All regressions include industry-year fixed effects. For each independent variable, the top row shows the estimated coefficient and the bottom row shows the $t$ statistic. The $F$-test assesses the joint significance of the coefficients of SEER and SEER $\times$ I(Pollution intensive). ***, **, and * indicate significance at the $1 \%, 5 \%$, and $10 \%$ level, respectively.

\section{Panel A: Scope 1 Emissions}

\begin{tabular}{|c|c|c|c|c|}
\hline Dependent variable: & $\begin{array}{c}\ln (1+\text { Global } \\
\text { emissions })\end{array}$ & $\begin{array}{l}\ln (1+\text { Home } \\
\text { emissions })\end{array}$ & $\begin{array}{c}\ln (1+\text { Foreign } \\
\text { emissions })\end{array}$ & $\begin{array}{c}\text { Foreign emissions } \\
\text { in \% of global } \\
\text { emissions }\end{array}$ \\
\hline Specification: & $\begin{array}{c}\text { OLS } \\
(1) \\
\end{array}$ & $\begin{array}{c}\text { Tobit } \\
(2)\end{array}$ & $\begin{array}{c}\text { Tobit } \\
(3)\end{array}$ & $\begin{array}{c}\text { Tobit } \\
(4) \\
\end{array}$ \\
\hline SEER & $\begin{array}{c}-0.20 * * * \\
(-3.23)\end{array}$ & $\begin{array}{c}-0.39 * * * \\
(-3.35)\end{array}$ & $\begin{array}{l}0.25^{* *} \\
(2.25)\end{array}$ & $\begin{array}{c}3.76^{* * *} \\
(2.95)\end{array}$ \\
\hline SEER $\times$ I(Pollution intensive $)$ & $\begin{array}{c}0.30^{* * *} \\
(4.94)\end{array}$ & $\begin{array}{c}0.29^{* * *} \\
(2.64)\end{array}$ & $\begin{array}{l}0.27^{* *} \\
(2.25)\end{array}$ & $\begin{array}{l}-0.19 \\
(-0.15)\end{array}$ \\
\hline $\begin{array}{l}\text { Controls } \\
\text { Fixed effects }\end{array}$ & Yes & Yes & Yes & Yes \\
\hline Industry $\times$ Year & Yes & Yes & Yes & Yes \\
\hline F-test & 1.66 & 0.33 & $10.78 * * *$ & $4.11^{* *}$ \\
\hline $\begin{array}{l}\text { Observations } \\
\text { Adjusted/Pseudo R-squared } \\
\text { of which censored at } 0 \\
\text { of which censored at } 100\end{array}$ & $\begin{array}{l}4,559 \\
0.668\end{array}$ & $\begin{array}{c}4,559 \\
0.111 \\
216\end{array}$ & $\begin{array}{c}4,559 \\
0.125 \\
431\end{array}$ & $\begin{array}{c}4,559 \\
0.056 \\
431 \\
216\end{array}$ \\
\hline
\end{tabular}

Panel B: Scope 2 Emissions

\begin{tabular}{|c|c|c|c|c|}
\hline Dependent variable: & $\begin{array}{c}\ln (1+\text { Global } \\
\text { emissions })\end{array}$ & $\begin{array}{l}\ln (1+\text { Home } \\
\text { emissions })\end{array}$ & $\begin{array}{c}\ln (1+\text { Foreign } \\
\text { emissions })\end{array}$ & $\begin{array}{c}\text { Foreign emissions } \\
\text { in \% of global } \\
\text { emissions }\end{array}$ \\
\hline Specification: & $\begin{array}{c}\text { OLS } \\
(1)\end{array}$ & $\begin{array}{c}\text { Tobit } \\
(2)\end{array}$ & $\begin{array}{c}\text { Tobit } \\
\text { (3) }\end{array}$ & $\begin{array}{c}\text { Tobit } \\
\text { (4) }\end{array}$ \\
\hline SEER & $\begin{array}{c}-0.23 * * * \\
(-5.02)\end{array}$ & $\begin{array}{c}-0.52 * * * \\
(-5.09)\end{array}$ & $\begin{array}{c}0.31^{* * *} \\
(3.17)\end{array}$ & $\begin{array}{c}7.03^{* * * *} \\
(5.94)\end{array}$ \\
\hline SEER $\times I($ Pollution intensive $)$ & $\begin{array}{c}0.13^{* * *} \\
(2.60)\end{array}$ & $\begin{array}{c}0.12 \\
(1.45)\end{array}$ & $\begin{array}{c}0.23 * * \\
(2.34)\end{array}$ & $\begin{array}{c}0.26 \\
(0.25)\end{array}$ \\
\hline $\begin{array}{l}\text { Controls } \\
\text { Fixed effects }\end{array}$ & Yes & Yes & Yes & Yes \\
\hline Industry $\times$ Year & Yes & Yes & Yes & Yes \\
\hline F-test & 2.39 & $8.96^{* * *}$ & $16.17 * * *$ & $22.09 * * *$ \\
\hline $\begin{array}{l}\text { Adjusted/Pseudo R-squared } \\
\text { Observations } \\
\text { of which censored at } 0 \\
\text { of which censored at } 100\end{array}$ & $\begin{array}{l}0.590 \\
4,724\end{array}$ & $\begin{array}{c}0.093 \\
4,724 \\
184 \\
0\end{array}$ & $\begin{array}{c}0.115 \\
4,724 \\
380 \\
0\end{array}$ & $\begin{array}{c}0.057 \\
4,724 \\
380 \\
184\end{array}$ \\
\hline
\end{tabular}




\section{Appendix Table 1. Variable Definitions and Sources}

\section{Panel A: Variables Used in Firm-Level Analyses}

\begin{tabular}{|c|c|c|c|}
\hline Variable & Description & Units & Data Source \\
\hline \multicolumn{4}{|l|}{ Dependent variables } \\
\hline Global emissions & $\begin{array}{l}\text { Firm i's } \mathrm{CO}_{2} \text { emissions globally in year } t \text {, calculated for either } \\
\text { Scope } 1 \text {, Scope } 2 \text {, or Scope } 3 \text { emissions }\end{array}$ & tons & CDP \\
\hline Home emissions & $\begin{array}{l}\text { Firm i's } \mathrm{CO}_{2} \text { emissions in home country in year } t \text {, calculated } \\
\text { for either Scope } 1 \text { or Scope } 2 \text { emissions }\end{array}$ & tons & CDP \\
\hline Foreign emissions & $\begin{array}{l}\text { Firm i's } \mathrm{CO}_{2} \text { emissions in all foreign countries combined in } \\
\text { year } t \text {, calculated for either Scope } 1 \text { or Scope } 2 \text { emissions }\end{array}$ & tons & CDP \\
\hline $\begin{array}{l}\text { Foreign emissions } \\
\text { in \% of global } \\
\text { emissions }\end{array}$ & $\begin{array}{l}\text { Firm } i \text { 's } \mathrm{CO}_{2} \text { emissions in all foreign countries combined in } \\
\text { year } t \text { in percent of firm } i \text { 's global } \mathrm{CO}_{2} \text { emissions in year } t \text {, } \\
\text { calculated for either Scope } 1 \text { or Scope } 2 \text { emissions }\end{array}$ & $0-100 \%$ & CDP \\
\hline \multicolumn{4}{|l|}{ Independent variables } \\
\hline SER & $\begin{array}{l}\text { Stringency of environmental regulation in firm } i \text { 's home } \\
\text { country in year } t\end{array}$ & $1-7$ & $\begin{array}{l}\text { World Economic } \\
\text { Forum }\end{array}$ \\
\hline EER & $\begin{array}{l}\text { Enforcement of environmental regulation in firm } i \text { 's home } \\
\text { country in year } t\end{array}$ & $1-7$ & $\begin{array}{l}\text { World Economic } \\
\text { Forum }\end{array}$ \\
\hline SEER & $\begin{array}{l}\text { Stringency and enforcement of environmental regulation in } \\
\text { firm } i \text { 's home country in year } t \text {; calculated as SEER = } \\
(\text { SER*EER) } / 7\end{array}$ & $0.14-7$ & $\begin{array}{l}\text { World Economic } \\
\text { Forum }\end{array}$ \\
\hline Tightening SEER & $\begin{array}{l}\operatorname{Max}\left(0, \Delta \mathrm{SEER}_{\mathrm{t}}\right) \text {, where } \triangle \mathrm{SEER}_{\mathrm{t}} \text { is the change in the } \\
\text { environmental regulation index in firm } i \text { 's home country in } \\
\text { year } t\left(\mathrm{SEER}_{\mathrm{t}}\right) \text {, relative to the index of each country in the } \\
\text { first year covered during the sample period }\left(\mathrm{SEER}_{0}\right) \text {. }\end{array}$ & & $\begin{array}{l}\text { World Economic } \\
\text { Forum }\end{array}$ \\
\hline Weakening SEER & $\begin{array}{l}\operatorname{Min}\left(\triangle \mathrm{SEER}_{\mathrm{t}}, 0\right) \text {, where } \triangle \mathrm{SEER} \mathrm{R}_{\mathrm{t}} \text { is the change in the } \\
\text { environmental regulation index in firm } i \text { 's home country in } \\
\text { year } t\left(\mathrm{SEER}_{\mathrm{t}}\right) \text {, relative to the index of each country in the } \\
\text { first year covered during the sample period }(\mathrm{SEER}) \text {. }\end{array}$ & & $\begin{array}{l}\text { World Economic } \\
\text { Forum }\end{array}$ \\
\hline Assets & Total assets of firm $i$ in year $t$ (WC02999) & US\$ mil & Worldscope \\
\hline Foreign asset share & $\begin{array}{l}\text { Firm i's foreign assets in \% of total assets in year } t \\
\text { (WC08736) }\end{array}$ & $0-100 \%$ & Worldscope \\
\hline I(Strong governance) & $\begin{array}{l}\text { Dummy equal to } 1 \text { if firm } i \text { 's corporate governance score } \\
\text { (CGVSCORE) in year } t \text { is larger than the sample median, } 0 \\
\text { otherwise }\end{array}$ & $0 / 1$ & Asset4 \\
\hline I(Pollution intensive) & $\begin{array}{l}\text { Dummy equal to } 1 \text { if firm } i \text { belongs to pollution-intensive } \\
\text { industry, } 0 \text { otherwise; industries with NACE Industries Codes } \\
\text { (Revision 2) C19, C23, C24, D, H50 and H51 are considered } \\
\text { to be pollution-intensive industry; the NACE code is mapped } \\
\text { to the firm's NAICS code using the Index Correspondent } \\
\text { Tables provided by Eurostat, RAMON (Reference And } \\
\text { Management of Nomenclatures) }\end{array}$ & $0 / 1$ & Compustat, Eurostat \\
\hline GDP & Gross domestic product of firm i's home country in year $t$ & $\begin{array}{l}\text { Current } \\
\text { US\$ mil }\end{array}$ & $\begin{array}{l}\text { World Bank's World } \\
\text { Development } \\
\text { Indicators }\end{array}$ \\
\hline GDP per capita growth & $\begin{array}{l}\text { Annual percentage growth rate of GDP per capita of firm i's } \\
\text { home country in year } t\end{array}$ & $0-100 \%$ & $\begin{array}{l}\text { World Bank's World } \\
\text { Development } \\
\text { Indicators }\end{array}$ \\
\hline
\end{tabular}

(continues on next page) 


\section{Appendix Table 1. Variable Definitions and Sources (Cont.) Panel A: Variables Used in Firm-Level Analyses (Cont.)}

\begin{tabular}{|c|c|c|}
\hline CA(Skill) & $\begin{array}{l}\text { The comparative advantage in skilled labor }\left(h_{s} H_{c}\right) \text {, where } h_{s} \\
\text { denotes the skill intensity of production in the firm's industry } \\
\text { s and } H_{c} \text { denotes endowment in skilled labor in country }(c) \text {. } \\
\text { Skill intensity } h_{s} \text { is the ratio of non-production worker wages } \\
\text { to total wages in industry } s \text { in the United States, averaged } \\
\text { across the period } 2008 \text { to } 2011 \text {. Industries are identified based } \\
\text { on SIC codes. A country's skilled labor endowment } H_{c} \text { is } \\
\text { measured as the natural log of the ratio of the population aged } \\
25 \text { or above that completed secondary education to those that } \\
\text { did not complete secondary education. Data for factor } \\
\text { intensity } h_{s} \text { is obtained from the NBER-CES Manufacturing } \\
\text { Industry Database, which contains annual data up to } 2011 \text {. } \\
\text { Data for skilled labor endowment Hc are obtained from the } \\
\text { Barro-Lee Educational Attainment Dataset. }\end{array}$ & $\begin{array}{l}\text { NBER-CES } \\
\text { Manufacturing } \\
\text { Industry Database } \\
\text { (http://data.nber.org/ } \\
\text { nberces), Barro-Lee } \\
\text { Educational } \\
\text { Attainment Dataset } \\
\text { (http://barrolee.com) }\end{array}$ \\
\hline CA(Capital) & $\begin{array}{l}\text { The comparative advantage in capital }\left(k_{s} K_{c}\right) \text {, where } k_{s} \text { denotes } \\
\text { the capital intensity of production in the firm's industry s and } \\
K_{c} \text { denotes endowment in capital in country }(c) \text {. Capital } \\
\text { intensity } k_{s} \text { is the real capital stock in industry i divided by } \\
\text { the value added in industry i in the United States averaged } \\
\text { across the period } 2008 \text { to } 2011 \text {. Industries are identified based } \\
\text { on SIC codes. A country's capital endowment } K_{c} \text { is the } \\
\text { natural log of the capital stock per worker averaged across the } \\
\text { period } 2008 \text { to } 2015 \text {. Data for factor intensity } k_{s} \text { is obtained } \\
\text { from the NBER-CES Manufacturing Industry Database, } \\
\text { which contains annual data up to } 2011 \text {. Data for capital } \\
\text { endowment } K_{c} \text { are obtained from the Penn World Tables. }\end{array}$ & $\begin{array}{l}\text { NBER-CES } \\
\text { Manufacturing } \\
\text { Industry Database } \\
\text { (http://data.nber.org/ } \\
\text { nberces), the Penn } \\
\text { World Tables } \\
\text { (https://www.rug.nl/ } \\
\text { ggdc/productivity/p } \\
\text { wt) }\end{array}$ \\
\hline
\end{tabular}




\section{Appendix Table 1. Variable Definitions and Sources (Cont.)}

\section{Panel B: Variables Used in Firm-Country-Level Analyses}

\begin{tabular}{|c|c|c|c|}
\hline Variable & Description & Units & Data Source \\
\hline \multicolumn{4}{|l|}{ Dependent variables } \\
\hline Foreign emissions & $\begin{array}{l}\text { Firm i's } \mathrm{CO}_{2} \text { emissions in foreign country } c \text { in year } t \text {, } \\
\text { calculated for either Scope } 1 \text { or Scope } 2 \text { emissions }\end{array}$ & tons & CDP \\
\hline $\begin{array}{l}\text { Foreign emissions } \\
\text { in \% of global } \\
\text { emissions }\end{array}$ & $\begin{array}{l}\text { Firm i's } \mathrm{CO}_{2} \text { emissions in foreign country } c \text { in year } t \text { in } \\
\text { percent of firm i's global } \mathrm{CO}_{2} \text { emissions in year } t \text {, calculated } \\
\text { for either Scope } 1 \text { or Scope } 2 \text { emissions }\end{array}$ & $0-100 \%$ & CDP \\
\hline \multicolumn{4}{|l|}{ Independent variables } \\
\hline $\mathrm{SEER}_{\text {home }}-\mathrm{SEER}_{\text {foreign }}$ & $\begin{array}{l}\text { Difference between stringency and enforcement of } \\
\text { environmental regulation in firm } i \text { 's home country and foreign } \\
\text { country in year } t \text {; each country's SEER is calculated as SEER } \\
=(\text { SER*EER }) / 7\end{array}$ & -7 to +7 & $\begin{array}{l}\text { World Economic } \\
\text { Forum }\end{array}$ \\
\hline Assets & Total assets of firm $i$ in year $t$ (WC02999) & US\$ mil & Worldscope \\
\hline Foreign asset share & $\begin{array}{l}\text { Firm } i \text { 's foreign assets in \% of total assets in year } t \\
\text { (WC08736) }\end{array}$ & $0-100 \%$ & Worldscope \\
\hline GDP & Gross domestic product in foreign country $c$ in year $t$ & $\begin{array}{l}\text { current } \\
\text { US\$ mil }\end{array}$ & $\begin{array}{l}\text { World Bank's World } \\
\text { Development } \\
\text { Indicators }\end{array}$ \\
\hline Geographic distance & $\begin{array}{l}\text { Geographic distance between firm i's home country and } \\
\text { foreign country, measured using the great circle distance } \\
\text { formula }\end{array}$ & $\mathrm{km}$ & $\begin{array}{l}\text { www.distancefromt } \\
\underline{\text { o.net }}\end{array}$ \\
\hline Common border & $\begin{array}{l}\text { Dummy equal to } 1 \text { if firm } i \text { 's home country and the foreign } \\
\text { country } c \text { share a land border, } 0 \text { otherwise }\end{array}$ & $0 / 1$ & $\begin{array}{l}\text { Glick and Rose } \\
\text { (2016), CIA World } \\
\text { Factbook }\end{array}$ \\
\hline $\begin{array}{l}\text { Common colonial } \\
\text { history }\end{array}$ & $\begin{array}{l}\text { Dummy equal to } 1 \text { if firm } i \text { 's home country and foreign } \\
\text { country } c \text { have a colonial history or belonged to same } \\
\text { country, } 0 \text { otherwise }\end{array}$ & $0 / 1$ & $\begin{array}{l}\text { Glick and Rose } \\
\text { (2016) }\end{array}$ \\
\hline Trade & $\begin{array}{l}\text { Sum of exports and imports between firm } i \text { 's home country } \\
\text { and foreign country } c \text { in year } t\end{array}$ & US\$ & $\begin{array}{l}\text { IMF's Direction of } \\
\text { Trade Statistics }\end{array}$ \\
\hline
\end{tabular}

\section{Panel C: Fixed Effects Used in Firm-Level and Firm-Country-Level Analyses}

\begin{tabular}{llll}
\hline Variable & Description & Units & Data Source \\
\hline Year & Dummies identifying the year $t$ in which firm $i$ emits $\mathrm{CO}_{2}$, & $0 / 1$ & CDP \\
& $2008-2015$ & & Worldscope \\
Industry & Dummies based on 2-digit SIC codes (WC07021) & $0 / 1$ & CDP \\
Home country & $\begin{array}{l}\text { Dummies identifying the home country } h \text { in which firm } i \text { is } \\
\text { headquartered }\end{array}$ & $0 / 1$ & CDP \\
Foreign country & $\begin{array}{l}\text { Dummies identifying the foreign country } c \text { in which firm } i \\
\text { emits } \mathrm{CO}_{2}\end{array}$ & $0 / 1$ & \\
\hline
\end{tabular}




\section{Appendix Table 2. Pollution-Intensive Industries}

The table presents summary statistics about the pollution intensity of industries and firms in pollution-intensive versus non-pollution-intensive industries. Panel A shows the $\mathrm{CO}_{2}$ intensity of various industries in the European Union (2018 member states). $\mathrm{CO}_{2}$ intensity is measured as the kilograms of $\mathrm{CO}_{2}$ per euro of gross value added. For comparability over time, gross value added is measured in real terms (chain linked volumes at 2010 prices) to eliminate the effects of inflation. Pollution-intensive industries are marked with an asterisk and bold face. Source: Eurostat, Air emission accounts, Air emissions intensities by NACE Rev. 2 activity (env_ac_aeint_r2):

http://ec.europa.eu/eurostat/web/environment/emissions-of-greenhouse-gases-and-air-pollutants/air-emissionaccounts/database. Panel B presents summary statistics for all firms that could be mapped into the NACE industries.

\section{Panel A: Industry $\mathrm{CO}_{2}$ Emission Intensity (kg per Euro), by Year}

\begin{tabular}{|c|c|c|c|c|c|c|c|c|}
\hline NACE Industry Code (Revision 2) & 2008 & 2009 & 2010 & 2011 & 2012 & 2013 & 2014 & 2015 \\
\hline TOTAL - Total - all NACE activities & 0.30 & 0.28 & 0.28 & 0.27 & 0.27 & 0.26 & 0.24 & 0.24 \\
\hline A - Agriculture, forestry and fishing & 0.55 & 0.54 & 0.57 & 0.55 & 0.58 & 0.56 & 0.53 & 0.52 \\
\hline A01 - Crop and animal production, hunting and related service activities & 0.56 & 0.55 & 0.59 & 0.57 & 0.60 & 0.58 & 0.55 & 0.54 \\
\hline A02 - Forestry and logging & 0.22 & 0.21 & 0.22 & 0.20 & 0.19 & 0.19 & 0.17 & 0.18 \\
\hline A03 - Fishing and aquaculture & 1.27 & 1.23 & 1.19 & 1.24 & 1.23 & 1.21 & 1.11 & 1.11 \\
\hline B - Mining and quarrying & 0.54 & 0.54 & 0.53 & 0.55 & 0.51 & 0.52 & 0.53 & 0.53 \\
\hline C - Manufacturing & 0.54 & 0.53 & 0.51 & 0.48 & 0.47 & 0.45 & 0.44 & 0.42 \\
\hline C10-C12 - Manufacture of food products; beverages and tobacco products & 0.28 & 0.26 & 0.26 & 0.24 & 0.25 & 0.24 & 0.23 & 0.21 \\
\hline C13-C15 - Manufacture of textiles, wearing apparel, leather and related products & 0.16 & 0.16 & 0.15 & 0.14 & 0.14 & 0.14 & 0.13 & 0.14 \\
\hline $\begin{array}{l}\text { C16 - Manufacture of wood and of products of wood and cork, except furniture; } \\
\text { manufacture of articles of straw and plaiting materials }\end{array}$ & 0.22 & 0.20 & 0.19 & 0.17 & 0.17 & 0.17 & 0.16 & 0.15 \\
\hline C17 - Manufacture of paper and paper products & 0.86 & 0.83 & 0.83 & 0.80 & 0.74 & 0.74 & 0.69 & 0.70 \\
\hline C18 - Printing and reproduction of recorded media & 0.09 & 0.08 & 0.09 & 0.08 & 0.08 & 0.09 & 0.08 & 0.09 \\
\hline C19 - Manufacture of coke and refined petroleum products* & 5.91 & 5.26 & 5.80 & 5.84 & 7.34 & 5.93 & 5.36 & 3.59 \\
\hline C20 - Manufacture of chemicals and chemical products & 1.32 & 1.30 & 1.26 & 1.23 & 1.23 & 1.20 & 1.12 & 1.04 \\
\hline C21 - Manufacture of basic pharmaceutical products and pharmaceutical preparations & 0.07 & 0.06 & 0.06 & 0.06 & 0.06 & 0.06 & 0.05 & 0.05 \\
\hline C22 - Manufacture of rubber and plastic products & 0.17 & 0.15 & 0.16 & 0.13 & 0.13 & 0.15 & 0.14 & 0.14 \\
\hline C23 - Manufacture of other non-metallic mineral products* & 3.36 & 3.31 & 3.27 & 3.09 & 3.03 & 2.97 & 2.92 & 2.92 \\
\hline C24 - Manufacture of basic metals* & 3.23 & 2.90 & 3.08 & 2.86 & 2.55 & 2.43 & 2.31 & 2.21 \\
\hline C25 - Manufacture of fabricated metal products, except machinery and equipment & 0.09 & 0.11 & 0.10 & 0.09 & 0.09 & 0.09 & 0.08 & 0.09 \\
\hline C26 - Manufacture of computer, electronic and optical products & 0.03 & 0.03 & 0.03 & 0.03 & 0.03 & 0.03 & 0.02 & 0.03 \\
\hline C27 - Manufacture of electrical equipment & 0.05 & 0.06 & 0.05 & 0.05 & 0.05 & 0.05 & 0.05 & 0.05 \\
\hline C28 - Manufacture of machinery and equipment n.e.c. & 0.05 & 0.06 & 0.05 & 0.05 & 0.04 & 0.05 & 0.04 & 0.04 \\
\hline C29 - Manufacture of motor vehicles, trailers and semi-trailers & 0.07 & 0.08 & 0.07 & 0.06 & 0.06 & 0.06 & 0.05 & 0.05 \\
\hline C30 - Manufacture of other transport equipment & 0.06 & 0.06 & 0.06 & 0.05 & 0.04 & 0.04 & 0.04 & 0.04 \\
\hline C31+C32 - Manufacture of furniture; other manufacturing & 0.08 & 0.07 & 0.07 & 0.06 & 0.06 & 0.06 & 0.06 & 0.06 \\
\hline C33 - Repair and installation of machinery and equipment & 0.03 & 0.03 & 0.03 & 0.03 & 0.03 & 0.03 & 0.03 & 0.03 \\
\hline D - Electricity, gas, steam and air conditioning supply* & 6.29 & 5.69 & 5.70 & 5.91 & 5.63 & 5.56 & 5.26 & 5.24 \\
\hline E - Water supply; sewerage, waste management and remediation activities & 0.37 & 0.36 & 0.37 & 0.35 & 0.34 & 0.35 & 0.35 & 0.34 \\
\hline E36 - Water collection, treatment and supply & 0.22 & 0.21 & 0.19 & 0.17 & 0.17 & 0.18 & 0.18 & 0.18 \\
\hline E37-E39 - Sewerage, waste management, remediation activities & 0.43 & 0.42 & 0.43 & 0.41 & 0.41 & 0.41 & 0.41 & 0.40 \\
\hline F - Construction & 0.08 & 0.08 & 0.09 & 0.09 & 0.09 & 0.09 & 0.09 & 0.09 \\
\hline G - Wholesale and retail trade; repair of motor vehicles and motorcycles & 0.06 & 0.06 & 0.06 & 0.06 & 0.06 & 0.06 & 0.05 & 0.05 \\
\hline G45 - Wholesale and retail trade and repair of motor vehicles and motorcycles & 0.07 & 0.07 & 0.07 & 0.06 & 0.06 & 0.06 & 0.06 & 0.06 \\
\hline G46 - Wholesale trade, except of motor vehicles and motorcycles & 0.06 & 0.06 & 0.06 & 0.06 & 0.06 & 0.05 & 0.05 & 0.05 \\
\hline G47 - Retail trade, except of motor vehicles and motorcycles & 0.06 & 0.06 & 0.06 & 0.06 & 0.06 & 0.06 & 0.05 & 0.05 \\
\hline H - Transportation and storage & 0.90 & 0.88 & 0.87 & 0.85 & 0.83 & 0.82 & 0.81 & 0.83 \\
\hline H49 - Land transport and transport via pipelines & 0.79 & 0.78 & 0.78 & 0.75 & 0.72 & 0.73 & 0.72 & 0.72 \\
\hline H50 - Water transport* & 3.37 & 3.39 & 3.40 & 3.43 & 3.26 & 3.01 & 3.25 & 3.66 \\
\hline H51 - Air transport* & 4.10 & 4.47 & 3.93 & 3.88 & 3.74 & 3.70 & 4.10 & 4.35 \\
\hline H52 - Warehousing and support activities for transportation & 0.12 & 0.12 & 0.12 & 0.12 & 0.12 & 0.12 & 0.12 & 0.12 \\
\hline H53 - Postal and courier activities & 0.11 & 0.11 & 0.12 & 0.11 & 0.11 & 0.12 & 0.12 & 0.13 \\
\hline
\end{tabular}




\title{
Appendix Table 2. Pollution-Intensive Industries (Cont.)
}

\author{
(continues from previous page)
}

\begin{tabular}{|c|c|c|c|c|c|c|c|c|}
\hline NACE Industry Code (Revision 2) & 2008 & 2009 & 2010 & 2011 & 2012 & 2013 & 2014 & 2015 \\
\hline I - Accommodation and food service activities & 0.06 & 0.06 & 0.07 & 0.06 & 0.06 & 0.06 & 0.05 & 0.05 \\
\hline $\mathrm{J}$ - Information and communication & 0.02 & 0.02 & 0.02 & 0.02 & 0.02 & 0.02 & 0.02 & 0.01 \\
\hline J58 - Publishing activities & 0.03 & 0.03 & 0.03 & 0.03 & 0.03 & 0.03 & 0.03 & 0.02 \\
\hline J59+J60 - Motion picture, video, television programme production; programming and b & 0.03 & 0.03 & 0.03 & 0.02 & 0.02 & 0.02 & 0.02 & 0.02 \\
\hline J61 - Telecommunications & 0.02 & 0.02 & 0.02 & 0.02 & 0.01 & 0.01 & 0.01 & 0.01 \\
\hline J62+J63 - Computer programming, consultancy, and information service activities & 0.02 & 0.02 & 0.02 & 0.02 & 0.02 & 0.02 & 0.01 & 0.01 \\
\hline K - Financial and insurance activities & 0.01 & 0.01 & 0.01 & 0.01 & 0.01 & 0.01 & 0.01 & 0.01 \\
\hline K64 - Financial service activities, except insurance and pension funding & 0.01 & 0.01 & 0.01 & 0.01 & 0.01 & 0.01 & 0.01 & 0.01 \\
\hline K65 - Insurance, reinsurance and pension funding, except compulsory social security & 0.01 & 0.01 & 0.01 & 0.01 & 0.01 & 0.01 & 0.01 & 0.01 \\
\hline K66 - Activities auxiliary to financial services and insurance activities & 0.02 & 0.02 & 0.02 & 0.02 & 0.02 & 0.02 & 0.01 & 0.01 \\
\hline L - Real estate activities & 0.01 & 0.01 & 0.01 & 0.00 & 0.00 & 0.00 & 0.00 & 0.00 \\
\hline \multicolumn{9}{|l|}{ M - Professional, scientific and technical activities } \\
\hline $\begin{array}{l}\text { M69+M70 - Legal and accounting activities; activities of head offices; management } \\
\text { consultancy activities }\end{array}$ & 0.03 & 0.03 & 0.02 & 0.02 & 0.02 & 0.02 & 0.02 & 0.02 \\
\hline M71 - Architectural and engineering activities; technical testing and analysis & 0.03 & 0.03 & 0.03 & 0.03 & 0.03 & 0.03 & 0.02 & 0.02 \\
\hline M72 - Scientific research and development & 0.03 & 0.03 & 0.04 & 0.04 & 0.04 & 0.04 & 0.04 & 0.04 \\
\hline M73 - Advertising and market research & 0.03 & 0.04 & 0.03 & 0.03 & 0.03 & 0.03 & 0.02 & 0.02 \\
\hline M74+M75 - Other professional, scientific and technical activities; veterinary activities & 0.03 & 0.04 & 0.03 & 0.03 & 0.03 & 0.03 & 0.03 & 0.03 \\
\hline $\mathrm{N}$ - Administrative and support service activities & 0.05 & 0.05 & 0.05 & 0.05 & 0.05 & 0.05 & 0.04 & 0.04 \\
\hline N77 - Rental and leasing activities & 0.10 & 0.10 & 0.09 & 0.09 & 0.09 & 0.09 & 0.08 & 0.08 \\
\hline N78 - Employment activities & 0.02 & 0.02 & 0.02 & 0.02 & 0.02 & 0.02 & 0.02 & 0.02 \\
\hline N79 - Travel agency, tour operator reservation service and related activities & 0.04 & 0.04 & 0.04 & 0.04 & 0.04 & 0.04 & 0.03 & 0.03 \\
\hline $\begin{array}{l}\text { N80-N82 - Security and investigation, service and landscape, office administrative and } \\
\text { support activities }\end{array}$ & 0.04 & 0.04 & 0.04 & 0.04 & 0.04 & 0.04 & 0.03 & 0.03 \\
\hline O - Public administration and defence; compulsory social security & 0.05 & 0.04 & 0.04 & 0.04 & 0.04 & 0.04 & 0.04 & 0.04 \\
\hline P - Education & 0.04 & 0.03 & 0.04 & 0.03 & 0.03 & 0.03 & 0.03 & 0.03 \\
\hline \multicolumn{9}{|l|}{ Q - Human health and social work activities } \\
\hline Q86 - Human health activities & 0.03 & 0.03 & 0.03 & 0.03 & 0.03 & 0.03 & 0.03 & 0.03 \\
\hline $\begin{array}{l}\text { Q87+Q88 - Residential care activities and social work activities without } \\
\text { accommodation }\end{array}$ & 0.04 & 0.04 & 0.04 & 0.04 & 0.04 & 0.04 & 0.03 & 0.04 \\
\hline $\mathrm{R}$ - Arts, entertainment and recreation & 0.05 & 0.05 & 0.05 & 0.05 & 0.05 & 0.05 & 0.04 & 0.04 \\
\hline $\begin{array}{l}\text { R90-R92 - Creative, arts and entertainment activities; libraries, archives, museums } \\
\text { and other cultural activities; gambling and betting activities }\end{array}$ & 0.04 & 0.04 & 0.04 & 0.04 & 0.04 & 0.04 & 0.03 & 0.03 \\
\hline R93 - Sports activities and amusement and recreation activities & 0.07 & 0.07 & 0.07 & 0.07 & 0.07 & 0.07 & 0.06 & 0.06 \\
\hline S - Other service activities & 0.06 & 0.05 & 0.05 & 0.05 & 0.05 & 0.05 & 0.04 & 0.05 \\
\hline S94 - Activities of membership organisations & 0.05 & 0.05 & 0.05 & 0.04 & 0.04 & 0.05 & 0.04 & 0.04 \\
\hline S95 - Repair of computers and personal and household goods & 0.06 & 0.06 & 0.07 & 0.06 & 0.06 & 0.06 & 0.06 & 0.06 \\
\hline S96 - Other personal service activities & 0.06 & 0.05 & 0.05 & 0.05 & 0.05 & 0.05 & 0.04 & 0.04 \\
\hline
\end{tabular}




\section{Appendix Table 2. Pollution-Intensive Industries (Cont.)}

Panel B: Summary Statistics: Pollution-Intensive vs. Non-Pollution-Intensive Industries

\begin{tabular}{|c|c|c|c|c|c|c|c|c|}
\hline & \multicolumn{4}{|c|}{ Pollution-Intensive Industry } & \multicolumn{4}{|c|}{ Non-Pollution-Intensive Industry } \\
\hline & $\mathrm{N}$ & Mean & Std Dev & Median & $\mathrm{N}$ & Mean & Std Dev & Median \\
\hline \multicolumn{9}{|l|}{ Scope $1 \mathrm{CO}_{2}$ emissions } \\
\hline Global emissions ('000 tons) & 296 & 13,941 & 28,585 & 3,100 & 4,263 & 883 & 3,501 & 64 \\
\hline Home emissions ('000 tons) & 296 & 5,763 & 11,096 & 1,425 & 4,263 & 478 & 1,882 & 24 \\
\hline Foreign emissions ('000 tons) & 296 & 8,178 & 26,955 & 760 & 4,263 & 406 & 2,468 & 12 \\
\hline $\begin{array}{l}\text { Foreign emissions } \\
\text { (\% of global emissions) }\end{array}$ & 296 & 40.56 & 33.99 & 35.69 & 4,263 & 40.08 & 34.72 & 32.48 \\
\hline \multicolumn{9}{|l|}{ Scope $2 \mathrm{CO}_{2}$ emissions } \\
\hline Global emissions ('000 tons) & 319 & 1,949 & 3,232 & 625 & 4,405 & 594 & 2,731 & 127 \\
\hline Home emissions ('000 tons) & 319 & 678 & 1,296 & 231 & 4,405 & 351 & 2,389 & 43 \\
\hline Foreign emissions ('000 tons) & 319 & 1,271 & 2,957 & 157 & 4,405 & 244 & 1,121 & 31 \\
\hline $\begin{array}{l}\text { Foreign emissions } \\
\text { (\% of global emissions) }\end{array}$ & 319 & 44.95 & 35.14 & 43.33 & 4,405 & 44.96 & 35.18 & 41.60 \\
\hline
\end{tabular}




\section{Appendix Table 3. SER versus EER}

The table presents evidence about the relation between emissions in foreign countries and home-country stringency and enforcement (SER and EER) of environmental policies. Panels A and C show Scope 1 emissions, and Panels B and D show Scope 2 emissions. Columns (1) and (2) are estimated with ordinary least squares, and Columns (3) to (8) are estimated as Tobit models. All regressions include $\ln$ (Assets), Foreign asset share, $\ln (G D P)$, GDP per capita growth, and industry-year fixed effects. Standard errors are clustered by firm. For each independent variable, the top row shows the estimated coefficient and the bottom row shows the $t$-statistic. $* * *,{ }^{* *}$, and $*$ indicate significance at the $1 \%, 5 \%$, and $10 \%$ level, respectively.

\section{Panel A: Scope 1 Emissions}

\begin{tabular}{|c|c|c|c|c|c|c|c|c|}
\hline \multirow[t]{2}{*}{ Dependent variable: } & \multicolumn{2}{|c|}{$\begin{array}{c}\ln (1+\text { Global } \\
\text { emissions })\end{array}$} & \multicolumn{2}{|c|}{$\begin{array}{c}\ln (1+\text { Home } \\
\text { emissions })\end{array}$} & \multicolumn{2}{|c|}{$\begin{array}{c}\ln (1+\text { Foreign } \\
\text { emissions })\end{array}$} & \multicolumn{2}{|c|}{$\begin{array}{c}\text { Foreign emissions } \\
\text { in \% of global } \\
\text { emissions } \\
\end{array}$} \\
\hline & $\begin{array}{l}\text { OLS } \\
(1)\end{array}$ & $\begin{array}{c}\text { OLS } \\
\text { (2) }\end{array}$ & $\begin{array}{l}\text { Tobit } \\
\text { (3) }\end{array}$ & $\begin{array}{c}\text { Tobit } \\
\text { (4) }\end{array}$ & $\begin{array}{l}\text { Tobit } \\
\text { (5) }\end{array}$ & $\begin{array}{c}\text { Tobit } \\
\text { (6) }\end{array}$ & $\begin{array}{c}\text { Tobit } \\
\text { (7) }\end{array}$ & $\begin{array}{c}\text { Tobit } \\
\text { (8) }\end{array}$ \\
\hline SER (stringency) & $\begin{array}{r}-0.25^{* * *} \\
(-2.62)\end{array}$ & & $\begin{array}{r}-0.48^{* * *} \\
(-2.70)\end{array}$ & & $\begin{array}{c}0.47 * * * \\
(2.60)\end{array}$ & & $\begin{array}{c}5.09 * * * \\
(2.66)\end{array}$ & \\
\hline EER (enforcement) & & $\begin{array}{l}-0.19 * * \\
(-2.47)\end{array}$ & & $\begin{array}{c}-0.47 * * * \\
(-3.43)\end{array}$ & & $\begin{array}{c}0.44 * * * \\
(2.99)\end{array}$ & & $\begin{array}{c}5.41 * * * \\
(3.49)\end{array}$ \\
\hline $\begin{array}{l}\text { Controls } \\
\text { Fixed effects }\end{array}$ & Yes & Yes & Yes & Yes & Yes & Yes & Yes & Yes \\
\hline Industry $\times$ Year & Yes & Yes & Yes & Yes & Yes & Yes & Yes & Yes \\
\hline Adjusted/Pseudo R-squared & 0.684 & 0.684 & 0.120 & 0.121 & 0.122 & 0.122 & 0.0569 & 0.0574 \\
\hline $\begin{array}{l}\text { Observations } \\
\text { of which censored at } 0 \\
\text { of which censored at } 100\end{array}$ & 4,919 & 4,919 & $\begin{array}{c}4,919 \\
226\end{array}$ & $\begin{array}{c}4,919 \\
226\end{array}$ & $\begin{array}{c}4,919 \\
481\end{array}$ & $\begin{array}{c}4,919 \\
481\end{array}$ & $\begin{array}{c}4,919 \\
481 \\
226\end{array}$ & $\begin{array}{c}4,919 \\
481 \\
226\end{array}$ \\
\hline
\end{tabular}

\section{Panel B: Scope 2 Emissions}

\begin{tabular}{|c|c|c|c|c|c|c|c|c|}
\hline \multirow[t]{2}{*}{ Dependent variable: } & \multicolumn{2}{|c|}{$\begin{array}{c}\ln (1+\text { Global } \\
\text { emissions })\end{array}$} & \multicolumn{2}{|c|}{$\begin{array}{c}\ln (1+\text { Home } \\
\text { emissions })\end{array}$} & \multicolumn{2}{|c|}{$\begin{array}{l}\ln (1+\text { Foreign } \\
\text { emissions) }\end{array}$} & \multicolumn{2}{|c|}{$\begin{array}{c}\text { Foreign emissions } \\
\text { in \% of global } \\
\text { emissions }\end{array}$} \\
\hline & $\begin{array}{c}\text { OLS } \\
(1) \\
\end{array}$ & $\begin{array}{c}\text { OLS } \\
(2) \\
\end{array}$ & $\begin{array}{c}\text { Tobit } \\
(3)\end{array}$ & $\begin{array}{c}\text { Tobit } \\
(4)\end{array}$ & $\begin{array}{c}\text { Tobit } \\
(5)\end{array}$ & $\begin{array}{c}\text { Tobit } \\
(6)\end{array}$ & $\begin{array}{c}\text { Tobit } \\
(7)\end{array}$ & $\begin{array}{c}\text { Tobit } \\
(8) \\
\end{array}$ \\
\hline SER (stringency) & $\begin{array}{c}-0.31 * * * \\
(-4.36)\end{array}$ & & $\begin{array}{c}-0.66 * * * \\
(-4.07)\end{array}$ & & $\begin{array}{c}0.57 * * * \\
(3.55)\end{array}$ & & $\begin{array}{c}10.38 * * * \\
(5.76)\end{array}$ & \\
\hline EER (enforcement) & & $\begin{array}{c}-0.24 * * * \\
(-3.92)\end{array}$ & & $\begin{array}{c}-0.64 * * * \\
(-4.88)\end{array}$ & & $\begin{array}{c}0.50 * * * \\
(3.88)\end{array}$ & & $\begin{array}{c}9.84 * * * \\
(6.58)\end{array}$ \\
\hline $\begin{array}{l}\text { Controls } \\
\text { Fixed effects }\end{array}$ & Yes & Yes & Yes & Yes & Yes & Yes & Yes & Yes \\
\hline Industry × Year & Yes & Yes & Yes & Yes & Yes & Yes & Yes & Yes \\
\hline $\begin{array}{l}\text { Adjusted/Pseudo R-squared } \\
\text { Observations } \\
\text { of which censored at } 0 \\
\text { of which censored at } 100\end{array}$ & $\begin{array}{l}0.583 \\
5,018\end{array}$ & $\begin{array}{l}0.582 \\
5,018\end{array}$ & $\begin{array}{c}0.0901 \\
5,018 \\
196\end{array}$ & $\begin{array}{c}0.0912 \\
5,018 \\
196\end{array}$ & $\begin{array}{c}0.116 \\
5,018 \\
430\end{array}$ & $\begin{array}{c}0.116 \\
5,018 \\
430\end{array}$ & $\begin{array}{c}0.0587 \\
5,018 \\
430 \\
196\end{array}$ & $\begin{array}{c}0.0597 \\
5,018 \\
430 \\
196\end{array}$ \\
\hline
\end{tabular}




\section{Appendix Table 3. SER vs. EER (Cont.)}

\section{Panel C: Orthogonalized Environmental Enforcement; Scope 1 Emissions}

\begin{tabular}{|c|c|c|c|c|}
\hline Dependent variable: & $\begin{array}{c}\ln (1+\text { Global } \\
\text { emissions })\end{array}$ & $\begin{array}{c}\ln (1+\text { Home } \\
\text { emissions })\end{array}$ & $\begin{array}{c}\ln (1+\text { Foreign } \\
\text { emissions })\end{array}$ & $\begin{array}{c}\text { Foreign emissions in } \\
\% \text { of global } \\
\text { emissions }\end{array}$ \\
\hline Specification: & $\begin{array}{c}\text { OLS } \\
(1) \\
\end{array}$ & $\begin{array}{c}\text { Tobit } \\
(2)\end{array}$ & $\begin{array}{c}\text { Tobit } \\
(3)\end{array}$ & $\begin{array}{c}\text { Tobit } \\
(4) \\
\end{array}$ \\
\hline SER (stringency) & $\begin{array}{c}-0.14 * * * \\
(-2.61)\end{array}$ & $\begin{array}{c}-0.27 * * * \\
(-2.75)\end{array}$ & $\begin{array}{l}0.26^{* * *} \\
(2.59)\end{array}$ & $\begin{array}{c}2.84 * * * \\
(2.68)\end{array}$ \\
\hline $\mathrm{EER}_{\mathrm{O}}$ (enforcement; orthogonalized) & $\begin{array}{c}0.01 \\
(0.21)\end{array}$ & $\begin{array}{l}-0.22 * * \\
(-2.27)\end{array}$ & $\begin{array}{l}0.19 * * \\
(1.99)\end{array}$ & $\begin{array}{c}3.44 * * * \\
(3.77)\end{array}$ \\
\hline $\begin{array}{l}\text { Controls } \\
\text { Fixed effects }\end{array}$ & Yes & Yes & Yes & Yes \\
\hline Industry $\times$ Year & Yes & Yes & Yes & Yes \\
\hline $\begin{array}{l}\text { Adjusted/Pseudo R-squared } \\
\text { Observations } \\
\text { of which censored at } 0 \\
\text { of which censored at } 100\end{array}$ & $\begin{array}{l}0.684 \\
4,919\end{array}$ & $\begin{array}{c}0.121 \\
4,919 \\
226\end{array}$ & $\begin{array}{c}0.122 \\
4,919 \\
481\end{array}$ & $\begin{array}{c}0.0578 \\
4,919 \\
481 \\
226\end{array}$ \\
\hline
\end{tabular}

Panel D: Orthogonalized Environmental Enforcement; Scope 2 Emissions

\begin{tabular}{|c|c|c|c|c|}
\hline Dependent variable: & $\begin{array}{c}\ln (1+\text { Global } \\
\text { emissions })\end{array}$ & $\begin{array}{c}\ln (1+\text { Home } \\
\text { emissions })\end{array}$ & $\begin{array}{c}\ln (1+\text { Foreign } \\
\text { emissions })\end{array}$ & $\begin{array}{c}\text { Foreign emissions in } \\
\% \text { of global } \\
\text { emissions } \\
\end{array}$ \\
\hline Specification: & $\begin{array}{l}\text { OLS } \\
\text { (1) }\end{array}$ & $\begin{array}{c}\text { Tobit } \\
\text { (3) }\end{array}$ & $\begin{array}{c}\text { Tobit } \\
\text { (5) }\end{array}$ & $\begin{array}{c}\text { Tobit } \\
(7)\end{array}$ \\
\hline SER (stringency) & $\begin{array}{l}-0.17^{* * *} \\
(-4.36)\end{array}$ & $\begin{array}{l}-0.36^{* * *} \\
(-4.13)\end{array}$ & $\begin{array}{c}0.32^{* * *} \\
(3.54)\end{array}$ & $\begin{array}{c}5.72^{* * *} \\
(5.84)\end{array}$ \\
\hline $\mathrm{EER}_{\mathrm{O}}$ (enforcement; orthogonalized) & $\begin{array}{c}0.00 \\
(0.08)\end{array}$ & $\begin{array}{l}-0.28^{* * *} \\
(-2.64)\end{array}$ & $\begin{array}{c}0.12 \\
(1.53)\end{array}$ & $\begin{array}{c}4.09 * * * \\
(4.18)\end{array}$ \\
\hline $\begin{array}{l}\text { Controls } \\
\text { Fixed effects }\end{array}$ & Yes & Yes & Yes & Yes \\
\hline Industry $\times$ Year & Yes & Yes & Yes & Yes \\
\hline $\begin{array}{l}\text { Adjusted/Pseudo R-squared } \\
\text { Observations } \\
\text { of which censored at } 0 \\
\text { of which censored at } 100\end{array}$ & $\begin{array}{l}0.583 \\
5,018\end{array}$ & $\begin{array}{c}0.0916 \\
5,018 \\
196\end{array}$ & $\begin{array}{c}0.116 \\
5,018 \\
430\end{array}$ & $\begin{array}{c}0.0600 \\
5,018 \\
430 \\
196\end{array}$ \\
\hline
\end{tabular}




\section{Appendix Table 4. Subsample Analysis: Only Externally Audited Emission Data}

The table presents evidence about the relation between emissions in foreign countries and home-country environmental policies for firms whose emissions information is externally verified. Panels A and B show results for Scope 1 and 2 emissions, respectively. Column (1) is estimated with ordinary least squares, and Columns (2) to (4) are estimated as Tobit models. SEER is our proxy for stringency and enforcement of environmental regulation in the firm's home country, with higher values indicating stricter regulation. All regressions include $\ln ($ Assets), Foreign asset share, $\ln (G D P)$, GDP per capita growth, and industry-year fixed effects. Standard errors are clustered by firm. For each independent variable, the top row shows the estimated coefficient and the bottom row shows the $t$-statistic. ***, **, and * indicate significance at the $1 \%, 5 \%$, and $10 \%$ level, respectively.

\section{Panel A: Scope 1 Emissions}

\begin{tabular}{|c|c|c|c|c|}
\hline Dependent variable: & $\begin{array}{l}\ln (1+\text { Global } \\
\text { emissions })\end{array}$ & $\begin{array}{l}\ln (1+\text { Home } \\
\text { emissions })\end{array}$ & $\begin{array}{l}\ln (1+\text { Foreign } \\
\text { emissions })\end{array}$ & $\begin{array}{c}\text { Foreign } \\
\text { emissions in \% } \\
\text { of global } \\
\text { emissions }\end{array}$ \\
\hline Specification: & $\begin{array}{c}\text { OLS } \\
(1)\end{array}$ & $\begin{array}{c}\text { Tobit } \\
(2)\end{array}$ & $\begin{array}{c}\text { Tobit } \\
\text { (3) }\end{array}$ & $\begin{array}{c}\text { Tobit } \\
(4)\end{array}$ \\
\hline SEER & $\begin{array}{l}-0.16^{* *} \\
(-2.32)\end{array}$ & $\begin{array}{c}-0.38 * * * \\
(-3.25)\end{array}$ & $\begin{array}{l}0.26^{* *} \\
(2.23)\end{array}$ & $\begin{array}{l}3.08^{* *} \\
(2.42)\end{array}$ \\
\hline Controls & Yes & Yes & Yes & Yes \\
\hline $\begin{array}{l}\text { Fixed effects } \\
\text { Industry } \times \text { Year }\end{array}$ & Yes & Yes & Yes & Yes \\
\hline $\begin{array}{l}\text { Adjusted/Pseudo R-squared } \\
\text { Observations } \\
\text { of which censored at } 0 \\
\text { of which censored at } 100\end{array}$ & $\begin{array}{l}0.723 \\
3,075\end{array}$ & $\begin{array}{c}0.137 \\
3,075 \\
122\end{array}$ & $\begin{array}{c}0.142 \\
3,075 \\
235\end{array}$ & $\begin{array}{c}0.0614 \\
3,075 \\
235 \\
122 \\
\end{array}$ \\
\hline
\end{tabular}

\section{Panel B: Scope 2 Emissions}

\begin{tabular}{|c|c|c|c|c|}
\hline Dependent variable: & $\begin{array}{c}\ln (1+\text { Global } \\
\text { emissions })\end{array}$ & $\begin{array}{c}\ln (1+\text { Home } \\
\text { emissions) }\end{array}$ & $\begin{array}{c}\ln (1+\text { Foreign } \\
\text { emissions })\end{array}$ & $\begin{array}{c}\text { Foreign } \\
\text { emissions in \% } \\
\text { of global } \\
\text { emissions } \\
\end{array}$ \\
\hline Specification: & $\begin{array}{c}\text { OLS } \\
(1) \\
\end{array}$ & $\begin{array}{c}\text { Tobit } \\
(2)\end{array}$ & $\begin{array}{c}\text { Tobit } \\
(3)\end{array}$ & $\begin{array}{c}\text { Tobit } \\
(4) \\
\end{array}$ \\
\hline SEER & $\begin{array}{c}-0.15^{* * *} \\
(-3.03)\end{array}$ & $\begin{array}{c}-0.42 * * * \\
(-3.61)\end{array}$ & $\begin{array}{c}0.31^{* * *} \\
(2.94)\end{array}$ & $\begin{array}{c}6.07 * * * \\
(4.84)\end{array}$ \\
\hline $\begin{array}{l}\text { Controls } \\
\text { Fixed effects }\end{array}$ & Yes & Yes & Yes & Yes \\
\hline Industry $\times$ Year & Yes & Yes & Yes & Yes \\
\hline $\begin{array}{l}\text { Adjusted/Pseudo R-squared } \\
\text { Observations } \\
\text { of which censored at } 0 \\
\text { of which censored at } 100\end{array}$ & $\begin{array}{l}0.608 \\
2,895\end{array}$ & $\begin{array}{c}0.0852 \\
2,895 \\
115\end{array}$ & $\begin{array}{c}0.137 \\
2,895 \\
168\end{array}$ & $\begin{array}{c}0.0653 \\
2,895 \\
168 \\
115 \\
\end{array}$ \\
\hline
\end{tabular}




\section{Appendix Table 5. Firm-Level Emissions: Controlling for Comparative Advantage}

The table replicates Table 3 and adds control variables for the comparative advantage of the home country. Panels A and B show results for Scope 1 and 2 emissions, respectively. Columns (1) and (2) are estimated with ordinary least squares, and Columns (3) to (8) are estimated as Tobit models. SEER is our proxy for stringency and enforcement of environmental regulation in the firm's home country, with higher values indicating stricter regulation. CA(Skill) and CA(Capital) are our additional controls for comparative advantage in skilled labor and capital of the firm's industry in the home country, respectively. All regressions include industryyear fixed effects. Standard errors are clustered by firm. For each independent variable, the top row shows the estimated coefficient and the bottom row shows the $t$-statistic. $* * *, * *$, and * indicate significance at the $1 \%, 5 \%$, and $10 \%$ level, respectively.

\section{Panel A: Scope 1 Emissions}

\begin{tabular}{|c|c|c|c|c|c|c|c|c|}
\hline \multirow{2}{*}{$\begin{array}{l}\text { Dependent variable: } \\
\text { Specification: }\end{array}$} & \multicolumn{2}{|c|}{$\ln (1+$ Global emissions $)$} & \multicolumn{2}{|c|}{$\ln (1+$ Home emissions $)$} & \multicolumn{2}{|c|}{$\ln (1+$ Foreign emissions $)$} & \multicolumn{2}{|c|}{$\begin{array}{c}\text { Foreign emissions in \% } \\
\text { of global emissions }\end{array}$} \\
\hline & $\begin{array}{c}\text { OLS } \\
(1)\end{array}$ & $\begin{array}{l}\text { OLS } \\
(2)\end{array}$ & $\begin{array}{c}\text { Tobit } \\
\text { (3) }\end{array}$ & $\begin{array}{c}\text { Tobit } \\
(4)\end{array}$ & $\begin{array}{c}\text { Tobit } \\
(5)\end{array}$ & $\begin{array}{c}\text { Tobit } \\
(6)\end{array}$ & $\begin{array}{c}\text { Tobit } \\
(7)\end{array}$ & $\begin{array}{c}\text { Tobit } \\
(8)\end{array}$ \\
\hline SEER & $\begin{array}{l}-0.13^{*} \\
(-1.72)\end{array}$ & $\begin{array}{c}-0.08 \\
(-1.04)\end{array}$ & $\begin{array}{l}-0.26 * * \\
(-2.14)\end{array}$ & $\begin{array}{c}-0.17 \\
(-1.22)\end{array}$ & $\begin{array}{c}0.38 * * * \\
(2.90)\end{array}$ & $\begin{array}{l}0.28 * * \\
(2.00)\end{array}$ & $\begin{array}{l}3.59 * * \\
(2.47)\end{array}$ & $\begin{array}{c}2.27 \\
(1.51)\end{array}$ \\
\hline \multicolumn{9}{|l|}{ Firm characteristics } \\
\hline $\ln$ (Assets) & $\begin{array}{l}1.15 * * * \\
(21.99)\end{array}$ & $\begin{array}{l}1.14 * * * \\
(22.39)\end{array}$ & $\begin{array}{l}0.96 * * * \\
(10.28)\end{array}$ & $\begin{array}{c}0.99 * * * \\
(10.22)\end{array}$ & $\begin{array}{l}1.51 * * * \\
(17.36)\end{array}$ & $\begin{array}{l}1.44 * * * \\
(17.23)\end{array}$ & $\begin{array}{c}3.12 * * * \\
(2.91)\end{array}$ & $\begin{array}{l}1.77^{*} \\
(1.74)\end{array}$ \\
\hline Foreign asset share & & $\begin{array}{l}0.00 * \\
(1.66)\end{array}$ & & $\begin{array}{c}-0.02 * * * \\
(-2.69)\end{array}$ & & $\begin{array}{c}0.03^{* * *} \\
(6.12)\end{array}$ & & $\begin{array}{c}0.48^{* * *} \\
(8.53)\end{array}$ \\
\hline \multicolumn{9}{|l|}{ Home country characteristics } \\
\hline $\ln (G D P)$ & $\begin{array}{l}0.16 * * \\
(2.43)\end{array}$ & $\begin{array}{l}0.16^{* *} \\
(2.30)\end{array}$ & $\begin{array}{c}0.92 * * * \\
(7.38)\end{array}$ & $\begin{array}{c}0.88 * * * \\
(6.34)\end{array}$ & $\begin{array}{c}-0.41 * * * \\
(-3.57)\end{array}$ & $\begin{array}{l}-0.21^{*} \\
(-1.82)\end{array}$ & $\begin{array}{c}-12.79 * * * \\
(-9.70)\end{array}$ & $\begin{array}{c}-10.54 * * * \\
(-7.51)\end{array}$ \\
\hline GDP per capita growth & $\begin{array}{c}0.00 \\
(0.23)\end{array}$ & $\begin{array}{l}-0.00 \\
(-0.14)\end{array}$ & $\begin{array}{c}0.00 \\
(0.09)\end{array}$ & $\begin{array}{l}-0.00 \\
(-0.10)\end{array}$ & $\begin{array}{c}-0.19 * * * \\
(-3.58)\end{array}$ & $\begin{array}{c}-0.14 * * * \\
(-2.84)\end{array}$ & $\begin{array}{c}-1.70 * * * \\
(-3.34)\end{array}$ & $\begin{array}{c}-1.30 * * * \\
(-2.72)\end{array}$ \\
\hline CA(Skill) & $\begin{array}{c}-0.93 * * * \\
(-5.20)\end{array}$ & $\begin{array}{c}-0.85 * * * \\
(-4.37)\end{array}$ & $\begin{array}{c}-1.72 * * * \\
(-7.24)\end{array}$ & $\begin{array}{c}-1.76 * * * \\
(-6.64)\end{array}$ & $\begin{array}{c}0.31 \\
(0.90)\end{array}$ & $\begin{array}{c}0.13 \\
(0.39)\end{array}$ & $\begin{array}{c}14.79 * * * \\
(4.57)\end{array}$ & $\begin{array}{c}14.77 * * * \\
(4.57)\end{array}$ \\
\hline CA(Capital) & $\begin{array}{c}0.01 \\
(1.35)\end{array}$ & $\begin{array}{c}0.01 \\
(0.72)\end{array}$ & $\begin{array}{c}0.01 \\
(0.45)\end{array}$ & $\begin{array}{c}-0.00 \\
(-0.22)\end{array}$ & $\begin{array}{c}0.03 \\
(1.62)\end{array}$ & $\begin{array}{c}0.01 \\
(0.96)\end{array}$ & $\begin{array}{c}0.21 \\
(1.25)\end{array}$ & $\begin{array}{c}0.20 \\
(1.18)\end{array}$ \\
\hline Fixed effects & & & & & & & & \\
\hline Industry $\times$ Year & Yes & Yes & Yes & Yes & Yes & Yes & Yes & Yes \\
\hline $\begin{array}{l}\text { Adjusted/Pseudo R-squared } \\
\text { Observations } \\
\text { of which censored at } 0\end{array}$ & $\begin{array}{l}0.630 \\
2,939\end{array}$ & $\begin{array}{l}0.625 \\
2,344\end{array}$ & $\begin{array}{c}0.107 \\
2,939 \\
105\end{array}$ & $\begin{array}{c}0.110 \\
2,344 \\
91\end{array}$ & $\begin{array}{c}0.0858 \\
2,939 \\
200\end{array}$ & $\begin{array}{c}0.105 \\
2,344 \\
127\end{array}$ & $\begin{array}{c}0.0295 \\
2,939 \\
200\end{array}$ & $\begin{array}{c}0.0428 \\
2,344 \\
127\end{array}$ \\
\hline of which censored at 100 & & & & & & & 105 & 91 \\
\hline
\end{tabular}




\section{Appendix Table 5. Firm-Level Emissions: Controlling for Comparative Advantage (Cont.)}

\section{Panel B: Scope 2 Emissions}

\begin{tabular}{|c|c|c|c|c|c|c|c|c|}
\hline \multirow{2}{*}{$\begin{array}{l}\text { Dependent variable: } \\
\text { Specification: }\end{array}$} & \multicolumn{2}{|c|}{$\ln (1+$ Global emissions $)$} & \multicolumn{2}{|c|}{$\ln (1+$ Home emissions $)$} & \multicolumn{2}{|c|}{$\ln (1+$ Foreign emissions $)$} & \multicolumn{2}{|c|}{$\begin{array}{c}\text { Foreign emissions in \% } \\
\text { of global emissions }\end{array}$} \\
\hline & $\begin{array}{c}\text { OLS } \\
(1) \\
\end{array}$ & $\begin{array}{c}\text { OLS } \\
(2) \\
\end{array}$ & $\begin{array}{c}\text { Tobit } \\
\text { (3) }\end{array}$ & $\begin{array}{c}\text { Tobit } \\
(4) \\
\end{array}$ & $\begin{array}{c}\text { Tobit } \\
(5) \\
\end{array}$ & $\begin{array}{c}\text { Tobit } \\
(6)\end{array}$ & $\begin{array}{c}\text { Tobit } \\
(7) \\
\end{array}$ & $\begin{array}{c}\text { Tobit } \\
(8) \\
\end{array}$ \\
\hline SEER & $\begin{array}{l}-0.17 * * \\
(-2.25)\end{array}$ & $\begin{array}{c}-0.12 \\
(-1.47)\end{array}$ & $\begin{array}{c}-0.33 * * * \\
(-2.68)\end{array}$ & $\begin{array}{l}-0.24^{*} \\
(-1.79)\end{array}$ & $\begin{array}{c}0.39 * * * \\
(2.95)\end{array}$ & $\begin{array}{l}0.31^{* *} \\
(2.10)\end{array}$ & $\begin{array}{c}4.13 * * * \\
(2.81)\end{array}$ & $\begin{array}{l}2.93^{*} \\
(1.91)\end{array}$ \\
\hline \multicolumn{9}{|l|}{ Firm characteristics } \\
\hline $\ln$ (Assets) & $\begin{array}{l}1.14^{* * *} \\
(21.87)\end{array}$ & $\begin{array}{l}1.15^{* * *} \\
(22.11)\end{array}$ & $\begin{array}{l}0.94 * * * \\
(9.82)\end{array}$ & $\begin{array}{c}0.99 * * * \\
(9.87)\end{array}$ & $\begin{array}{l}1.52 * * * \\
(16.95)\end{array}$ & $\begin{array}{l}1.46 * * * \\
(16.71)\end{array}$ & $\begin{array}{l}3.38 * * * \\
(3.06)\end{array}$ & $\begin{array}{l}1.96^{*} \\
(1.87)\end{array}$ \\
\hline Foreign asset share & & $\begin{array}{c}0.00 \\
(1.21)\end{array}$ & & $\begin{array}{c}-0.02 * * \\
(-2.56)\end{array}$ & & $\begin{array}{c}0.03 * * * \\
(5.67)\end{array}$ & & $\begin{array}{c}0.49 * * * \\
(8.46)\end{array}$ \\
\hline \multicolumn{9}{|l|}{ Home country characteristics } \\
\hline $\ln (G D P)$ & $\begin{array}{l}0.15 * * \\
(2.18)\end{array}$ & $\begin{array}{l}0.15^{* *} \\
(2.00)\end{array}$ & $\begin{array}{c}0.92 * * * \\
(7.34)\end{array}$ & $\begin{array}{c}0.89 * * * \\
(6.41)\end{array}$ & $\begin{array}{c}-0.41 * * * \\
(-3.45)\end{array}$ & $\begin{array}{l}-0.23^{*} \\
(-1.86)\end{array}$ & $\begin{array}{c}-13.06^{* * *} \\
(-9.84)\end{array}$ & $\begin{array}{c}-10.92 * * * \\
(-7.77)\end{array}$ \\
\hline GDP per capita growth & $\begin{array}{c}0.00 \\
(0.03)\end{array}$ & $\begin{array}{c}-0.01 \\
(-0.37)\end{array}$ & $\begin{array}{c}-0.01 \\
(-0.12)\end{array}$ & $\begin{array}{c}-0.02 \\
(-0.33)\end{array}$ & $\begin{array}{c}-0.20 * * * \\
(-3.75)\end{array}$ & $\begin{array}{c}-0.15^{* * *} \\
(-2.87)\end{array}$ & $\begin{array}{c}-1.72 * * * \\
(-3.23)\end{array}$ & $\begin{array}{c}-1.26 * * * \\
(-2.59)\end{array}$ \\
\hline CA(Skill) & $\begin{array}{c}-0.88 * * * \\
(-4.78)\end{array}$ & $\begin{array}{c}-0.79 * * * \\
(-3.92)\end{array}$ & $\begin{array}{c}-1.72 * * * \\
(-7.07)\end{array}$ & $\begin{array}{c}-1.77 * * * \\
(-6.52)\end{array}$ & $\begin{array}{c}0.33 \\
(0.97)\end{array}$ & $\begin{array}{c}0.23 \\
(0.65)\end{array}$ & $\begin{array}{c}15.37 * * * \\
(4.76)\end{array}$ & $\begin{array}{c}15.97 * * * \\
(5.02)\end{array}$ \\
\hline CA(Capital) & $\begin{array}{c}0.01 \\
(1.20)\end{array}$ & $\begin{array}{c}0.01 \\
(0.63)\end{array}$ & $\begin{array}{c}0.00 \\
(0.21)\end{array}$ & $\begin{array}{c}-0.01 \\
(-0.51)\end{array}$ & $\begin{array}{l}0.03^{*} \\
(1.90)\end{array}$ & $\begin{array}{c}0.02 \\
(1.29)\end{array}$ & $\begin{array}{c}0.26 \\
(1.58)\end{array}$ & $\begin{array}{c}0.27 \\
(1.58)\end{array}$ \\
\hline \multicolumn{9}{|l|}{ Fixed effects } \\
\hline Industry $\times$ Year & Yes & Yes & Yes & Yes & Yes & Yes & Yes & Yes \\
\hline $\begin{array}{l}\text { Adjusted/Pseudo R-squared } \\
\text { Observations } \\
\text { of which censored at } 0 \\
\text { of which censored at } 100\end{array}$ & $\begin{array}{l}0.626 \\
2,752\end{array}$ & $\begin{array}{l}0.623 \\
2,185\end{array}$ & $\begin{array}{l}0.108 \\
2,752 \\
95\end{array}$ & $\begin{array}{c}0.113 \\
2,185 \\
83\end{array}$ & $\begin{array}{c}0.0867 \\
2,752 \\
189\end{array}$ & $\begin{array}{c}0.103 \\
2,185 \\
122\end{array}$ & $\begin{array}{c}0.0308 \\
2,752 \\
189 \\
95\end{array}$ & $\begin{array}{c}0.0449 \\
2,185 \\
122 \\
83 \\
\end{array}$ \\
\hline
\end{tabular}




\section{Appendix Table 6. Firm-Country-Level Emissions: Controlling for Comparative Advantage}

The table replicates Table 4 and adds control variables for the comparative advantage of the home and foreign countries. Panels A and B show results for Scope 1 and 2 emissions, respectively. Regressions are estimated as Tobit regressions. $S E E R_{\text {home }}-S_{\text {SER }}$ foreign is our proxy for stringency and enforcement of environmental regulation in the home minus the foreign country, with higher values indicating stricter regulation at home. CA(Skill) and CA(Capital) are our additional controls for comparative advantage in skilled labor and capital, respectively of the firm's industry in the home or foreign country. All regressions include home country and foreign country fixed effects. Standard errors clustered by country-pair. For each independent variable, the top row shows the estimated coefficient and the bottom row shows the $t$-statistic. ${ }^{* * *},{ }^{* *}$, and * indicate significance at the $1 \%, 5 \%$, and $10 \%$ level, respectively.

\begin{tabular}{|c|c|c|c|c|}
\hline \multirow[b]{2}{*}{ Dependent variable: } & \multicolumn{2}{|c|}{ Scope 1 emissions } & \multicolumn{2}{|c|}{ Scope 2 emissions } \\
\hline & $\begin{array}{c}\ln (1+\text { Foreign } \\
\text { emissions })\end{array}$ & $\begin{array}{c}\text { Foreign } \\
\text { emissions } \\
\text { in \% of global } \\
\text { emissions } \\
\end{array}$ & $\begin{array}{c}\ln (1+\text { Foreign } \\
\text { emissions })\end{array}$ & $\begin{array}{c}\text { Foreign } \\
\text { emissions } \\
\text { in } \% \text { of global } \\
\text { emissions }\end{array}$ \\
\hline Specification: & $\begin{array}{c}\text { Tobit } \\
(1)\end{array}$ & $\begin{array}{c}\text { Tobit } \\
(2)\end{array}$ & $\begin{array}{c}\text { Tobit } \\
(3)\end{array}$ & $\begin{array}{c}\text { Tobit } \\
(4)\end{array}$ \\
\hline $\mathrm{SEER}_{\text {home }}-\mathrm{SEER}_{\text {foreign }}$ & $\begin{array}{c}0.88^{* * *} \\
(5.24)\end{array}$ & $\begin{array}{c}0.92^{* * *} \\
(4.77)\end{array}$ & $\begin{array}{c}0.99 * * * \\
(6.41)\end{array}$ & $\begin{array}{c}0.94^{* * *} \\
(5.30)\end{array}$ \\
\hline Firm characteristics & & & & \\
\hline $\ln$ (Assets) & $\begin{array}{l}2.39 * * * \\
(30.87)\end{array}$ & $\begin{array}{l}1.81^{* * *} \\
(16.06)\end{array}$ & $\begin{array}{c}2.00 * * * \\
(28.12)\end{array}$ & $\begin{array}{l}1.58^{* * *} \\
(14.37)\end{array}$ \\
\hline Foreign asset share & $\begin{array}{l}0.04^{* * *} \\
(10.52)\end{array}$ & $\begin{array}{c}0.04^{* * * *} \\
(8.90)\end{array}$ & $\begin{array}{c}0.03 * * * \\
(9.68)\end{array}$ & $\begin{array}{c}0.04^{* * *} \\
(7.65)\end{array}$ \\
\hline Foreign country characteris & & & & \\
\hline $\ln (\mathrm{GDP})$ & $\begin{array}{c}0.55 \\
(1.41)\end{array}$ & $\begin{array}{c}0.92 * * \\
(2.05)\end{array}$ & $\begin{array}{l}0.94 * * \\
(2.40)\end{array}$ & $\begin{array}{c}1.58^{* * *} \\
(3.12)\end{array}$ \\
\hline CA(Skill) & $\begin{array}{c}1.49 * * * \\
(2.90)\end{array}$ & $\begin{array}{c}2.23^{* * * *} \\
(2.93)\end{array}$ & $\begin{array}{l}1.24 * * \\
(2.37)\end{array}$ & $\begin{array}{l}1.47^{*} \\
(1.78)\end{array}$ \\
\hline CA(Capital) & $\begin{array}{c}-0.24 \\
(-1.47)\end{array}$ & $\begin{array}{c}-0.36 * * \\
(-1.99)\end{array}$ & $\begin{array}{l}-0.21 \\
(-1.56)\end{array}$ & $\begin{array}{c}-0.38 * * \\
(-2.47)\end{array}$ \\
\hline Home country characteristic & & & & \\
\hline CA(Skill) & $\begin{array}{c}-2.03 * * * \\
(-4.62)\end{array}$ & $\begin{array}{c}-1.69 * * * \\
(-3.29)\end{array}$ & $\begin{array}{c}-1.23 * * * \\
(-2.71)\end{array}$ & $\begin{array}{c}-0.72 \\
(-1.39)\end{array}$ \\
\hline CA(Capital) & $\begin{array}{c}0.19 \\
(1.25)\end{array}$ & $\begin{array}{l}0.31^{*} \\
(1.81)\end{array}$ & $\begin{array}{l}0.23^{*} \\
(1.74)\end{array}$ & $\begin{array}{c}0.39 * * * \\
(2.64)\end{array}$ \\
\hline Country pair characteristics & & & & \\
\hline ln(Geographic distance) & $\begin{array}{c}-1.25 * * * \\
(-3.83)\end{array}$ & $\begin{array}{c}-1.38 * * * \\
(-3.38)\end{array}$ & $\begin{array}{c}-1.25^{* * *} \\
(-4.01)\end{array}$ & $\begin{array}{c}-1.52 * * * \\
(-3.40)\end{array}$ \\
\hline Common border & $\begin{array}{c}-0.16 \\
(-0.22)\end{array}$ & $\begin{array}{c}1.00 \\
(1.06)\end{array}$ & $\begin{array}{c}-0.77 \\
(-1.14)\end{array}$ & $\begin{array}{c}0.21 \\
(0.21)\end{array}$ \\
\hline Common colonial history & $\begin{array}{c}1.91 * * * \\
(3.76)\end{array}$ & $\begin{array}{c}2.87^{* * *} \\
(3.17)\end{array}$ & $\begin{array}{c}1.74 * * * \\
(3.97)\end{array}$ & $\begin{array}{c}3.14^{* * *} \\
(2.88)\end{array}$ \\
\hline $\ln$ (Trade) & $\begin{array}{c}1.65^{* * * *} \\
(7.95)\end{array}$ & $\begin{array}{c}1.73^{* * *} \\
(7.01)\end{array}$ & $\begin{array}{c}1.68^{* * *} \\
(8.11)\end{array}$ & $\begin{array}{c}1.80^{* * *} \\
(6.85)\end{array}$ \\
\hline Fixed effects & & & & \\
\hline Foreign country & Yes & Yes & Yes & Yes \\
\hline Home country & Yes & Yes & Yes & Yes \\
\hline Pseudo R-squared & 0.196 & 0.180 & 0.192 & 0.182 \\
\hline Observations & 274,474 & 274,474 & 275,293 & 275,293 \\
\hline of which censored at 0 & 253,191 & 253,191 & 251,345 & 251,345 \\
\hline of which uncensored & 21,283 & 21,280 & 23,948 & 23,945 \\
\hline of which censored at 100 & & 3 & & 3 \\
\hline
\end{tabular}




\section{Figure 1. Global Development of Environmental Regulation}

The heat maps show our proxy for environmental regulation (SEER) for the 150 countries included in our sample as of 2008 in Panel A and 2015 in Panel B. SEER combines the World Economic Forum's assessment of a country's stringency and enforcement of environmental regulation. SEER ranges from 0.14 to 7 , with lower values, colored red, indicating laxer environmental regulation and higher values, colored green, indicating stricter environmental regulation.

Panel A. 2008

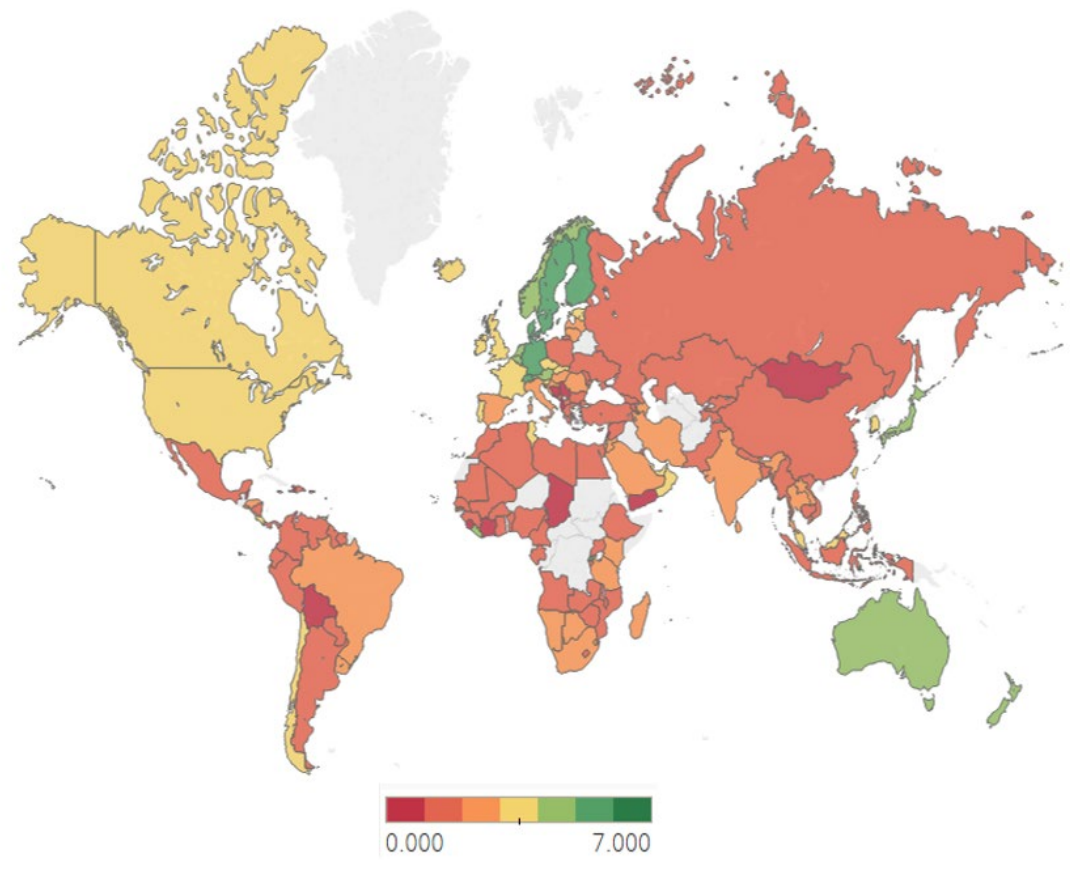

Panel B. 2015

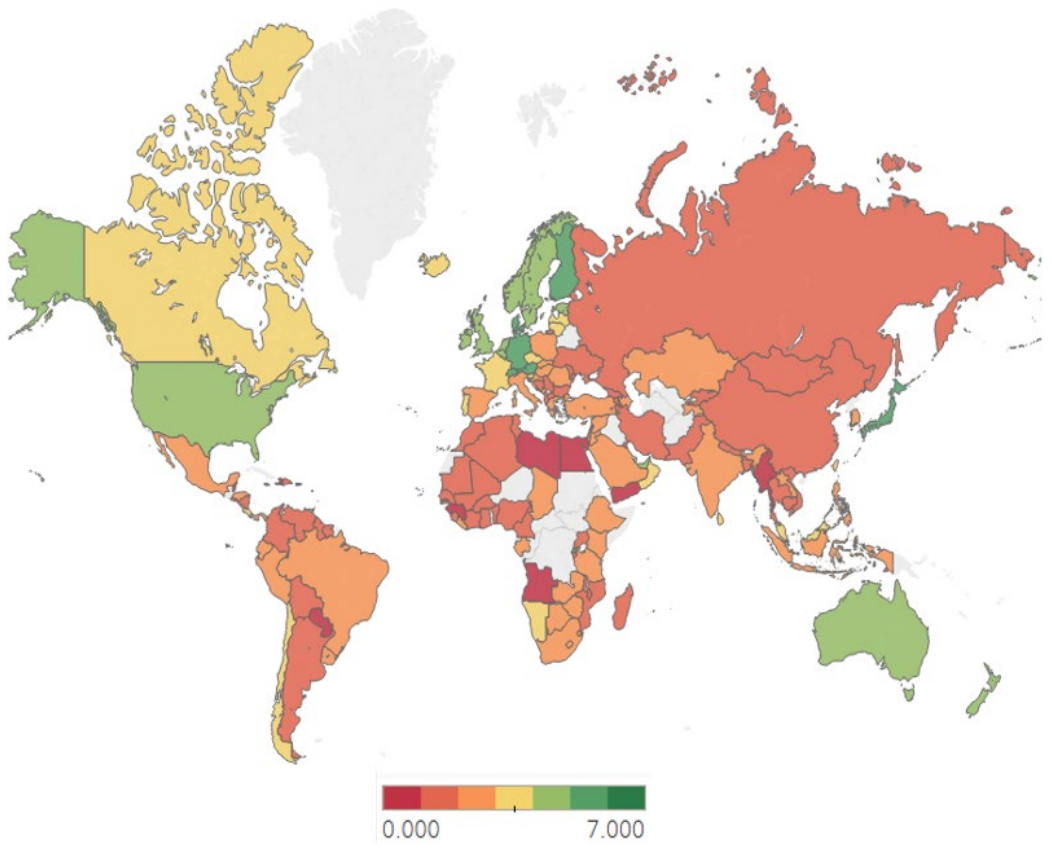




\section{Figure 2. Evolution of Pollution Over Time 2008-2015}

This figure shows the annual changes in $\mathrm{CO}_{2}$ emissions by firms in our sample over the period of 2008-2015. The sample includes the firm-country-year observations for which SEER in the home and foreign country is known. We plot the point estimates and 95\% confidence intervals of the year dummy variables from the ordinary least squares regressions, where the dependent variable is $\ln (1+$ Global emissions $)$ and foreign emissions as a percentage of global emissions in Panel A and $\ln (1+$ Home emissions $)$ and $\ln (1+$ Foreign emissions $)$ in Panel B. All regressions include firm fixed effects. The dependent variables are based on Scope 1 emissions. The coefficients of the year dummy variables indicate the incremental changes in pollution activities over time (2008 as a baseline).

\section{Panel A. Global Emissions and Percentage of Foreign Emissions}

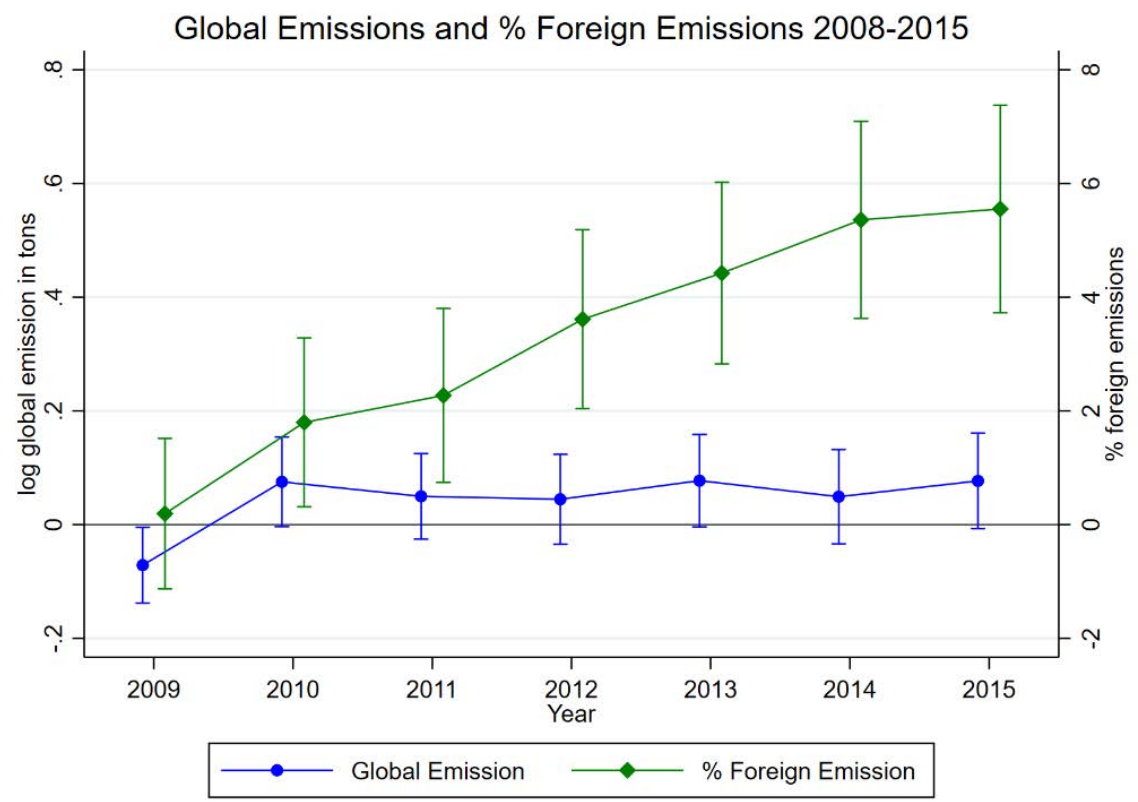

\section{Panel B. Domestic versus Foreign Emissions}

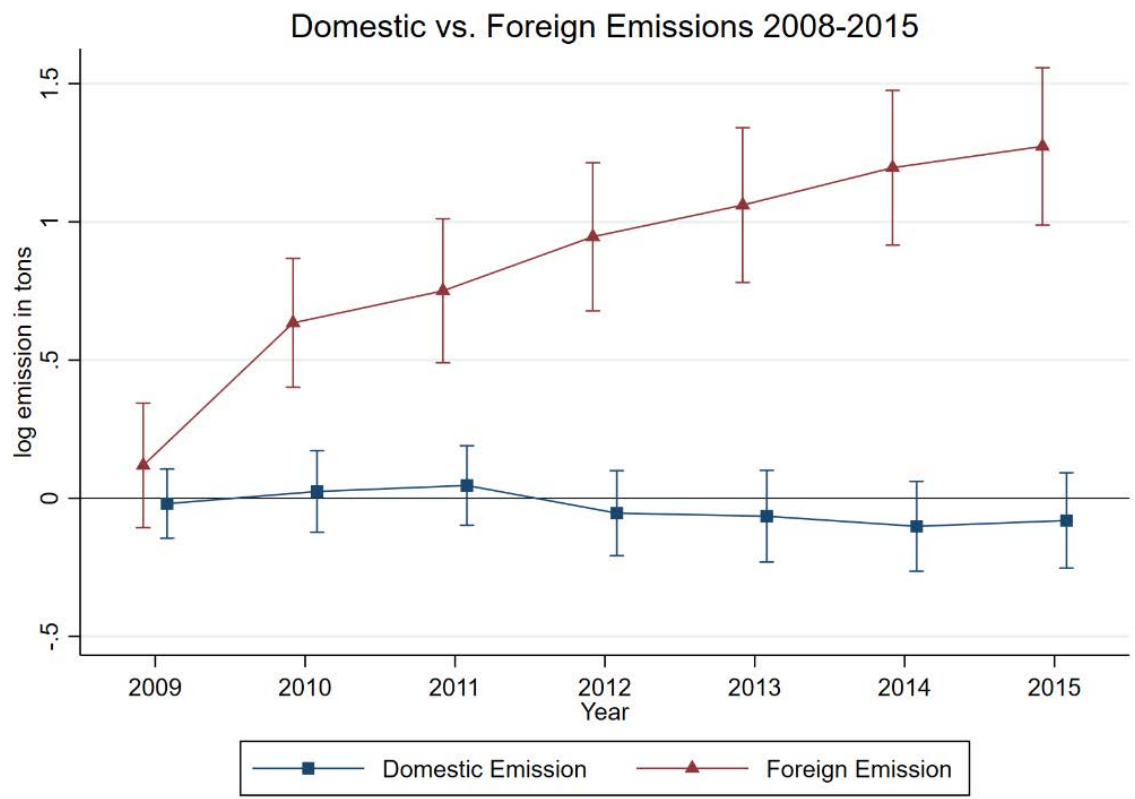




\section{Figure 3. Visualization of the Home and Foreign Emissions with Respect to Cross-Country Environmental Regulation}

The figure visualizes the relation between country-level environmental regulation and $\mathrm{CO}_{2}$ emissions by multinational firms. We plot each country as a circle, with the size indicating the average home emissions amount (in tons) by multinational firms headquartered in that country. The color of the circle represents the score of environmental regulation of each country, measured as SEER, a country's stringency and enforcement of environmental regulation. SEER ranges from 0.14 to 7 , with red being lower values indicating laxer environmental regulation and green being higher values indicating stricter environmental regulation. The average percentage of $\mathrm{CO}_{2}$ emissions in foreign countries out of global emissions by the multinational firms headquartered in each country are shown on the $y$-axis. All numbers are averaged by firms over the 2008-2015 period.

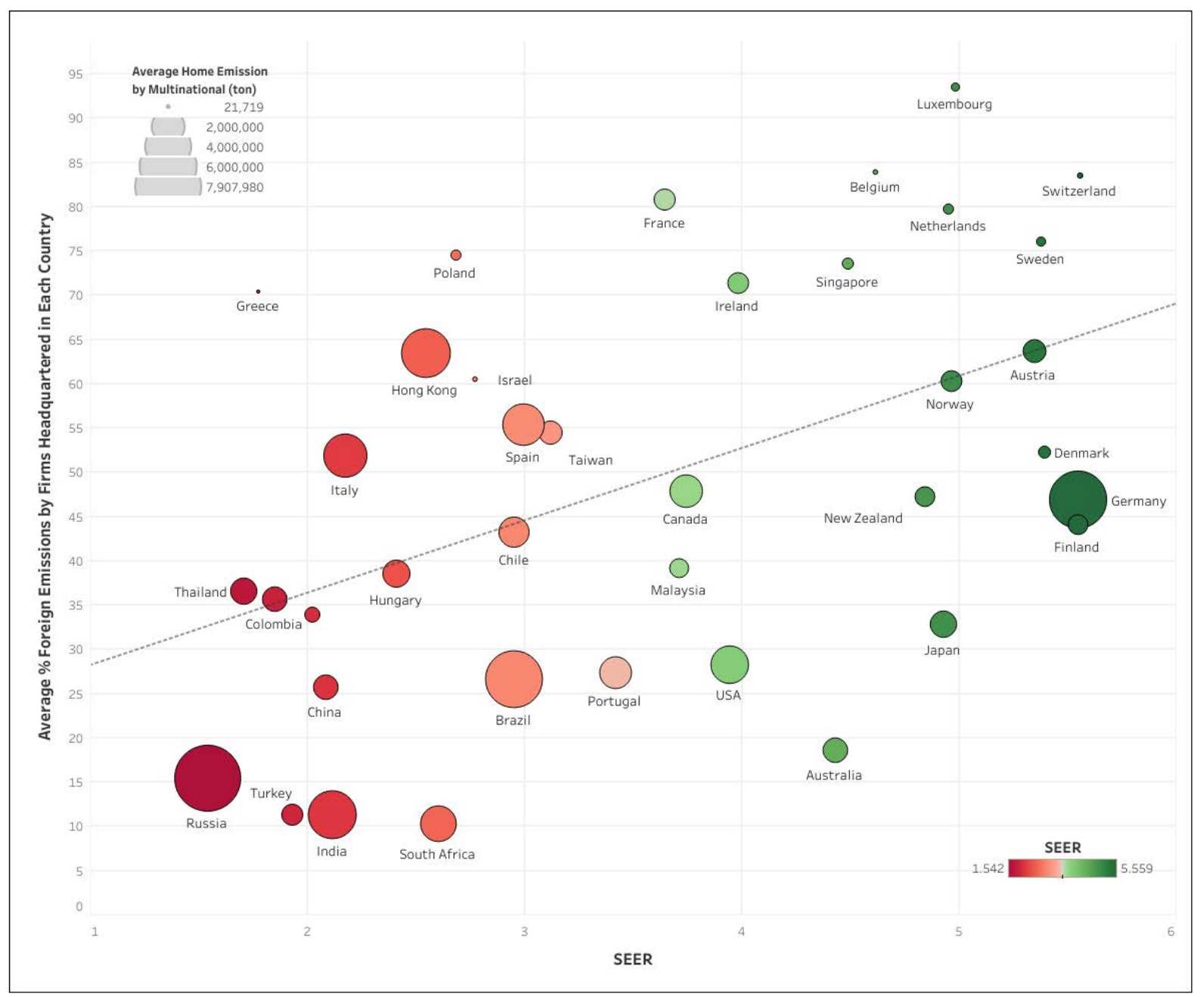




\section{Figure 4. Differences in Environmental Regulation and Emissions in Foreign Countries}

The figure presents the differences in environmental regulation and emissions in foreign countries. The sample includes the firm-country-year observations for which SEER in the home and foreign country is known. We exclude the observations with zero emissions. We split the firm-country pairs into three categories based on the difference in environmental regulation in the home versus foreign country. The left, middle, right bar panels on the $x$-axis represent country pairs with stronger $\left(\operatorname{SEER}_{\text {home }}-\mathrm{SEER}_{\text {foreign }}<-1\right)$, similar $\left(-1 \leq \mathrm{SEER}_{\text {home }}-\mathrm{SEER}_{\text {foreign }}<1\right)$, and weaker $\left(\mathrm{SEER}_{\text {home }}-\mathrm{SEER}_{\text {foreign }} \geq 1\right)$ regulation abroad relative to the home country. The $y$-axis shows average tons of $\mathrm{CO}_{2}$ emissions to a target foreign country by the multinational firms headquartered in the home country per million USD of the foreign country's GDP.

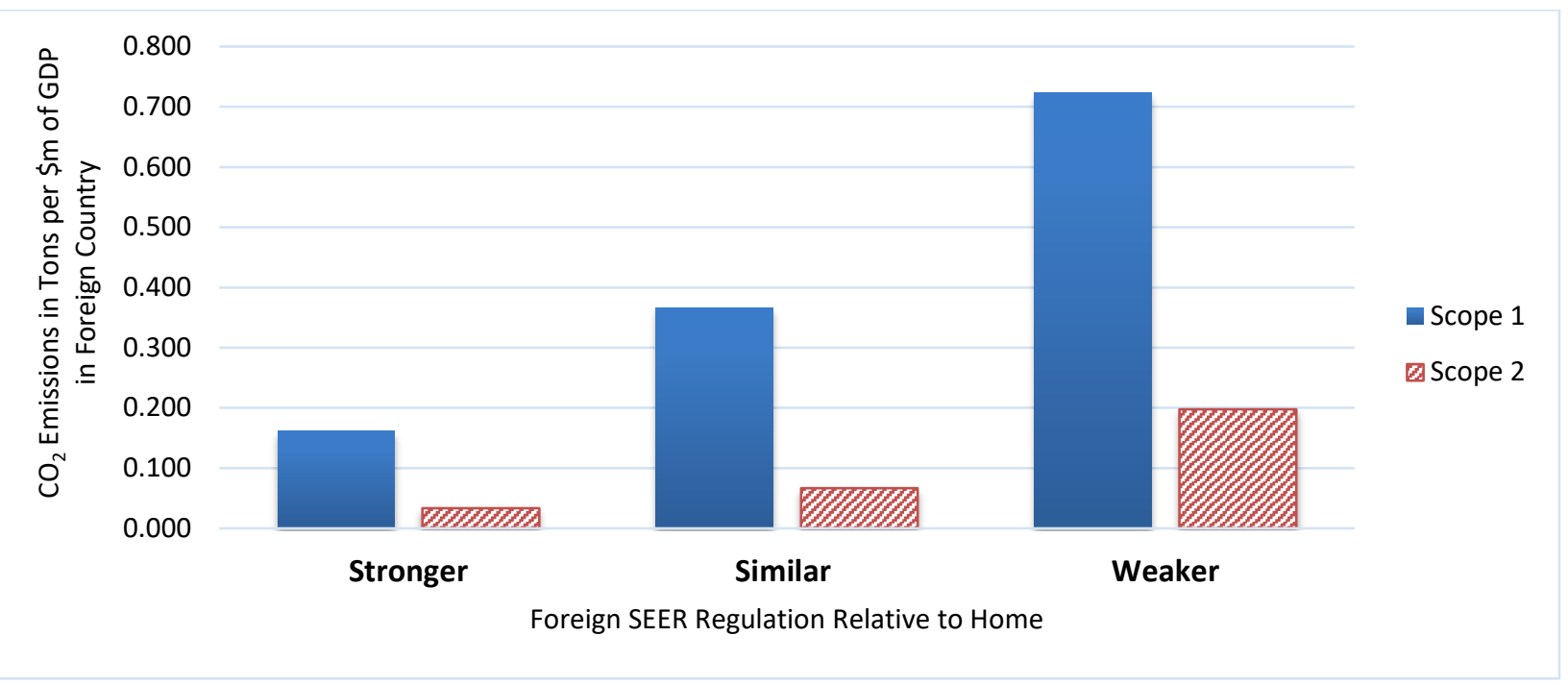




\section{Figure 5. Pollution Intensity by Industry}

This chart shows the $\mathrm{CO}_{2}$ intensity of various industries in the European Union (2018 member states). $\mathrm{CO}_{2}$ intensity is measured as the kilograms of $\mathrm{CO}_{2}$ per euro of gross value added. For comparability over time, gross value added is measured in real terms (chain linked volumes at 2010 prices) to eliminate the effects of inflation. Pollution-intensive industries are marked with striped red bars. Source: Eurostat, Air emission accounts, Air emissions intensities by NACE Rev. 2 activity (env_ac_aeint_r2): http://ec.europa.eu/eurostat/web/environment/emissions-of-greenhousegases-and-air-pollutants/air-emission-accounts/database

\section{$\mathrm{CO}_{2}$ Intensity (kg of $\mathrm{CO}_{2}$ per Euro of Gross Value Added)}

D - Electricity, gas, steam and air conditioning supply C19 - Manufacture of coke and refined petroleum products H51 - Air transport H50 - Water transport C23 - Manufacture of other non-metallic mineral products C24 - Manufacture of basic metals

C22-C23 - Manufacture of rubber and plastic products and. C20 - Manufacture of chemicals and chemical products A03 - Fishing and aquaculture C17 - Manufacture of paper and paper products H49 - Land transport and transport via pipelines

A01 - Crop and animal production, hunting and related.

$$
\mathrm{B} \text { - Mining and quarrying }
$$

E37-E39 - Sewerage, waste management, remediation activities

C10-C12 - Manufacture of food products; beverages and.

C16 - Manufacture of wood and of products of wood and.

A02 - Forestry and logging

E36 - Water collection, treatment and supply

C22 - Manufacture of rubber and plastic products

C13-C15 - Manufacture of textiles, wearing apparel, leather.

H52 - Warehousing and support activities for transportation

H53 - Postal and courier activities

N77 - Rental and leasing activities

C25 - Manufacture of fabricated metal products, except...

C18 - Printing and reproduction of recorded media I

C31+C32 - Manufacture of furniture; other manufacturing I

$$
\text { F - Construction I }
$$

C21 - Manufacture of basic pharmaceutical products and...

R93 - Sports activities and amusement and recreation activities I

C29 - Manufacture of motor vehicles, trailers and semi-trailers

G45 - Wholesale and retail trade and repair of motor vehicles...

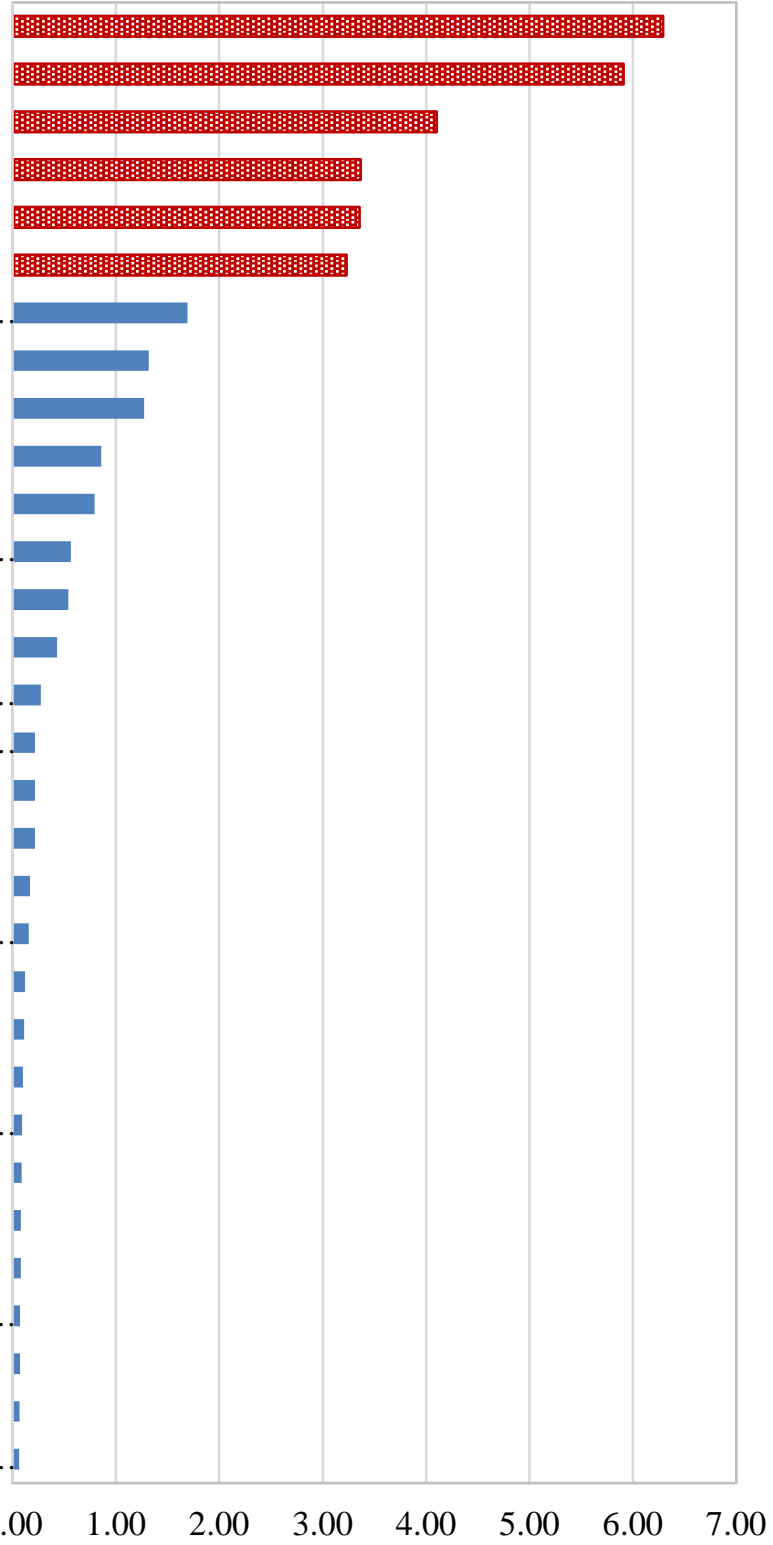

